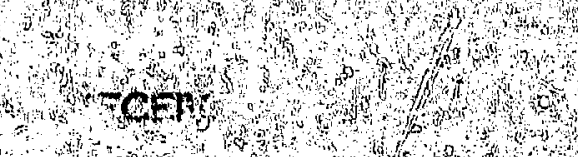

\title{
UCR1 1570.6
}

\section{P. 0.3812003}

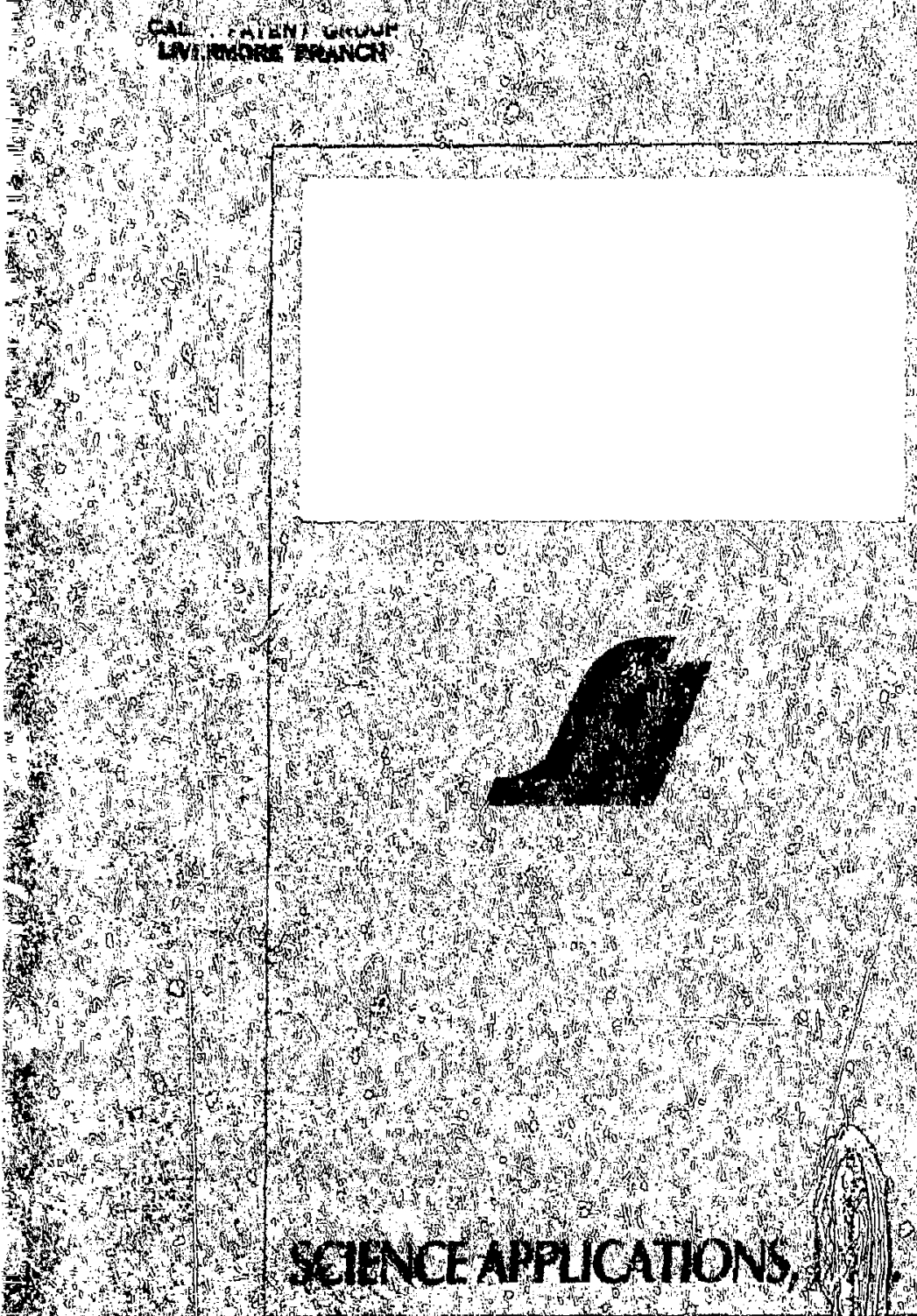

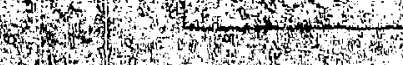

$\begin{array}{llll}3 & & \\ 3\end{array}$ 


\title{
FINAL REPORT ON THE \\ CLASSIFICATION OF
}

RADIOACTIVE WASTES

Report No. SAI 76-649-WA

\author{
Prepared Eor \\ University of California \\ Lawrence Livermore Laboratory \\ Contract No. P.O. $3812 \mathrm{bos}$
}
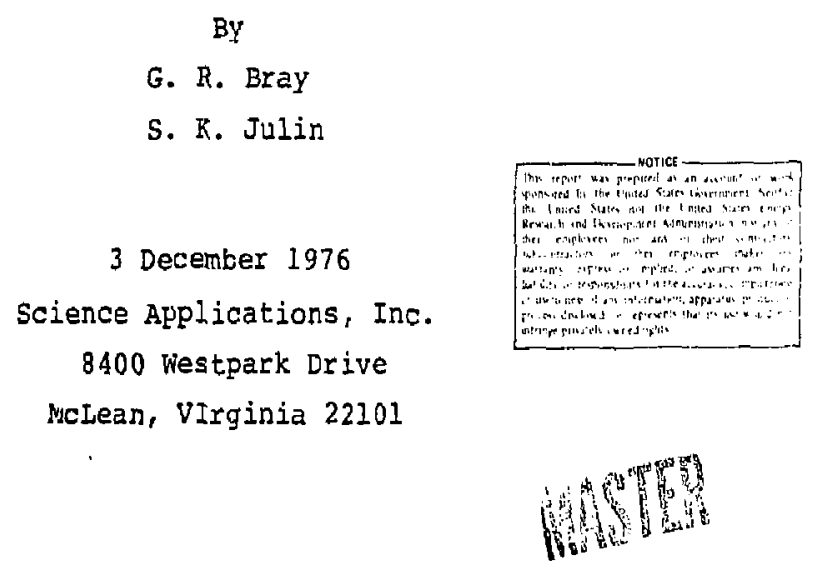
TABLE OF CONTENTS

Section

page

1.0 Introducticn........................... 1

1.1 Purpose of the Progran................ I

1.2 Conduct of the Effort................. 1

1.3 Classificatic objectives.............. 2

2.0 Radioactive Waste Forms and volumes, ........... 5

3.0 Review of Radicactive Waste Classification Systems. II

3.1 Introduction........................ 11

3.2 TAEA Categories................... 12

3.3 American Standards Institute-AIChE Radioactive Waste Categories....................... 14

3.4 Ferruccio Gera's 1968 and 1973 Waste Classification Systems.................., 21

3.5 American National Standards Institute Categories of Radioactive Waste (ANSI-N525)... 28

3.6 AEC Manual, Radioactive Waste Management Classifications...................... 31

3.7 J. 0 . Blomeke and C. W. Kee Definitions of Waste Types............................. 35

3.8 Summary of Established Content of Proposed Waste Classification Systems............. 38

4.0 Radioactive Waste Classification Systems Proposed by $\mathrm{TAP}$ Members........................... 40

4.1 Proposed Waste Classification System - I..... 40

4.2 Proposed Waste Classification System - 2.... 45 
TABLE OF CONTENTS (continued)

Section

4.3 Proposed Waste Classification system - 3.... 54

4.4 Proposed Waste classification system - 4.... 55

4.5 Proposed waste Classification System - 5... 57

5.0 Discussion......................... 59

5.1 Introduction..................... 59

5.2 System-I, Classification System Based on Waste Characteristics..................... 60

5.3 System-II Classification System Based on Characteristics of Disposal Means......... 65

6.0 Concerns and Opinions Expressed by Members of the Technical Advisory Panel.................. 78

7.0 Summary and Recommendations............... 81

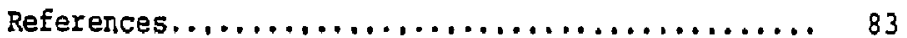

Appendix A - Technical Advisory Panel Members and Participants...................... A-1

Appendix B - Part 173.389 of Title 49, Code of Federal Regulations..................... B-1

Appendix C - Paper by Dr. W. A. Rodger............. C-1 
LIST OF FIGURES

Figures

Page

2.1 Fuel cycle wastes from Generation of 1000 MW-years of Electricity by LWRs Using Mixed U - Pu oxide Euels ....................... 7

2.2 Process operations and Wastes in the IWR Fuel Cycle..............................., 8

2.3 Post-Fission Wastes Expected from the LWR Fuel Cycle..,..,........................... 9

3.1 International Atomic Energy Agency Waste C.lassification system................. 15

3.2 American Standards Institute - AIChE Waste Classification system.................. 20

3.3 Gera's Classification System Based on Duration of Containment ....................... 22

3.4 Branca-Gera 1968 Waste Classification System.... 25

3.5 American National Standards Institute Waste Categories........................... 32

3.6 AEC waste Classification system.......... 36

4.1 Waste classification System $-1 \ldots \ldots \ldots \ldots \ldots \ldots 42$

4.2 Waste Classification System $-2 \ldots \ldots \ldots \ldots \ldots . \ldots 3$

4.3 Waste classification system $-3 \ldots \ldots \ldots \ldots \ldots \ldots 54$

4.4 Waste Classification System $-4 \ldots \ldots \ldots \ldots \ldots . \ldots 56$

4.5 Waste Classification System $-5 \ldots \ldots \ldots \ldots \ldots \ldots$..... 58

5.1 System I - Radioactive Waste Classification.... 64

5.2 System II - Radioactive Waste Classificaion.... 69

5.3 Considerations in Determining Disposal........ 70 


\section{LIST OF FIGURES (Continued)}

Figures

Page

Appendix C

1 Hazard Index of Reprocessing Wisites.......... C-16

2 Hazard Index of Spent Fuel Eletients........... $-i 7$

3 Comparison of Hazard Indices of Reprocessing Waste and Spent Fuel Elements,.............. $6-18$

4 Hazard Index of Leached Hulls................ C-19 
3.1 American Standards Institute - AIChE Radioactive Waste Categorization..........

3.2 Categories of Iiquid and Gaseous Wastes Proposed by Branca and Gera (1968).

3.3 Categories of Solid Wastes According to Activity Concentration and Half-Life Proposed by Branca and Gera $(1968) \ldots \ldots \ldots \ldots \ldots \ldots \ldots \ldots \ldots$

3.4 Categories of Solid Wastes According to Radiation Index Proposed by Branca and Gera (1968)..... 24

4.1 Waste Classification Categories........... 48

4.2 Waste Classification Subcategories......... 50

4.3 Waste Classification................. 51 Appendix C

I Hazard Index of Wastes from Reprocessing.... C-20

2 Hazard Index of Spent Fuel Elements Treated as

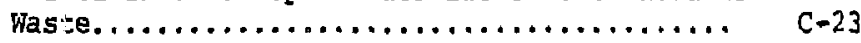

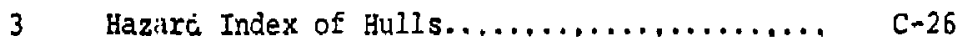

4 Maximum Concentrations Expected from On-Site Hulj. Burial,.......................... c-29 


\subsection{INTRODUCTION}

\subsection{Purpose of the Program}

The Nuclear Regulatory Commission has been charged with the responsibility of preparing regulations dealing with the handling, processing, packaging, storing, and disposal of waste containing radioactive materials. In order to provide a foundation for these regulations, a working radioactive waste classification system must be formulated. The purpose of such a system would be to define specific waste categories to allow for a commonly understood basis for managing nuclear waste between various nuclear facilities, particularly those producing and those disposing of the waste. The system should also be based on good management practices for nuclear waste considering public health, operational efficiency, and economics.

This document outlines most of the various zadioactive waste classification systems found in the iiterature and details several other classification systems proposed during the study effort. While possible waste management criteria and associated numerical values are suggested in this document, no attempt is made in this report to formalize or even recommend regulatory quantitative waste management criteria.

\subsection{Conduct of the Effort}

A Technical Advisory Panel (TAP) was established. This panel represented a broad spectrum of expertise and experience drawn from various governmental organizations, national laboratories, private consultants, and industrial interests. A tabulation of the panel members and invited guests can be found in Appendix $A$. 
A working document was prepared and distributed to TAP nembers. This document sumarized existing waste classification systems, outlined a new system, and provided a bibliography of feference material. The first meeting of the Technical Advisory Panel was helo on August 18 and 19, during which time the document was reviewed,

Based on the results of the first TAP meeting and comments from various TAP members, a second working document was prepared. This second document presented five new classification systems, all of which were formulated by TAP members. The second meeting of TAP was held on September 22 and 23. Specific recommendations and technical concerns were solicited in response to the proposed classification systems. The results of these meetings are presented by this final report.

\subsection{Classification Objectives}

All past and presently formulated radioactive waste classification systens may fall into one of three categories. These are based on: (a) the source of the waste, (b) physical characteristics of the waste, or (c) the nature of the isolation systems used to ultinately contain the various waste materials. Factors used as a basis for waste classification might include the following:

1. The toxicity and/or hazard of the waste

2. The total quantity of waste (in curies)

3. The longevity of waste as expressed in its half-life

4. Potential biological concentration mechanisins for various types of radioactivity

5. A consideration of whether the waste was naturally occurring or of manmade origin

6. Heat production 
7. Does the waste have potential value?

8. Its physical state (soljd, liquid, gas).

9. Is the entire material to be considered waste or is the waste a form of contamination of some other valuable material?

10. Type of radioactivity ( $a, B, Y$, neutrons, etc.).

In considering all of these factors the Technical Advisory Panel had certain objectives and ground rules for its operation. These included:

- An optimal waste classification would provide for categoric segregation of nuclear waste such that each category of waste can be managed to assure public protection without unaue economic penalty.

- The waste classification system should not be so operationally complicated as to discourage its effective application.

- A "perfect" classification system is unattainable. The "optimal" system must be largely based upon technical judgment. There will likely be objections to any system which is developed.

- Development of a waste classification system should be determined primari.iy by techrical considerations primarily involving protection of public health and safety. Economics should be a secondary factor. political and public opinion aspects thay be considered after technical issues are resolved.

- Nuclear waste will be assumed to have no economic value itself; therefore, future recovery will not be considered to be a viable possibility. 
- It is important that one reasonably acceptable waste classification system be developed and regulations accordingly promulgated at the earliest possible time. This would be helpful to industry in planning ano eliminating confusion. Almost any viable and generally accepted system could be considered superior to having no system at all. 


\subsection{RADIOACTIVE WASTE FORMS AND VOLUMES}

The radioactive waste types and voiumes generated by fuel cycle activities depend on the fuel cycle and the number of reactors being serviced. Assuming recycle of both uranium anc' plutonium, the generation of the following types of radioactive wastes can be expected:

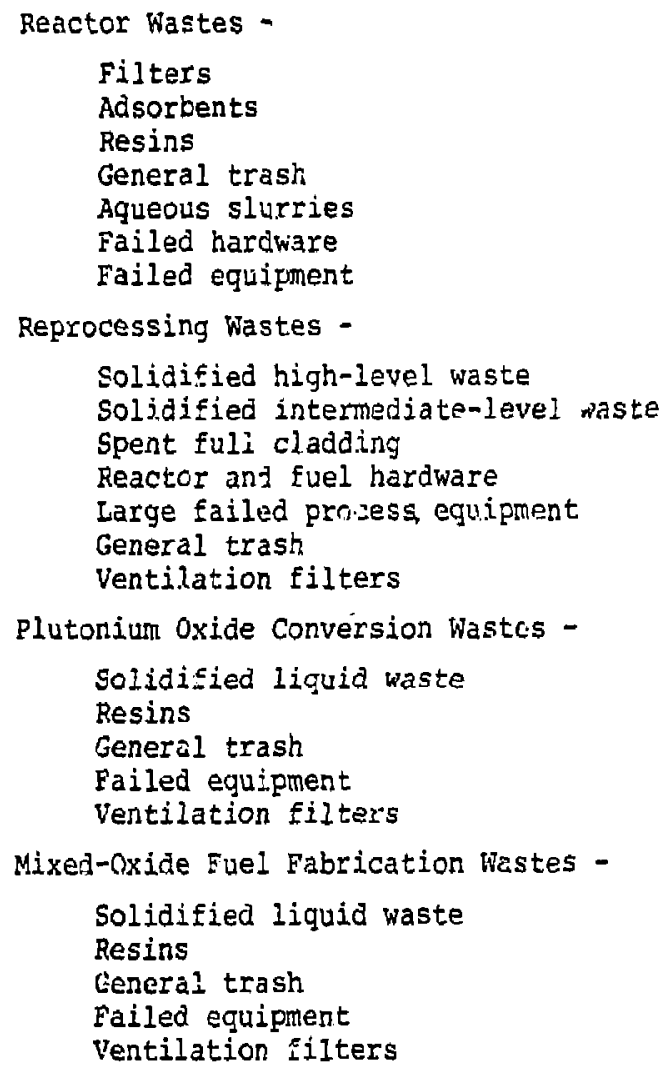

Decontamination and decomissioning wastes will also he generated from all of the above facilities. In addition future waste forms may include noble-gas fission products, fission product iodine and carbon-14. There are also various hospital and clinical radioactive wastes. 
Three projections of the volume of radioactive waste generated by the backend of the fuel cycle are shown in Figures 2.1, 2.2, and 2.3. The first projection, Figure 2.1, was prepared by J. 0. Blomeke and C. W. Kee for a paper. entitled "Projections of wastes to be Generated" dated July 1976. The second projection, Figure 2.2, i.s from ERDA-76-43, Volume I, Alternatives for Managing Wastes from Reactors and Post-Fission operations in the IWR Fuel cycle. The third set of projections is the most recent. These projections were prepared by Laverne Trevorrow of Argonne National iaboratury, october 12, 1976. 
Fuel cycle wagtes from generation of 1000 rW-years of electricity by LWhs using mxxed (U-Pu) oxide fuels

\begin{tabular}{|c|c|c|c|c|}
\hline & $\begin{array}{c}\text { Volume } \\
\left(\mathrm{m}^{3}\right)\end{array}$ & $\begin{array}{l}\text { Actifvitity } \\
\text { (MC1) }\end{array}$ & $\begin{array}{l}\text { Mess or } \\
\text { Actinfides } \\
(\text { tans })\end{array}$ & $\begin{array}{l}\text { Merwal } \\
\text { Power } \\
\text { (kW) }\end{array}$ \\
\hline High-level solidirted & 3.0 & 81.5 & 0.25 & 450 \\
\hline cladding hulls & 2.6 & 0.8 & 0.017 & 3.3 \\
\hline Noble gases & 1.0 & 0.24 & - & 0.36 \\
\hline Iodine & 0.049 & $1.25 \times 10^{-6}$ & - & $7.5 \times 10^{-7}$ \\
\hline LWR tritfum (rater) & 140 & $7.4 \times 10^{-6}$ & - & $2.3 \times 10^{-5}$ \\
\hline F.P. tritium (solidified) & 0.34 & 0.029 & - & 0.00062 \\
\hline Carbon-14 & - & $1.66 \times 10^{-5}$ & - & - \\
\hline Low-level TRU & 46 & 0.047 & 0.004 & 0.04 \\
\hline Intermediate-level TRU & 13.4 & 0.011 & 0.00012 & 0.054 \\
\hline Nontransuranium & 600 & 0.002 & - & 0.0065 \\
\hline
\end{tabular}

*Assumes approximately one-year aged waste. 


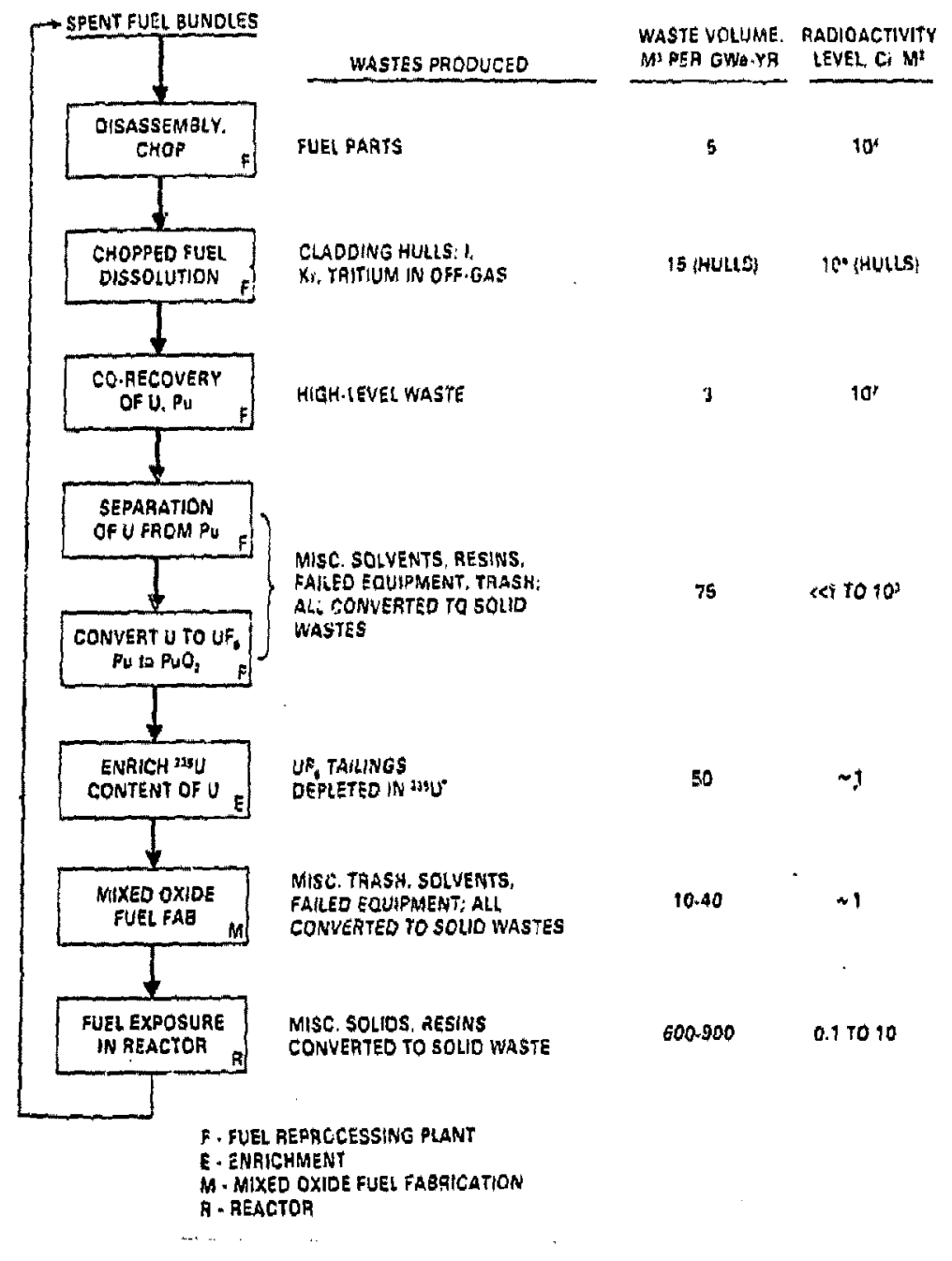

FIGURE 2.2 Process Oparations and Wastes in the LWR Fuel Cycle 
POST-PISSION WA STES EXPECTID FROM TMF IWR FUEL CYCLE (A21 Quentitios por awe-yr)

WASTP FORM $\left(\mathrm{m}^{3}, \text { vorume }^{\mathrm{excopt}} \text { as noted }\right)^{\mathrm{b}}$

Pactor Wastes

\begin{tabular}{|c|c|c|}
\hline $\begin{array}{l}\text { Slurries } \\
\text { Sludeses } \\
\text { Reging } \\
\text { RFPA fliters } \\
\text { Charcoal } \\
\text { Tragh } \\
\text { Patled requipment } \\
\text { Water Pilterg }\end{array}$ & $\begin{array}{l}2 \mathrm{F2} \\
3 \mathrm{EI} \\
6 \mathrm{FI} \\
5 \mathrm{EO} \\
2 \mathrm{FO} \\
2 \mathrm{FI} \\
6 \mathrm{FO} \\
4 \mathrm{FO}\end{array}$ & 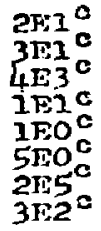 \\
\hline
\end{tabular}

Mixed Oxide Fuel Pabricetion Wnstes

\begin{tabular}{|c|c|c|}
\hline $\begin{array}{l}\text { Combustibie solids } \\
\text { Noncombustibio solida } \\
\text { Ligulds, alurvios } \\
\text { nEPA filterg }\end{array}$ & $\begin{array}{l}6 \mathrm{FI} \\
1 \mathrm{Fi} \\
2 \mathrm{EO} \\
4 \mathrm{FO}\end{array}$ & $\begin{array}{l}9 \mathrm{E2} \\
2 \mathrm{E2} \\
3 \mathrm{F2} \\
3 \mathrm{F2}\end{array}$ \\
\hline
\end{tabular}

a Volumesloxoept for high-level ruel reprocessing wastes) represent thoso of primary waste forms, before rolume-reducing troatments.

b 1 \& 1 to be read as $1 \times 10^{1}$; $I E-1$ to be road as $1 \times 10^{-1}$.

- Radionctivitios of rooctor westos assumed to be baged on surveys at shioping time, probably at about 6 months after removal from rosetor. 
POST-FISSION WASTES EXPJCTED FROM THF LWR FUEL CYCEE (CONT'D)

(a11 Quantitios per GWo-Jr)

Puel Reprocessing Weates.

\section{MASTE PORM}

\section{Fu1is}

niph-level sol1a

Lot-leveI I Inuid

Qages

Krypton

Xenon

Iodine

Garbonall

Trit 1 um

官

Combustible Tru
Combut

Combustible nonTru

Noncombustible TRU

Noncombuatible nonTRU

Slurries, sludFos, reging taU

siurries, siudres, resins nonTru

Pilters nonThu
VOTIMAE

(m oxcopt as notod)

152

$4 F O$

$3 \pi \alpha^{g}$

4 ro grams

2EO Grams

$5 \mathrm{FI}$

3 Fi

$5 \mathrm{FI}$

$1 \mathrm{miz}$

$5 \mathrm{E}-1$

$5 \mathrm{EO}$

7FO

d Based on 5-3r cooling after discharge.

- Based on 10-y cooling after diacharge.

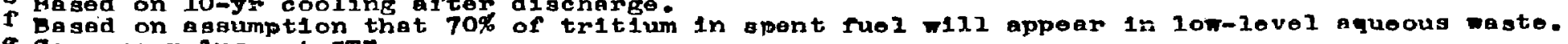

G Gegeoue rolume at aTP.

AADIOACTIVTTY TIFAMAI

(C1) POWER $3 \mathrm{Fi} 5^{\mathrm{d}} \quad 6 \mathrm{E7} 7^{\mathrm{a}} \quad 2 \mathrm{EO}$ IE7 ${ }^{\circ} \quad 1 \mathrm{E11} 1^{\circ}$ $24_{4}$ 3E5 $6 \mathrm{~m}-4$

2014 


\subsection{REVIEW OF RADIOACRIVE WASTE CLASSIFICATION SYSTEMS}

\subsection{Introduction}

During the past few years, there have been several radioactive waste classification systems proposed. These systems include:

1) Standardization of Radioactive Waste Categories, Published by the International Atomic Energy Agency, November 1967.

2) Proposed Definition of Radioactive Waste Categories, Published by the American Institute of chemical Engineers, 1967. (Since withdrawn)

3) "The Classification of Radioactive Wastes", Ferruccio Gera, Health Physics, Pergamon Press, 1974, Vol. 27.

4) "Categories of Radioactive Waste: ANSI-N525", American National Standards Institute. (Draft)

5) Part I, AEC Manual, Chapter 0511, "Radioactive Waste Management", Appendix 0511, U.S. Atomic Energy Commission, Approved 19 September 1973. (Now an ERDA Manual Chapter)

6) "Projections of Wastes to be Generated",. J. 0 . Blomeke and $\mathrm{C}$. $W$. Ree, International Symposium on the Management of Wastes from the LWR Fuel Cycle, July 11-16, 1976.

A review of these systems follows. 


\subsection{IAEA Categories}

The November 1967 IAEA technical report tabulated the information submitted by eleven countries concerning their systems of radioactive waste classification. The findings were that no two countries have the same classification system and even within some countries the systems were different.

The IAEA classifications first categorized the waste as liquid, solids or gaseous.

\section{Iiguid Wastes}

The sub-classification under liquid wastes was based on activity concentration levels as follows:

\begin{tabular}{cll} 
Category & Activity level $(A)$ & \multicolumn{1}{c}{ Remarks } \\
1 & $A \leq 10^{-6} \mu \mathrm{Ci} / \mathrm{ml}$ & not normally treated \\
2 & $10^{-6}<\mathrm{A} \leq 10^{-3} \mu \mathrm{Ci} / \mathrm{ml}$ & w/O shielding* \\
3 & $10^{-3}<\mathrm{A} \leq 10^{-1} \mu \mathrm{Ci} / \mathrm{ml}$ & shielding possible* \\
4 & $10^{-1}<\mathrm{A} \leq 10^{4} \mu \mathrm{Ci} / \mathrm{ml}$ & shielding necessary* \\
5 & $10^{4}<\mathrm{A} \mu \mathrm{Ci} / \mathrm{ml}$ & cooling necessary
\end{tabular}

*Treatment by usual methods i.e., evaporation, ionexchange or chemical treatment.

\section{Solid Wastes}

Three consicerations are present in the classification of solid waste per the IAEA system. These are:

1) For strong beta and gamma emitters the surface dose rate is controlling.

2) For strong alpha emitters the activity per volume $\left(\mathrm{Ci} / \mathrm{m}^{3}\right)$ controls. 
ij For large amounts of fissile materials, additional packing requirements control, such as IREA "Regulations for the Safe Transport of Radioactive Materials."

For the three considerations, the following classification is suggested:

\begin{tabular}{cll} 
Category & $\begin{array}{l}\text { Radiation dose }(D) \text { on } \\
\text { Surface of Wastes }(R / h r)\end{array}$ & \multicolumn{1}{c}{ Remarks } \\
\hline 1 & $0 \leq 0.2$ & \\
2 & $0.2<D \leq 2$ & \\
3 & $2<D$ & $\begin{array}{l}\beta \text { - } \gamma \text {-emitters, dominant; } \\
\alpha \text {-emitters are in- } \\
\text { significant. }\end{array}$ \\
& $\begin{array}{l}a \text { activity expressed } \\
\text { in Ci/m }\end{array}$ & $\begin{array}{l}\alpha \text {-emitters dominant; } \\
\beta-\gamma \text {-emitters in- } \\
\text { significant, criticality } \\
\text { is non-problem.* }\end{array}$
\end{tabular}

" "Criticality is a non-problem" means that: if criticality is a concern with the waste, then it is assumed that the solid wastes are treated and/or packaged to prevent criticality; also it is suggested that $\mathrm{Pu}$ and $U$ wastes are potentially retrievable and may be separated for economic reasons.

\section{Gaseous Wastes}

The basic consideration for classification of gaseous wastes is activity level as expressed in $\mathrm{ci} / \mathrm{m}^{3}$.

\begin{tabular}{|c|c|c|}
\hline Category & $\begin{array}{l}\text { Activity } 1 \text { level } \\
\text { (A) }(\mathrm{Ci} / \mathrm{m})\end{array}$ & Remariks \\
\hline 1 & $A \leq 10^{-10}$ & $\begin{array}{l}\text { Effluents not usually } \\
\text { treated }\end{array}$ \\
\hline 2 & $10^{-10}<A \leq 10^{-6}$ & $\begin{array}{l}\text { Effluents usually treated } \\
\text { by filtration }\end{array}$ \\
\hline 3 & $10^{-6}<A$ & $\begin{array}{l}\text { Effluents usually treated } \\
\text { by methods other than } \\
\text { filtration }\end{array}$ \\
\hline
\end{tabular}




\section{Discussion}

Figure 3.1 is a schematic of the IAEA waste classification system. The following waste characteristics must be known to use this system to categorize any given waste:

- Physical state (solid, liquid, gaseous)

- Activity level for $\alpha$-dominant solids, for liquics and gases

- Radiation dose at the surface for $\beta-\gamma$-dominant solids

- Radiation type, indiretly for solids.

In addition the following factors may be noted:

- The system is relatively uncomplicated.

- Difficult to assess for mixtures of nuclides of different types of radioactivity

- Expression of radioactivity in curies gives little indication of toxicity or hazard potential

- Categories give no direction as to disposal method

- Does not consider half-life or longevity of potential hazard.

\subsection{American Standards Institute - AIChE Radioactive Waste}

\section{Categories}

This waste classification system was formulated under the sponsorship of the American Institute of Chemical Engineer's and was approved in June $1967 .^{4}$

The premises on which this classification system is based are as follows:

(a) The major parameter for categorization is the "ratio of radionuclide concentration in the waste (at the time of consideration) to the MPC of the same waste constituents in water, air or 


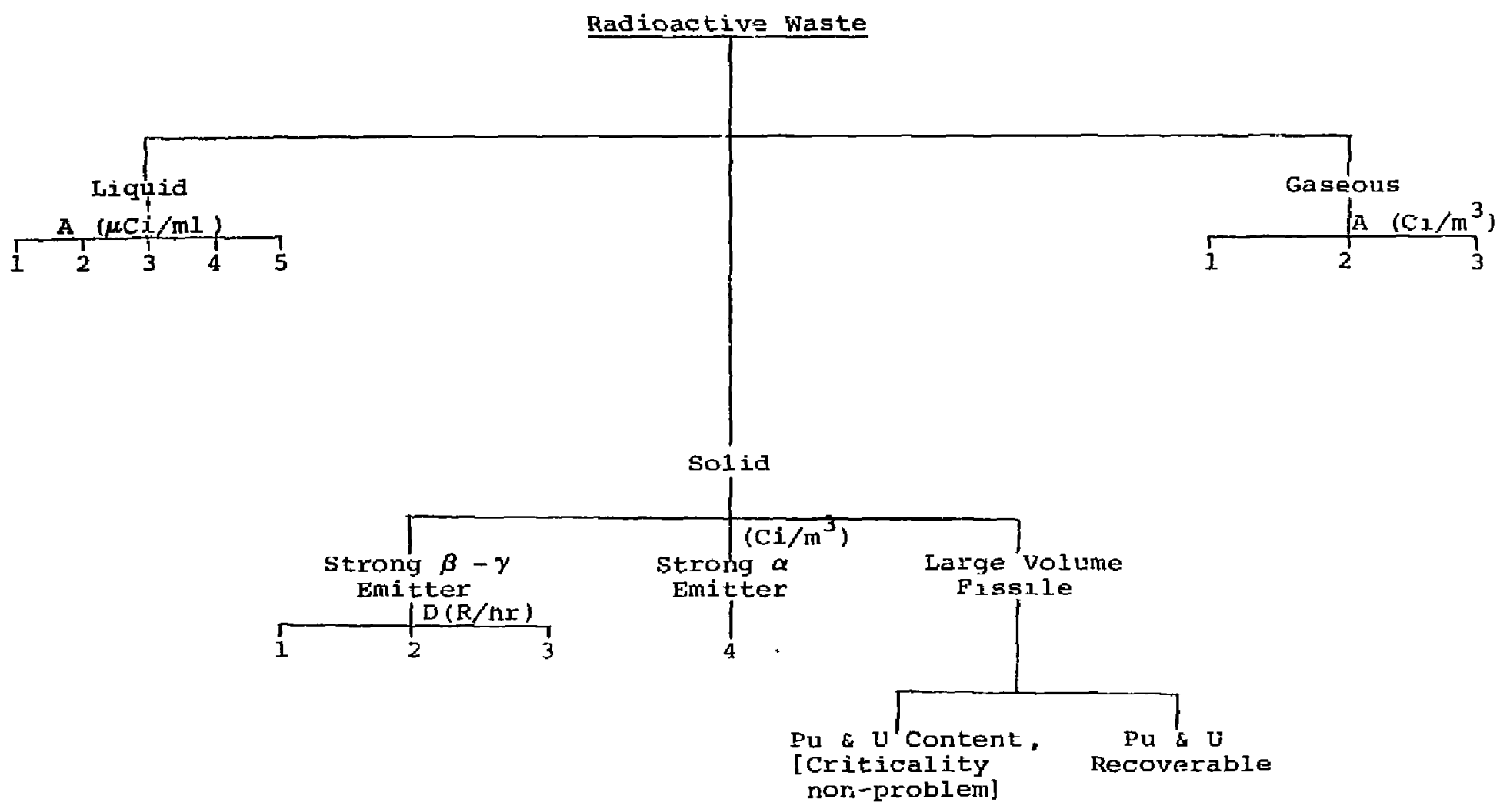

Figure 3.1 International Atomic Energy Agency Waste classification system 
solids" in terms of MPC, MPE (exposure) or MPQI (quarterly intake) as recommenced by the International Commission on Radiation Protection (ICRP) .

(b) Categorization should be done as wastes exist in containment or prior to release. Decay during storage may result in reclassification of wastes.

(c) Individual radionuclide concentrations must be determined for exact categories.

(d) Liquids and sases are treated as fluics; solids require further corsiderations.

(e) The smaller ICRP-MPC value should be used when MPC's are specified for different solubilities.

(f) Primary categorization parameters do not include: chemical content, physical properties, origin, total amounts of waste, $T_{t_{2}}$, degree of natural reconcentration once released.

(g) Definitions proposed are intended for use as descriptive information of the characteristics of wastes, in judgments involving treatment, disposal, regulatory action, definitions of safety.

The waste classification system is summarized by Table 3.1. The use of this table requires the following information:

(a) Where wastes contain mixtures of radionuclides, the radionuclide concentration to MPC (or etc.) ratio is determined by using the MPC for known mixtures or unidentified mixtures of radicnuclides as recommended by ICRP. 


\section{American Standards Institute - AIChE}

\section{Table 3.1 Radioactive Waste Categorization}

(Not Intended for Regulatory Use)

Class A (population leve!)

Liquid and gas

Solid

Surface radiation

Class B (occupational level) Liquid and gas

Solid

Surface radiation:

\section{Class C (low level)}

Liquid and gus

Solid

Surface radiation

Class C-1

Class $\mathrm{C}-2$

\section{Class D (intermedjate level)}

Liquid, gas, or solid

Solid

Surface radiation

Class D-1

Class D-2

\section{Class E (high level)}

Liquid, gas, or solid

Surface radiation:

Ciass E-1

Class E.-2
Emaximum permissible concentration (MPC) for members of the population at large lineluding persons living in the neighborhood of controlled areas)

smaximum permissible quarte:ly intake (MPQI) for members of the poputation at large including persons living in the neighborhood of controlled areas $/ \mathrm{kg}$. solid

\$maximum permissible whole booy , . sure (MPE)* for members of the population at large' lincluding persons living in the neighborhood of controlied areas)

$>$ Class A but s (MrC) occupational exposure (40-hr. wh) $>$ Class A but $\leqq$ (MPQI) $4 *$ for occupationa! exposure/kg. \$oljd

$>$ Class A but $\leq$ (MPE) ' for occupational exposure (40-hr. wk)

$>$ Class $\mathrm{B}$ but $\$ 10^{4} \times$ Class B

$>$ Class $B$ but $\leqq 10^{4} \times$ Class B

s(MPE) (occupational) at surface $>$ (MPE) (occupational) at surface'

$>$ Class $\mathrm{C}$ but $\leq 10^{4} \times$ Class C

$>$ Class $\mathrm{C}$ but $\$ 10^{4} \times$ Class C

(MPE) (occupational) at surface ${ }^{\dagger}$

$>$ (MPE) (occupational) at surface

\section{$>$ Class D \\ (MPE) 'loccupational) at surface $>$ (MPE) (occupational) at surface}

* ICRP Publication 6, Recorrmendations of the International Commission on Radiological Protection, as Amended 1959 and Revised 1962, " (1984). Pergamon Press (also rếerences 2 and 3 ).

'In the 1958 report of ICRP Committee If $(3, i)$ the recommended MPE :o the gonads or the whole body is 5 rem./gr. for occupational exposure. For the population at large, it is assumed to be $1 / 100$ of 5 , or 0.05 , for whole bady genetic silect.

Applies to surface of container, object, or pool of liquid.

\#+MPQI $=\left(\right.$ APC $_{w}$ for $168-\mathrm{hr}$. occupational exposurel $(2,200 \mathrm{ml} . / \mathrm{day})$ (91 days/quarter $=\left(M C_{n}\right)\left(2 \times 10^{5}\right) ;$ MIPC $C_{w}$ applies to water.

Section $C$ of "Radiation Protection-Recommendations of the International Commission on Eadiological Protectun" (adopted Sept. 9, 1958), Pergamon Press, London (1959) (ICKP. Pub, 1). 
(b) Units of MPQI/kg are used for solids because it is comparable to units for liquids and gases; even though solids are not considered ingestible.

As can be seen from Table 3.1, this classification system divides tha waste into five major categories, Classes $A, B, C, D$, and $E$, in ascending order of radionuclide concentrations. The following statements can be made about each as these categories:

Class A (Population Leve 1)

This category includes waste with radionuclide concentrations not exceeding (uncontrolled) population level MPC values. This shouid not be construed to mean that there are no restrictions on the release of these wastes to the environment other than constraints such as "ALAP" and ALARA."

Class B (Occupational Level)

One or more of the nuclides or the mixture of radionuclides exceeds Class A limits, but no radionuclide or mixture in liquid or gaseous wastes exceeds the specified MPC ( $40 \mathrm{hr} / \mathrm{wk}$ ) for normal occupational exposure and no nuclide or mixture in solid wastes exceeds specified MPQI/kg for normal occupational exposure.

\section{Class C (Low Leve1)}

Limits on radionuclide concentrations pertain to one or more reilonuclide or to a mixture of radionuclides. Treatment of some wastes in this category may convert the major fraction to a Class $A$ or $B$ waste, leaving a minor fraction of concentrated wastes.

Subclasses $\mathrm{C}-1$ and $\mathrm{C}-2$ are based on ICRP maximum permissible radiation exposure to the whole body. 
This, in many cases, would separate alpha from betagamma wastes.

(The category $C$ is based on radionuclide content; the sub-categories are based on surface radation.)

Class D (Intermediate Level) Generally, these wastes will be stored For safety and decay purposes, or converted to or incorporated in solids for ultimate disposal. (Incorporation intc organic matrix or cement before disposal is considered for Class $D$ wastes.)

Sub-categories are defined similarly to class C sub-categories.

Class E (High Level) Generally, these wastes will be stored for safety and decay purposes; or converted or incorporated into radiation-stable solids for disposal. Sub-categories similar to Class D sub-categories.

\section{Discussion}

Figure 3.2 is a schematic of the American Institute of Chemical Engineers waste clussification system. The following waste characteristics must be known to use this system to categorize any given waste:

- Physical state (solid, liquid, gaseous)

- Radionuclide content as MPC for liquids and gases or MPQI for solids

- Surface radiation as MPE for solids.

In addition the following factors should be noted:

- Categories are indicative of potentiz. hazards

- Relatively simple 


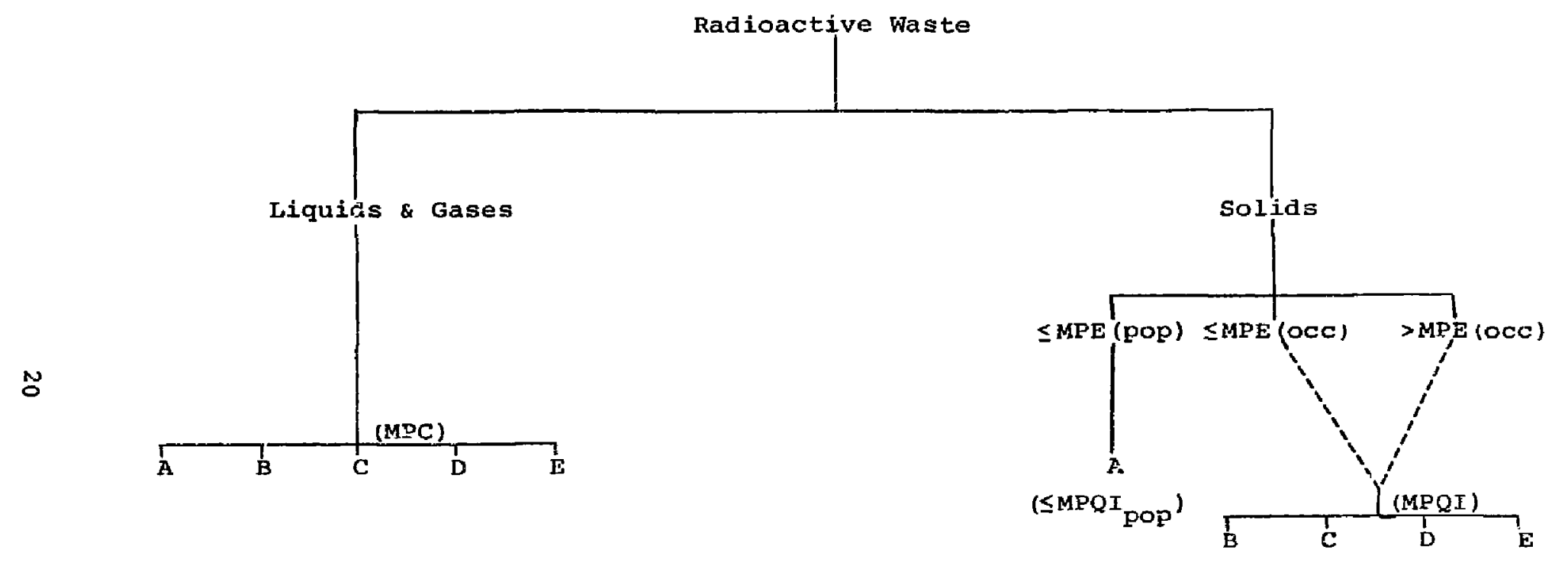

Figure 3.2 American Standards Institute - AIChE Waste classification System 
- Gives guidance as to suitable disposal method

- Considers physicel states

- May be operationally complicated

- Does not consider half-lifes as duration of hazard.

\subsection{Ferruccio Gera's 1968 and 1973 Waste Classification Systems}

Gera suggests that radioactive wastes should be classified on the basis of the duration of required containment. ${ }^{2}$ The clear segregation of wastes requiring containment for relatively short times from those presentiny a significant envircmental hazard for geologic time periods, would probably be sufficient. The point Gera makes is that the destiny of the waste is a relevant classification factor and that half-lives of the radionuclides contained in the waste are a contriiling element in future waste management steps. (Figure 3.3 is a schematic of this proposed system).

Tentative limits of concentration of long-lived alpha emitters to be used for the segregation of solid wastes have been proposed both in the United States and in France. These linits are $10 \mu \mathrm{Ci} / \mathrm{kg}$ and 10,000 tumes $\mathrm{MPC}_{\mathrm{w}}$, respectively. Concentration limits might not be sufficient criteria. It may be necessary to introduce an additional limit on the long-lived activity that can be disposed of in particular burial grounds. This inventory limit should be based on the jossible transfer to man after abandonment of the burial ground.

\section{8-Classification System}

Past work by Gera, published in 1968, developed a rigorous waste classification system based on MPC's, activity concentrations, half-lives and exposure rates. This system is presented in Tables $3.2,3.3$ ana 3.4 (schematically in Eigure 3.41 . A detailed knowledge of the nature of the 


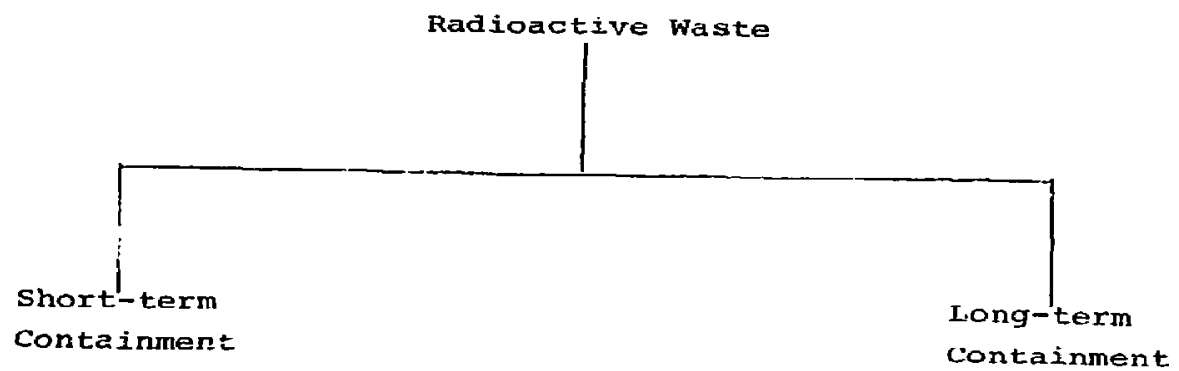

Figure 3.3 Gera's Classification System Based on Duration of Containment 
THE CLASSIFICATICN OF RADIOACTIVE WASTES

Table 3.2 Categories of Liquid and Gaseous Wastes

Proposed by Branca and Gera (1968)

\section{Categories according to MPC multiplication factors}

A: $\angle M P C$

B: from MPC to $10^{3}$ MPC

C: from $10^{3} \mathrm{MPC}$ to $10^{6} \mathrm{MPC}$

D: from $10^{6}$ MPC to $10^{\circ} \mathrm{MPC}$

$E:>10^{9}$ MPC
Examples of possible

waste categories

A-1 (Discharge)

A-2 (Treatment; D.F. $<10^{3}$ )

B-1 (Discharge)

B-2(Treatment; D.F. $\left.<10^{3}\right)$

B-3 (Treatment; $10^{3}<0$. F. $<10^{6}$ )

C-1 (Discharge)

C-2 (Treatment; D. . $_{0}<10^{3}$ )

C-3 (Treatment; $10^{3}<0 . F_{6}<10^{6}$ )

C-J (Treatment; D.r. $>10_{3}^{6}$ )

D-2 (Treatment; D.F. $<10^{3}$ )

D-3 (Treatment; $10^{3}<$ D.F $<10^{6}$ )

D-4 (Treatment; D.F.>10)

D-5 (Containnent)

E-3 (Treatment; $10^{3}<$ D. F $<30^{6}$ )

E-4 (Treatment; D.F.>10)

E-5 (Containment)
Categories according to treatment

1: No treatment. Discharge

2: Treatment with D.F. up to $10^{3}$

3: Treatment with D.F. between $10^{3}$ and $10^{6}$

4: Treatment with D.F. exceeding $10^{6}$

5: No treatment. Containment

D.F. = Decontanination factor. 
Table 3.3 Categories of Solid Wastes According to Activity Concentration and Half-Life Proposed by Branca and Gera (1968)

\begin{tabular}{|c|c|c|c|}
\hline Category & $\begin{array}{c}1 \\
T_{1}<250 \text { days } \\
T_{1}>10^{11} Y Y\end{array}$ & $\begin{array}{l}2 \\
250 \text { days }<T_{\frac{1}{2}}<10 y x \\
10^{8} y x<T_{13}<10^{-1} y x\end{array}$ & $\begin{array}{c}3 \\
10 y r<\mathrm{T}_{\frac{1}{3}}<10^{8} \mathrm{yr}\end{array}$ \\
\hline A & $<10^{-4}$ & $<10^{-5}$ & $<10^{-6}$ \\
\hline B & $10^{-4}-10^{-1}$ & $10^{-5}-10^{-2}$ & $10^{-6}-10^{-3}$ \\
\hline C & $10^{-1}-10^{2}$ & $10^{-2}-10$ & $10^{-3}-1$ \\
\hline D & $10^{2}-10^{5}$ & $10-10^{4}$ & $1-10^{3}$ \\
\hline$E$ & $>10^{5}$ & $>10^{4}$ & $>10^{3}$ \\
\hline
\end{tabular}

Activity concentration in $\mu \mathrm{Ci} / \mathrm{cm}^{3}$ or $\mu \mathrm{Cl} / \mathrm{g}$.

Table 3.4 Categories of Solid wastes According to Radiation Index Proposed by Branca and Gera (1968)

\begin{tabular}{cc} 
Category & $\begin{array}{c}\text { Radiation Index } \\
i=k^{*} D \ddagger\end{array}$ \\
\hline II & $<0.002$ \\
III & $0.002-0.02$ \\
IV & $0.02-0.2$ \\
V & $0.2-2$ \\
\hline
\end{tabular}

* Surface of waste item or package, perpendicular to the direction of measurement

$\begin{array}{cr}<1 \mathrm{~m}_{2}^{2} & 1 \\ 1-5 \mathrm{~m}^{2} & 3 \\ 5-20 \mathrm{~m}_{2}^{2} & 6 \\ >20 \mathrm{~m}^{2} & 19\end{array}$

Coefficient $k$ reflects the oifferent attenuation of exposure rate with the distance as a function of source dimensions; the values are taken from "Regulations for the Safe Transport of Radicactive Materials", p. E9 (IAEA, 1967).

FD is exposure rate in air in $\mathrm{R} / \mathrm{hr}$, measured at a distance of 1 al from the waste. 


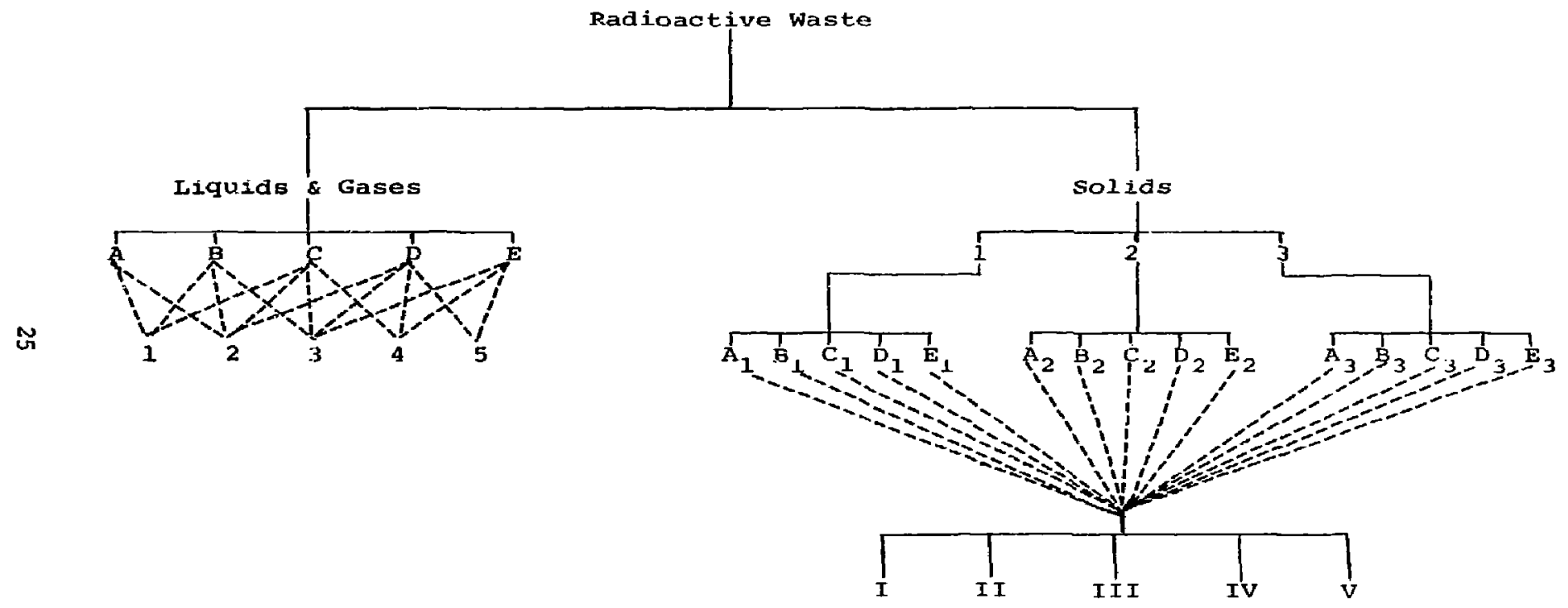

Figure 3.4 Branca-Gera 1968 Waste classification System 
radionuclides and their respective concentrations was required for use of this system. Subsequent work on the development of a functional waste classification systems led Gera to conclude that his 1968 proposed system and those comparable to it were, in his words, "rather impractical and not relevant to the actual needs of waste management."

Gera ventures that a succinct definition of the terminology in use today may be a sufficient classification system. His proposed definitions follow.

\section{3-Classification System}

\section{High-Level Waste:}

only the wastes provided by reprocessing of spent fuels or the spent fuels themselves. These wastes contain the bulk of the fission products and significant amounts of the long-lived $\alpha$-emitters. Liquid concentrations are in the thousands of curies per liter. Wastes are self-heating. Long-lived $\alpha$ emitters exist in concentrations too high to allow disposal for periods far exceeding the expected life of engineered storage structures.

\section{Low-Level Naste:}

Low hazard potential with activity concentrations not much higher than MPC's. Large volumes that require no shielding and most may be treated with simple filtration or flocculation techniques. Solid wastes that can be handled without particular precautions, often suspect of any contamination.

\section{Alpha-Bearing Waste:}

All wastes containing $\alpha$-emitters in excess of some appropriate threshold value defined as alpha-bearing wastes; in particular, long-lived isotopes of transuranium elements. 
Cladding Waste:

Cladding hulls and associated fuel assembly ha:dware from mechanical decladding of spent fuel. Most of the activation products and portions of the sorbed fission products and alpha-emitters are present.

Intermediate-Ievel Waste:

All wastes not included in the preceeding categories. These wastes cannot be released to the environment, usually reguire treatment and shielding but not cooling.

\section{Discussion}

The 1968 classification system requires the following waste characteristics be well known:

- Physical state

- MPC

- Half-life

- Activity concentration

- Exposure rate

In addition the following considerations should be noted:

- The system is based upon potential hazard potential

- It considers physical states

- Frovides guidance on disposition of waste

- Tends to be complex in that it requires detailed knowledge of waste composition.

These imply a detailed knowledge of the radionuclide content also is available for each waste.

The 1973 classification system requires knowledge of the following waste characteristics:

- Source of the waste

- Dominant radiation

- General operational information 
In addition the following considerations should be noted:

- The system is simple and practical

- Provides guidance as to disposition of waste.

\subsection{American National Standards Institute Categories} of Radioactive Waste (ANSI-N525)

In the interest of better comnunications regarding radioactive wastes between the nuclear energy industry and the public, the Institute set forth definite meanings to terms used to describe broad categories of wastes. ${ }^{3}$ The classification systems major pareneters were the source of the waste in the fuel cycle and the physical nature of the radionuclides contained in the wastes. Tne waste categories specifically exclude: (a) materials being stored for possible future recovery of radioactive contents of value and (b) materiais normaliy of use which are being stored for possibie future removal of the radioactive contaminant(s). For liquid and gaseous wastes, the concepts used for specific concentrations are those of the Federal Radiation Council in the "Radioactivity Cencentration Guide" (RCG! .

The redioactive waste categories defined below include solid waste sub-categories defined by parameters independent of possible mechanisms of exposure.

High-Level Solid or Liquid Waste: (material meeting either of the following)

(a) Aqueous waste stream from first cycle of solvent extraction, including waste streams from subsequent cycles separate or added to the first; solids or concentrates prepared from this first cycle and adidions to it, where extraction cycles are intended for reprocessing (not including research reactors ( $1 \mathrm{MW})$. 
(b) Streams from partial separations where specific activity remains high.

(c) Fuel elements from reactors (not research reactors $<1$ (M) .

Low-Level Liquid Waste:

Wastes that after treatment (no more complex than filtration or ion exchangel can be released with reasonable assurance that the concentration in the water at the point of release will be less than the RCG value for the public (weighting individual RCG values by relative abundance of radionuclides present.)

Intermediate-Level Liquid Waste:

Liquid wastes not included in High-Level and Low-Level Liquid Waste categories. Wastes will eventually be treated to yield a processed fraction of low-level liquid wastes and a fraztion which will be added to. high-level liquid waste:s.

Low-Level Gaseous Wastre:

Gaseous materials (including entrainec or suspended volatile material, vapors, droplets and particulate matter) which after treatment (no more complex than conventional filtration or scrubbing) can be released as specified in the Low-Level Iiquid Waste category.

Stored Gaseous Waste: (high-level gaseous waste) Gaseous or volatile material not defined in the LowLevel Gaseous Waste category, which are stored either in gaseous form or adsorbed in or on a solid media. 
SOLID WASTE

-1- Mine and Mill Tailings

Tailings from mining or milling of uranium or thorium ores, in which daughter products are dispersed throughout the tailings so their concentration is no higher in any significant portion of a tailings pile, than it was in original ores.

-2- Natural Uranium and Thorium Materials

Solid waste with no radiation content exceeding the usual criteria for occupational radiation safety, except for natural uraniun, enriched uranium or thorium which are the limiting potential hazard in the handling of the wastes.

-3- Nuclear Reactor Waste

Material nomally non-radioactive containing no activity except that induced by neutron or other subatomic particle capture.

4- Solid Waste Category 4

Material containing or contaminated with fission products or other radioactive materials not defined elsewhere, such that the concentration of selected actinides is less than the minimum concentration as stated in solid waste category 5 .

\section{-5- Selected Actinide Waste}

Material containing or contaninated with U-233, $\mathrm{U}-232$, all transuranium radionuclides and $\mathrm{Ra}-226$ at concentrations of $\geq 10 \mathrm{nCi} / \mathrm{g}(10 \mu \mathrm{Ci} / \mathrm{kg})$. (Ra-226 is included with the actinides because of its comparable properties). 
-6- Solid Waste Category 6

Solid material included in High-Level Solid or Liquid

Waste category with the notation that relatively

small amounts of such materials will not effect the

status of solid waste category 4 or solid waste

category 5. (e.g., surface contamination on equip-

ment which has been in contact with high-level wastes

or samples removed for analytical control purposes.)

\section{Discussion}

Figure 3.5 is a schematic of the ANSI racioactive waste categories. The following waste characteristics must be known to use this system to categorize any given waste:

- Physical state

- Source of the waste

- Activity concentrations (1iquids and gases)

- Transuranic and Ra-226 concentration.

In addition the following factors should be considered:

- The system specirically excludes materials stored for future extraction of valuable material

- Does not discriminate between man-made and naturally occurring radioactivity. It only addresses potential hazards

- The system does not provide guidance for disposition of waste

\subsection{AEC Manual, Radioactive Waste Management Classifications}

The classifications specified by the AEC are for use as definitions of wastes and terminology for AEC-assigned responsibilities, authorities and procedures for radioactive waste management. ${ }^{5}$ The definitions do not represent 


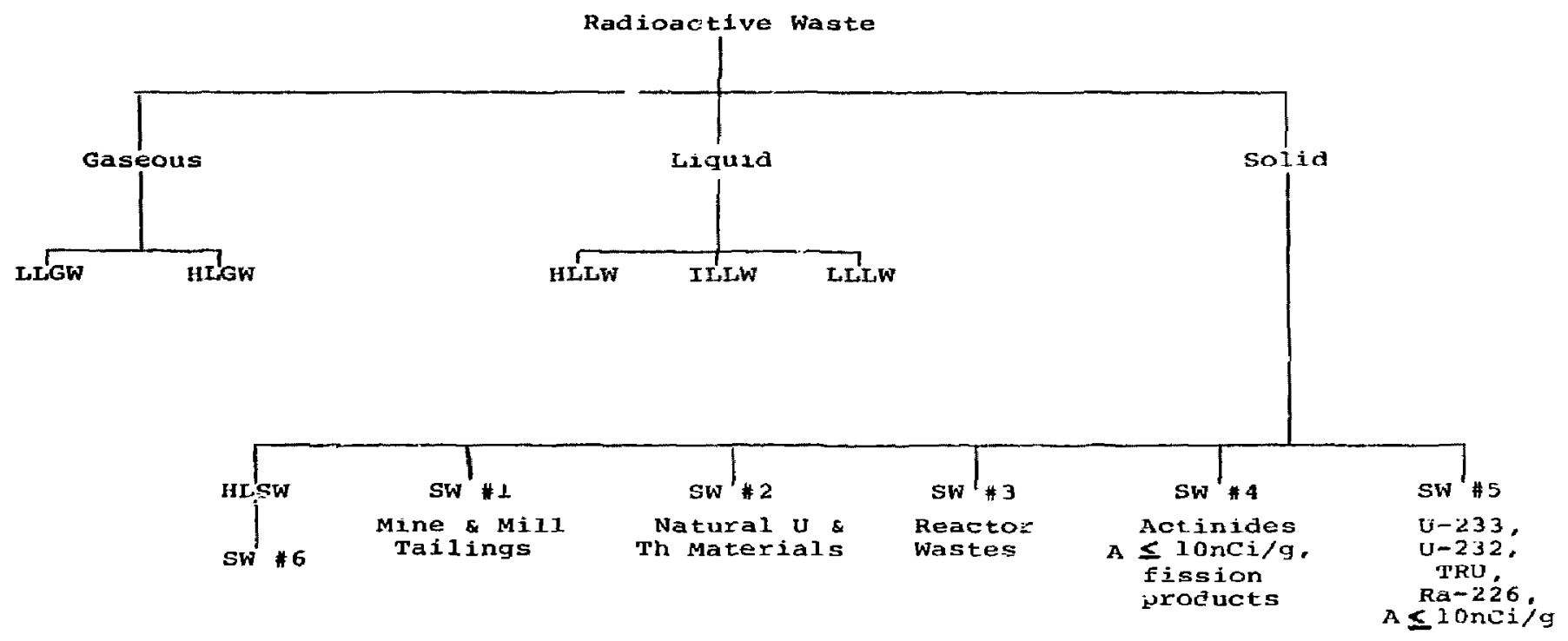

Figure 3.5 Anericar. National Standards Institute waste Categories 
a rigorous, comprehensive classification systen, but the: do provide existing ground work done by ERDA's predecessor.

Radioactive wastes in general and liguid and solid wastes definitiors are as follows:

Radioactive Waste - Materials of no value consistiny of, including, or contaminated with radioactive material in excess of the levels or concentrations permitted in AEC Property Management Instructions for unconditional release of exces's property. This includes (a) stored liquid, solid, or gasecus residues from chemical or metallurgical processing of radioactive materials; (b) discarded items such as defective equipment and building rubble, not radioactive in themselves but contaminated with radioactive materials; and (c) discarded items containing induced radioactivity. Treated as a soparate category are: (1) irradiated fuels stored for possible processing: (2) radioactive scrap stored for possible recovery o: useful values; and (3) materials and equipment stored for possible future. use following decontamination.

Liquid Radioactive Waste - Solutions, suspensiors, and mobile sludges, cortaminated with radioactive materials.

Solid Radioactive Waste - Material that is essentially dry but may contain sorbed radioactive fluids in sufficiently smal! amounts to be immobile when buried in dry soil.

Classifications, based on these definitions are specified for common terminology as follows: 
High-Heat Liquid Waste - Liquid waste containing sufficient thermal energy to require some supplemental means of cooling, such as cooling coils.

High-Level iliquid Waste - The aqueous waste resulting from the operation of the first-cycle extraction system, or equivalent concentrated wastes from subsequent extraction cycles, or equivalent wastes from a process not using solvent extraction, in a facility for processing irradiated reactor fuels.

High-Level Waste - (a) high-level liquid waste, or (b) the products from solidification of high-level liquid waste, or (c) irradiated fuel elements if discarded without processing.

Other Liquid Waste - Iiquid waste, not within the definitions of high-level liquid waste.

Transuranium-Contaminated Solid Waste - Those contaminated with certain alpha-emitting radionuclides of long half-life and high specific radiotoxicity to greater than 10 nanocuries/gram (10 microcuries/ kilogram), subject to the following conditions and understandings:

a. The radionuclides included are U-233 (with its daughter products), plutonium, and transplutonium nuclides except Pu-238 and Pu-24l. (Note that Pu-238 and $\mathrm{Pu}-241$ waste should be handled as transuranium-contaminated waste when so indicated by $\mathrm{Pu}-239$ impurities or when required by local burial criteria.)

b. The activity density may be averaged over the contents of individual shipping containers, such as 55-gallon drums, including materials added for shielding or sorption of liquids. 


\section{Discussion}

Figure 3.6 is a schematic of the AEC categorization system. The following waste characteristics must be known:

- Physical state (solid, liquid)

- Thermal energy

- Source of waste

- Transuranic activity concentration

In addition the following factors should be considered:

- Considers physical state

- The specific activity does not indicate the potential of hazard

- Iossibly over restrictive.

\subsection{J. 0. Blomeke and C. W. Kee Definitions of Waste Types}

The above authors presented a paper entitled "Projections of Wastes to Be Generatec" at the International Symposium on the Management of Wastes from the LWR Fuel Cycle, July 11-16, 1976 . The purpose of the paper was to provide a series of projections as to the type and quantities of wastes that will be generated by the nuclear fuel cycle until approximately the year 2000 .

The paper identified and discussed the following types of radioactive wastes:

High-Level wastes

Cladding wastes

Noble-gas fission products

Fission-product iodine

Tritium wastes

Carbon-14

Low-level transuranium wastes

Intermediate-level transuranic wastes

Nontransuranium wastes

Ore tailings 


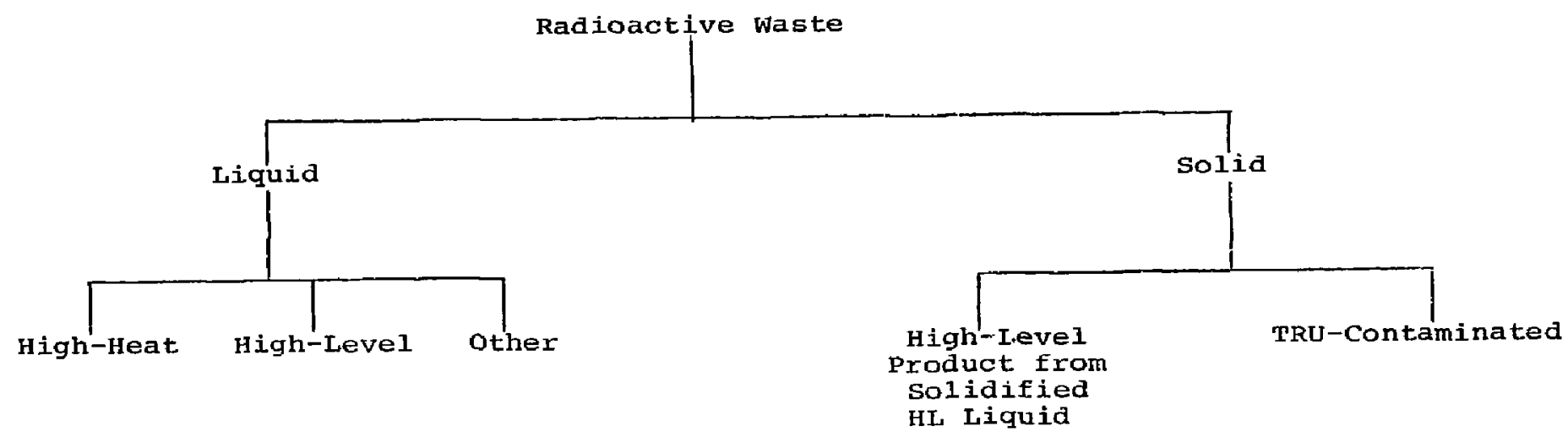

Figure 3.6 AEC Waste Classification System 
The paper defined each of these individual waste types as follows:

High-level wastes are composites of the liquid waste streams arising from the reprocessing of spent fuels. These wastes contain more than $99.9 \%$ of the uonvolatile fission products, 0.58 of the uranium and plutonium, and all the other actinides formed by the transmutation of the uranium and plutonium in the reactors.

Cladding wastes consist of solid fragments of zircaloy and stainless stell cladding and other structural components of fuel assemblies that lemain after the fuel cores have been dissolved.

Noble-gas fission products, krypton separated from reprocessing plant off-gas ard packaged, together with other noble-gases collected.

Fission-product iodine, whose radioactivity at the time of packaging and shipment is due sọlely to $1.2 \times 10^{7}$ year Iodine-129, is recovered with a yield of 99.98 at the reprocessing plant.

Tritium wastes are generated at nuclear power stations and at reprocessing plants.

Carbon-14 is produced in oxide-fueled reactors principally by an $(n, p)$ reaction with nitrogen-14 impurity in the fuels, but also as the product of an $(n, \alpha)$ reaction with oxygen-17.

Low-Level transuranium wastes are defined as those solid or solidified materials that contain plutonium or other longlived alpha enitters in known or suspected concentrations greater than $10 \mathrm{nci} / \mathrm{g}$, and yet have sufficiently low external radiation levels after packaging that they can be handled directly. 
Intermediate-level transuranium waste is defined as those solid or solidified materials that contain long-lived alpha emitters at concentrations greater than $10 \mathrm{nCi} / \mathrm{g}$, and have typical surface dose rates between 10 to 1000 millirems per hour after packaging due to fission-product contamination.

Nontransuranium waste is composed of those diverse materjals that are contaminated with low levels of beta- and gammaemitting isotopes, but contain less than $10 \mathrm{nCi}$ of long-lived alpha activity per gram.

Ore tailings are the results of the mining and milling operations for the recovered of yellow cake, $\mathrm{U}_{3} 08$.

\section{Discussion}

The following properties of radioactive wastes must be specified when using Blomeke and Kee's classification system:

- Source of the waste

- $\mathrm{Kr}-85, \mathrm{I}-129, \mathrm{E}-3$ or $\mathrm{C}-14$

- Activity concentration for long-lived $\alpha$-emitters

In adition the following factors should be considered:

- The system is clear-cut in its definitions of categories

- No guidance is provided for the disposition of waste

- Little indication of relative hazard.

\subsection{Summary of Established Content of Proposed Waste Classification Systems}

Waste classification systems or methods discussed previously present a consensis, among those in the field, on some of the important considerations necessary to satisfy the intent of a classification system. These considerations appear to be: 
- Degree of potential hazard

- Measure of potential health hazards such as MPC's

- Physical state; solid, liquid or gaseous.

of equal emphasis and importance, but less often included in classification systems are the following considerations:

- Hazard duration; half-iife

- Disposal options, containers, conditions and permanence

- Specific nuclide content

- Specific emissions; alpha or beta-gamma emissions

- Point of waste generation in the fuel cycle; (i.e., waste stream of first cycle of reprocessing, hulls, etc.)

In many cases, the characteristics of radioactive waste included in the definitions of waste classes are overlapping or redundant. In sumary, a determination of the most significant yet independent characteristics of wastes can be made and a classification system developed around that determination. 


\subsection{RADIOACTIVE WASTE CLASSIFICATION SYSTEMS PROPOSED BY TAP MEMBERS}

The classification systems presented in this chapter are those proposed for discussions in the Technical Advisory Panel's working sessions by the panel members. A few of these systems were developed in some detail, others represent the basic structure a classification system might have, with only brief analysis of the details which may be necessary in applying such systems to waste management questions.

\subsection{Proposed Waste Classification System - 1}

The primary consideration iis the developrent of classification System - 1 is the method of disposition of the waste material. The basic criteria applied is that the method of disposition will provide reasonable protection to man and his environment.

The disposition methods are divided into four major categories as follows:

1) Release of Effluenets. Defined as the release of those radioactive wastes whose concentrations are or can be made to comply with guidelines given in $10 \mathrm{CFR} 20$ for discharge directly to the environment

2) Interim Sturage. Defined as storage for an unspecified length of time of radioactive wastes to await, radioactive decay; special 'reatment such as solidification, incineration, chemical change, hiat dispersal, etc.; shipment, or any other operation that mi: require retention of the waste for some period of time. 
3) Active confinement. Def: ned as those carefully selected sites where nuclear waste can be disposed withont significant insult to man and his environment. Shallow land burial would fall into this category.

4) Isolation. Defined as those methods tinat isolate the waste from man and his environment for long periods of time. Deep burial in geological formations, deep sea burial, extraterrestrial disposal methods would fall in this category.

All radioactive isotopes could be classified into two groups based on their potential hazard. isimilar to the seven groups established for radioactive shipments as given in 49 CFR 173.3891.* It is suggested that all radioisotopes that fall into transport groups I and II be classified as Waste Group I. All other nuclides are classified to Waste Group II with the exception of ${ }^{106}$ Ru which should go into Waste Group $\bar{I}$. This would put all the heavy ulement alpha emitters (including the TRUs) plus those hazardous beta emitters such as ${ }^{90} \mathrm{Sr}$ and ${ }^{106} \mathrm{Ru}$ in Group I. (Figure 4.1 is a schematic of this waste classification system).

In addition, it is proposed that concentration and total inventory limits be established for each individual site selected for active confinement. The limits for waste aroup I material would be more restrictive than for waste Group II material. The limits would be further defined as one linit for the immediate time and one limit for 100 years after use of the site. It is suggested that 100 years be picked becaise this seems a reasonable length of time that control of the site can be maintained and it also is about the time that

*Included as Appendix B in this report, is Part 173.389 of the Code of Federal Regulations, Title 49. This classification system is used for radioactive waste transportation purposes and has been quite functional. 
Figure 4.1. Waste Classification system - I

\section{Radioactive waste}

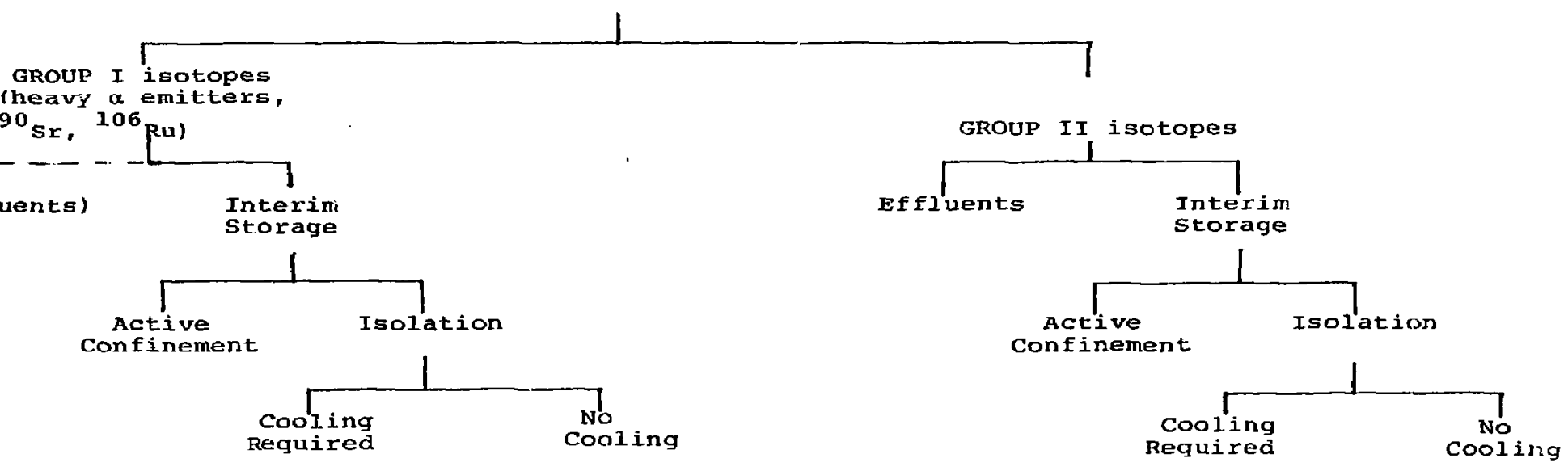


fission product nuclides significantly reduce due to decay and the TRU nuclides assume greater relative importance.

The total inventory limits would be established after careful study of the site. Such factors as rainfall, sutterranian water flow, ion exchange in the soil, etc. would be used to establish both the immediate and the 100 year limits.

On the other hand however, it would be expected that the concentration limits be the same values for all sites in the country. These limits should be established after careful study of the potential hazard, should an unknowing entry into the buried material take place. Some preliminary numbers to illustrate the point are as follows:

Concentration limits for Waste Group I material could be

$$
\begin{aligned}
& \text { for imnediate burial }-1.5 \mathrm{ci} / \mathrm{m}^{3} \\
& \text { for } 100 \text { year buxial }-0.15 \mathrm{Ci} / \mathrm{m}^{3}
\end{aligned}
$$

Concentration limits for Waste Group II material could be

$$
\begin{aligned}
& \text { for immeidate burial }-15.0 \mathrm{ci} / \mathrm{m}^{3} \\
& \text { for } 100 \text { year burial }-1.5 \mathrm{ci} / \mathrm{m}^{3}
\end{aligned}
$$

For example, assume a plant has a 55 gallon drum (volume = $0.20 \mathrm{Bm}^{3}$ ) of waste containing $608 \mathrm{sr}-90$ and $408 \mathrm{Ru}-106$, by activity. The immediate burial limit of $1.5 \mathrm{ci} / \mathrm{m}^{3}$ implies the drum may contain at burial:

$$
\begin{aligned}
& \mathrm{Sr}-90+\mathrm{Ru}-106=\left(1.5 \mathrm{Ci} / \mathrm{m}^{3}\right)\left(.208 \mathrm{~m}^{3}\right)=0.312 \mathrm{Ci} \\
& \text { with }(.6)(.312 \mathrm{Ci})=0.19 \mathrm{Ci} \text { of } \mathrm{Sr}-90 \\
& \text { and }(.4)(.312 \mathrm{Ci})=0.12 \mathrm{Ci} \text { of Ru-106 }
\end{aligned}
$$

W. A. Rodger: Critical Evaluation of the Limits of Transuranic Contamination of Low Level Waste, August 1975. Nuclear S3fety Associates, Bethesda, Maryland. 
The 100 -year limit of $0.25 \mathrm{ci} / \mathrm{m}^{3}$ implies the arum may contain at burial:

$$
\operatorname{Sr}-90\left(\mathrm{e}^{-\lambda_{1} t}\right)+\operatorname{Ru}-106\left(\mathrm{e}^{-\lambda_{2} t}\right)=\left(.15 \mathrm{Ci} / \mathrm{m}^{3}\right)\left(.208 \mathrm{~m}^{3}\right)=0.0312 \mathrm{Ci}
$$

Since at burial there is $2 / 3$ as muci Ru-106 as $5 r-90$, then at burial:

$$
\begin{aligned}
& \text { sr-90 }=\frac{.0322 \mathrm{Ci}}{\left(e^{-\lambda_{1} t}\right)+2 / 3\left(e^{-\lambda_{2} t}\right)}=0.34 \mathrm{Ci} \\
& \text { and } R u-206=2 / 3(.35)=0.23 \mathrm{Ci} .^{\star}
\end{aligned}
$$

Since the immediate burial limits are more restrictive in this case, the amount of $\$ r \% 90$ and Ru-106 allowed per drum would be $0.19 \mathrm{Ci}$ and $0.12 \mathrm{Ci}$ respectively.

For a mixture of plutonium isotopes, the governing criterion will be the 100 year burial limits because of the long-half lives of the plutoniun isotopes. This is obviously the rase for Pu-239 with a 25,000 year half 1 ife. For shorter lived $\mathrm{P}\left(1-238\left(\mathrm{~T}_{1 / 2}=89 \mathrm{y}\right)\right.$ the following example leads to the same conclusion.

Assume a plant has the same 55 gallon drum containing waste with a composition of 808 Sr-90 anv $2085.2-238$, by activity. The immediate burial limit of $1.5 \mathrm{Ci} / \pi^{3}$ implies an activity ilmit of $0.25 \mathrm{Cj}$ of $\mathrm{Sr}-90$ and $0.062 \mathrm{Ci}$. of pu-238. The 200 year burial limit of ten times less, implies activity limits of $0.15 \mathrm{Ci}$ of $5 \mathrm{r}-90$ and $0.038 \mathrm{Ci}$ of Pu-238, It can be seen that the 100 year limit is more restrictive in this

*Note: in this example, the 100 year limit restricting the total activity at burial of Ru-106 is purely acadents'. Ru-106 has a one year half life and therefore one could bury $7.5 \mathrm{x}$ $10^{26} \mathrm{Ci}$ of $\mathrm{Ru}-106$ and at 100 years be within the activity limit for that drum. 
case involving isotopes of longer half lives although they both are less than 100 years.

For wastes in acceptable containers falling above these immediate and 100 year limits, isolation is required. Wastes destined for isolation from the environment should be divided into two subgroups depending on decay heat generation.

This type of scheme has merit both from a regulatory standpoint and also from the operational standpoint. Again the numbers on limits were rather arbitrary and careful study will te needed prior to establishing these limits.

\subsection{Proposed Waste Classification System - 2}

The classification system described here was developed to provide the maximum in utility with complete operational coverage.* The system thust satisfy the regulatory requirements and should not only be consistent with existing operational systems for hazardous materials, but should blend into them. The classification of a particular material should not chenge as it moves through an operational system unless the hazard associated with it changes. The sysiem must be readily applicable to all radioactive materials.

\section{Extent of System}

The primary consideration of the classification system was to serve the regulatory needs for ladioactive wastes. There is a real need tc move back into the fliel cycle in order to provide a system consistent with operation of the various processes in these plants. Wastes are generater at each point in the fuel cycle. The radioactive properties which define the hazard of radioactive wastes are also characteristic of many other materials in the fuel sycle, in the nuclear

Michael 5. Karol, University of Arizona, NRC Contract \#AT (49-24)-02-05. 
industry in general, and in the entire range of other activities using radioactive isotopes. Thus the inclusion of these materials is virtually autouatic in a system designed to meet operational needs by use of the properties and characteristics of radioactive nuclides.

\section{Systen Design Considerations}

The u-ility of the classification system in meeting regulatory neeis requires the system to relate the characteristics cf the wastes to tine hazarde to be controlled. These characteristics inc lude:
1) Magnitude of the penetrating radiation
2) Hazard Index
3) I fe of hazarc
4) Mobility of the material

In addition, the operational requirements must be recognized so that the operatiors may respond to the precautions inferred by the classification.

The operations that will be aifected include:

1) Cherical processing operations

2) :Tanding operations

3) Zmergency responses (e.g., during a fire)

4) Transportation

5) Waste management - disposal or storage emplacement Detailed :onsideration of these factors leads to certain requirements or roperties of the waste clasification matrix. These are:

1) Simplicity - the system must provide ready classjicication, the classes must be easily recognized and the action implied by the classificatiun readily cefined and implemented without ambiguity. 
2) Useful - the system must provide information needed in operations and regulations.

3) Complete - the system must include all hazarcous radioactive materials.

4) Flexible - the classification system should permit changes in the classification of a material whose hazard has changed and it shuuld also be ile to incorporate changes required by changes in regulat,ons, policy, hazard assessment or by new technology.

5) Multilevel - since different properties aiffer in operational importance for different operations, it is not necessary to have all properties icentified for each. A simpler system for these operations can be provided by incluaing different levels of classification.

6) Precise Definition - Eaci class will be designated by a roman numeral and each subclass by one or more letters.

\section{Primary Categories}

The primary categories provide operating and control information needed in the conduct of each of the operations. These relate to the handling requirements, primarily. "'hey are distinguished by the need for cooling, for shielding, and for coping with an existing biological hazard. The most intense of the radioactive materials are those that require cooling. All such materials require shielding and present a large biological hazard. The next less hazardous materials are those requiring shielding but no cooling. The next lower category is that which does not require shielding jut contains material with 3 radioactive hazard if ingested or inhaled. These categories are sumarized in Table 4.l. 
Table 4.1

\section{Waste Classification Categories}

\begin{tabular}{clc} 
Symbol & \multicolumn{1}{c}{ Category } & Criteria \\
I & Requires cooling \& shielding & $400 \mathrm{~W} / \mathrm{m}^{2}$ \\
II & Requires shielding & $200 \mathrm{mr} / \mathrm{hr}$ surface \\
& & $10 \mathrm{mr} / \mathrm{hr}$ a $0.9 \mathrm{~m}$ \\
III & Requires no shielding & would exceed MPC \\
& & if released \\
IV & Requires no care & (innocuous)
\end{tabular}

An additional category has been suggested for materials that would be diluted below MPC in leaving the controlled area. If adopted, these would be IV and innocuous becomes $V$.

\section{Subcategories}

Subcategories are needed in order to delineate the other factors and properties of concern. One of the mos's important of these relates to the duration of the hazard. The hazards due to radioactive materials are complex, depending on many physical, chemical, and physiological phenomenon, but they have been quantitatively defined by other authorities so that we may use their definitions. We need only consider the changes in hazard occurring with time. Each isotope decays in a precisely defined manner so that the rate of decrease or growth of each radioisotope and its attendant hazard can be readily calculated. Accurate approximations for certain groups of isotopes such as those from the fission process are also available. We then define a subcategory which classifies the wastes according to the time the material stays within a category. When this time is exceeded it will then drop into the next lower category. This particular subcategory has a special meaning for waste management regulations in that, it is probably the principal criterion for distinguishing between 
wastes that may require disposal with assured permanent isolation from the biosphere, and those that may safely be disposed of with less severe restrictions. The time required for the radiaactive hazard to decrease to acceptable levels, if short with respect to the anticipated duration of effective management control, would permit the less restricted emplacement system. Radioactive materials that would exist as serious hazards for times that are long compared to the anticipated duration of effective management control would probably be placed in geologic isolation or in some other system isolated from the biosphere. Note that the Transuranics when treated as wastes would be included in tris latter subcategory. Other long-lived isotopes, however, may also be included, even some of those with "infinite" half-lives, the stable isotopes, if sufficiently toxic.

The next subcategory defines the physical state or mobility of the waste material and the final subcategory determines whether or not treatment is required for some regulatory consideration. These subcategories are summarized in Table 4.2. 
Table 4.2

\section{Waste Classification Subcategories}

\section{Symbols}

a

b

c

d

s

m

$1 \cdot$

8

$t$

n

e

f*

\section{Subcategory}

Life time for changing cate-

gory. Note: An alternate

definition could be life

time till waste leaves cate-

gory III (becomes innocuous).

Solid

Mobı1

Liqquid

Gaseous

Treatment

No treatment

Explosive

Fissile

\section{Criteria}

$<10$ yeat

10-100 year

100-1000 year

$>1000$ year

Immob1le

Will disperse or become airborne if contalner is spllled

Will flow onto a flat surface from a small hole

Will mix with the atmosphere thru a small hole

Must be converted to another form before further processing

Not chemically stable Special nuciear waterials

* May be added if desired for completeness but waste materials other than the transuranics should have no significant fissile content. 


\section{Waste Classification System}

A symbol consisting of several letters can be used to identify the various categories and subcategories. These are sumnarized in Table 4.3.

Table 4.3

\section{Viste Classification}

Symbol

I. $\left[\begin{array}{lll}a & s & t \\ b & a & t \\ c & 1 \\ d & g\end{array}\right]$ e

II. $\left[\begin{array}{lll}a & s & t \\ b & m & n \\ c & 1 \\ d & 8\end{array}\right]$ e

III. $\left[\begin{array}{lll}a & s & t \\ b & \text { in } & n \\ c & d \\ d & g\end{array}\right]$ e

IV.

\section{Description}

Anv material with sufficlent radioactivity to require cooling. The time required before it become's II type is shown by $a, b, c$, or $d$. The physical state is shown as $s, m, 1$, or 8 . The need for treatment is $t$ or $n$ and the explosive nature is blank if chemically Inert, e if a potential hazard.

Any material with sufficient radioactivity to require shlelding. The other elements are as described above.

Requires control but no shlelding$a, b, c$, or $d$ now become the consideration for complete release. Other elements as described.

A material without hazard.

The system can be illustrated by classifying a few materials.

1. Liquid waste from fuel reprocessing which includes the unburaed transurantcs, as it is stored on-site for eventual solidification.

$$
\begin{aligned}
& \text { I }(a, 1, t) \rightarrow \text { remains in category I till } 1985 \\
& \text { II }(c, 1, t)-\text { remains in category I } \text { till } 2100+3000 \\
& \text { III }(d, 1, t)+\text { remains in category III till ? }
\end{aligned}
$$

Upon solidification this becomes

$$
\text { I }(a, s, b) \text {, etc. }
$$


$\therefore$ Filters containing only $131_{1}$

II $(a, s, n)$

A number of facets of the suggested system are arbitrary and can be adjus ted to tnclude other considerations or to improve overall consistency,

The following figure is a reduced schemetic of the Waste Classification system. 
Figure 4.2. Waste Classification system - 2

Radioactive waste

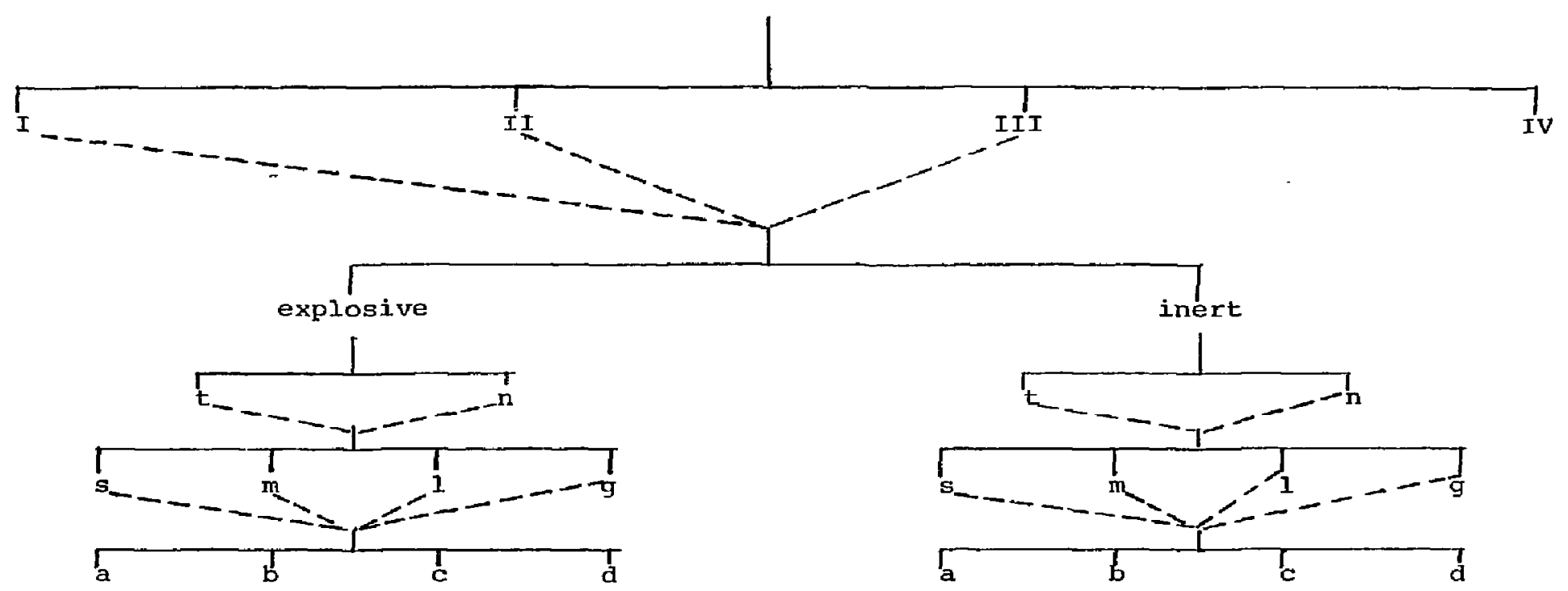




\subsection{Proposed Waste Classification System - 3}

Briefly sketched out, the following simple classification system is based on themal and radiation properties of the wastes. (See Figure 4.3)

Thermal - Radiation would include current wastes:
$\begin{array}{ll}\text { Hot } & \text { Hot } \\ \text { Cool - Hot } & \text { "hulls" } \\ \text { Cool - Cool } & \text { "low level waste" }\end{array}$

Figure 4.3, Waste Classification System - 3

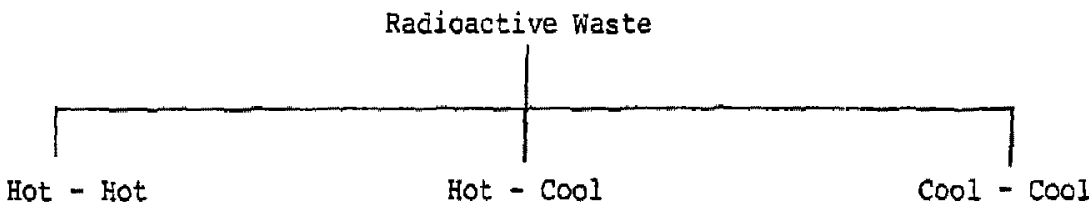




\subsection{Proposed Waste Classification System - 4}

The following rough system and required criteria suggest a format For a waste classification system based on the discussions of environmental criteria. (Figure 4.4 is a schematic representation of this system).

"Release-able": waste satisfying conditions less than those set by "lower bound" criteria. These may be directly released as non-hazardous wastes such as normal trash, garbage, or sewage without further treatment.

"short-duration containment": wastes satisfying the following conditions: 1) greater than those set by "lower bound" criteria where "lower bound" criteria might be developed on the basis of:
a) comparison with natural deposits and natural hazards (re: sone acceptable hazard limit)
b) $\$ 1,00$ per person-rem (re: 10 CFR 50, Appendix I)
c) MPC values less than 10 CFR 20 MFC limits.

and 2) with hazarc durations less than those specified by "middle bound" criteria.

"isolation": wastes satisfying conditions greater than those set by "lower bound" criteria but with hazard durations greater than those set by "midale bound" criteria which might be developed on the basis of:

1) WAsH-1539 (Inventory committment as discussed in WASH 1539)

2) between 100 years and 1000 years (re: $W$. A. Rodger, Critical Evaluation of the Limit of Transuranic Contamination of Low Level Wastes, August 1975 , Nuclear Safety Associates, Bethesda, Maryland). 
Figure 4. 4, Waste classification system - 4

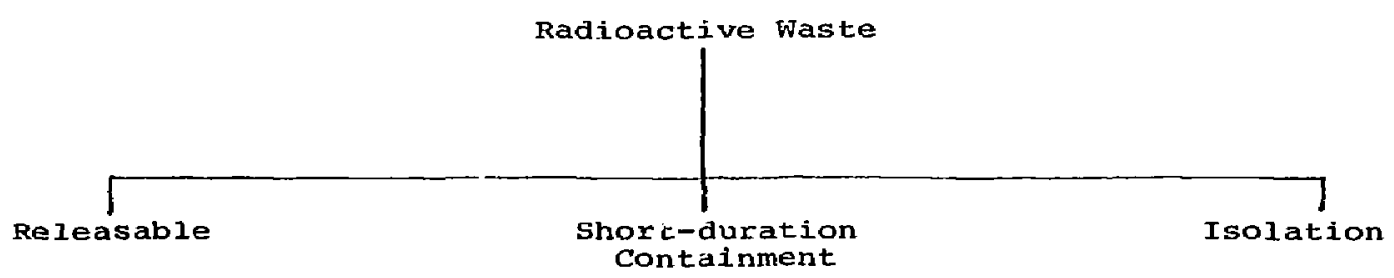




\subsection{Proposed Waste Classification System - 5}

Early on, at the Reston meeting of TAP, a waste classification system based primarily on two disposal modes was suggested. Wastes would be classified first as:

1) those wastes to be disposed of at shallow land burial sites and

2) those wastes to be disposed of in deep geologic Eormations.

Those wastes destined for deep geologic disposal would be further categorized as high heat or low heat wastes. Low heat wastes should further be classified as those requiring shielding and those not requiring shielding. Figure 4.5 is a schematic of this system. 
Figure 4. 5 wasto classification System - 5

Radioactive Waste
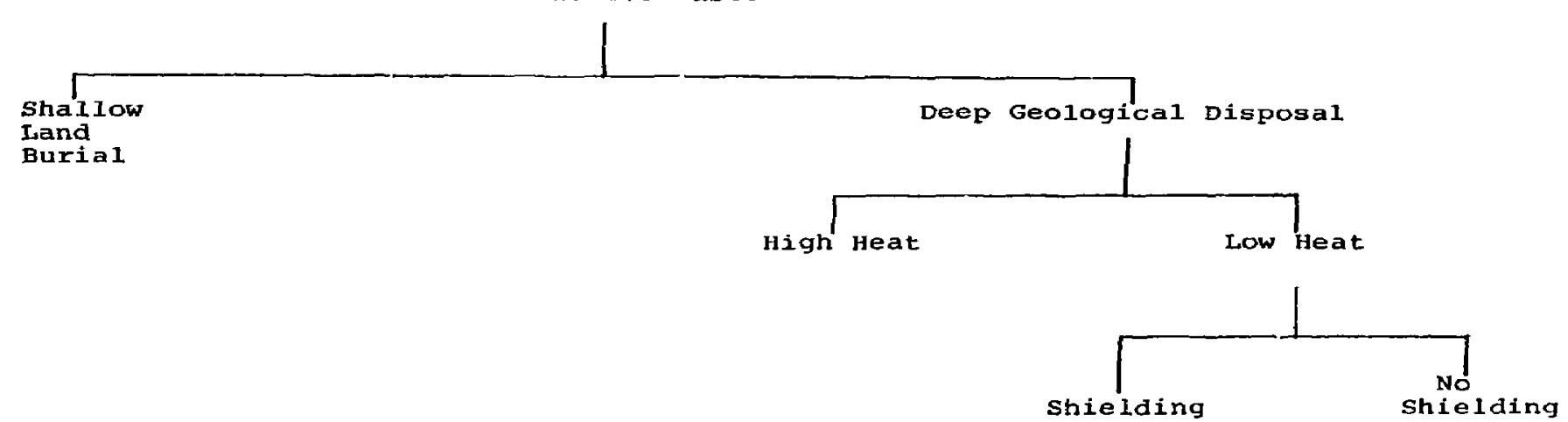


\subsection{DISCUSSION}

\subsection{Introduction}

A review of Chapters 3 and 4 indicate that all twelve of the classification systems presented are based on one of the following general conditions:

(a) The source of the waste

(b) Physical characteristics of the waste

(c) Disposition of the waste.

Radioactive waste can be labelled at its source. As an example, waste material could be classified as reactor wastes, spent nuclear fuel, reprocessing wastes, or fuel fabrication wastes. Further, reprocessing wastes could be referred to as spent fuel cladding, liquid process wastes, and general process trash. Such a classification system does not provide any information about the nature of the radioactive waste or the means of handing, processing, or disposal. Sucri a system does not appear to facilitate the formulation of waste management regulations.

Most of the classification systems reported in the literatura are based on the physical characteristics of the radioactive waste. For examole, the IAEA reconmended in 1970 that radioactive wastes first be classirified as solids, liquids, or gases. The liquids and gases were then subdivided by activity levels, curies per milliliter, or curies per cubic meter. The solid wastes were subdivided by surface radiation dose rate, rads per hours. The Technical Advisory Panel generally felt that a functional 
waste classification system could be divelcped based only on physical characteristics.

There are many different ways to dispose of radioactive wastes. It appears that some common features of various disposal options leads to groupings into broader categories of waste disposal methods. These features include the degree of containment achievable, the degree of isolation and the extent of social comitment required for each disposal option. The Techrical Advisory Panel also ayreed that a functional waste classification system should be developed based on disposal methods. (Disposition).

Having reviewed and discussed the various ciassification systems, it appeared worthwhile to narrow the field to two prototype systems, each having distinctive attributes. These are:

- Syster I: A multicompartmented classification system which provides detailed descriptions of the characteristics of wastes in each category, such a system would provide guidance for all operational aspects of handling the waste.

- System II: A three-category classification intended to give guidance as to final disposal of waste. It would provide that information necessary for transfer of waste from the generator to the disposer of the waste. Information necessary for other waste handling could be given in in-plant operational procedures.

\subsection{System-I, Classification System Based on Waste Characteristios}

The intent of this classification system is to describe a radioactive waste with an efricient notation conveying the important waste characteristics. Such a system can be used for all phases of waste management. 
The important characteristics of the radioactive wastes denoted by this classification system are as follows:

(a) Magnitude of radiation intensity

(b) Physical state

(c) Hazard index

(d) Duracion of hazard

\section{Radiation Intensity}

The primary level of classification is radiation intensity. Four levels of intensity have been as-igned so provide information on the projected need for forced cooling and/or ranges of shielding required. An example of how these categories can be defined is as follows:

$\begin{array}{cll}\text { Categories } & \text { Reguirements } & \text { Ci/m } \\ \text { I } & \text { Cooling and Shielding } & \text { Above } 10^{4} \\ \text { II } & \text { Shielding } & 10^{-1} \text { to } 10^{4} \\ \text { III } & \text { No Shielding } & 10^{-6} \text { to } 10^{-1} \\ \text { IV } & \text { No Care } & \text { Below } 10^{-6}\end{array}$

These general groupings are only guides. It should be recognized that in very large configurations or in containmert systems with good insulation, Group II materials may also require some type of cooling. It is also possible to have waste materials that have a Group II level of intensity but require little or no shielding, as might be the case with Pu-238 or Pm-147 contaminated material. is indicated these primary categories are set forth only as examples. The intensity of radiation can also be definsd in units of watts per cubic meters or by any of several other anezgy per volume units. 


\section{Physical State}

The next level of classification logically falls to physical state of the waste. The simple notation of $I, G$, and $s$ can be used to indicate liquics, gases, and solids, respectively.

\section{Hazard Index}

The third level of classification or subcategory would be by the hazard index appropriate for each physical state. The most commonly used hazard index are $M P C_{W}$ (a) for liguids, $\mathrm{MPC}_{a}{ }^{(b)}$ for gases and MPQI (c) for solids. An example of how these hazard indexes can be applied to define classes of radioactive materials is as follows:

\section{Hazard Index Subcategory}

A.

Liquids

Gases

Solids

B.

Liquids

Gases

Solids

c.

Liquids

Gases

Solids

\section{Range of Hazard Index}

From $M P C_{w}$ to $10^{4} \mathrm{MPC}_{\mathrm{w}}$ From $\mathrm{MPC}_{\mathrm{a}}$ to $10^{4} \mathrm{MPC}_{\mathrm{a}}$ From MPQI to $10^{4} \mathrm{MPQI}$

The number of subcategories can be expanded and the ranges of hazard indexes can be adjusted to suite specific operational or regulatory requirements.

(a) ${ }_{\text {MPC }}$ - Maximum permissible concentration for water as defined by 10 CFR 20 Appendix B, Table II.

(b) MPC - Maximum permissible concentration for air as defined by 10 CFR 20 Appendix B, Table II.

(c) MPQI - Maximum permissible quarterly intake is defined as $\left(M P C_{w}\right)\left(2 \times 10^{5}\right)$. Reference AIChE, Proposed Definition of Radioactive Waste Categories, June 7, 1967. 
It should be noted that the use of maximum permissible concentrations as a hazard index is not a direct measure of dose to man. Specific pathways to man must be examined in order to address the question of dose to man. In the case of radioactive iodine, concentrations of iodine below MPC can be concentrated to above MPC levels by the food chain.

\section{Duration of Hazard}

The final subcategory is the notation of duration of hazard. The duration of hazard provides information about the length of time required for the hazard index to drop below levels defined by subcategory $A$. The duration of hazard is a function of both radionuclide concentration in the waste and the half-life of the radioactive material.

An example of duration of hazard subcategories is as follows:

\section{Duration of Hazard Subcategory}

a

b

$\mathrm{c}$

d

\section{Time Required to Reach Hazard Index Subcategory A}

$<10$ years

10 to 100 years

100 to 1,000 years

$>1,000$ years

Again, it should be noted that the range of hazard durations in these specific groupings are examples. More subcategories, or different time periods may be appropriate for regulatory needs.

The classification system then represents a certain waste with the notation of four symbols, and is schematically represented in Figure 5.1. As an example, high-level liquid 
SYSTEM I - RADIOACTIVE WASTE CLASSIFICATION

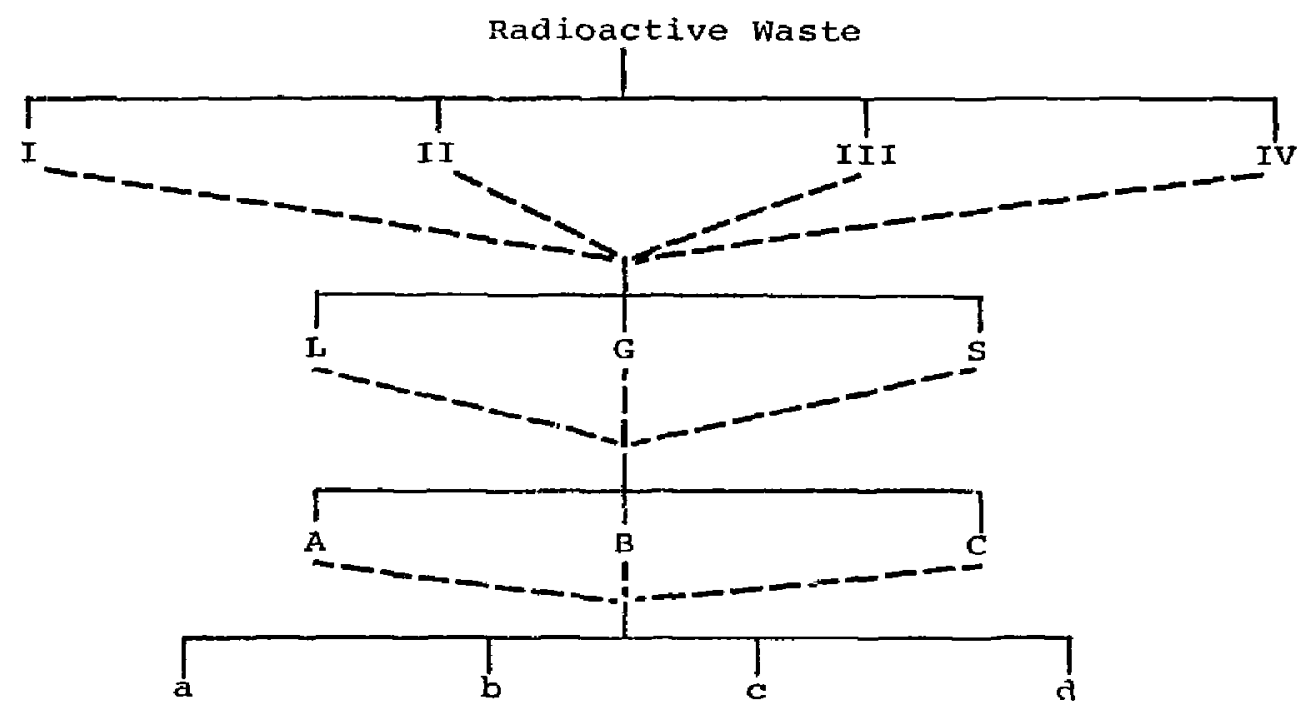

Figure 5.1 
waste from a nuclear fuels reprocessing facility would be referred to as (ILCd). Intermediate-level liquid waste from a reprocessing facility would be (II LCC.), or (II LCC), depending on the plutonium concentration. Similar statements can be made about other types of radioactive waste with known compositions. If desired, other notations can be added to the system to denote special features of the waste such as a large content of fissile material, unusual mobility, or chemical stability.

This waste classification system is limited to the description of radioactive wastes. The system can be used to identify radioactive wastes at any point in the generation of such wastes. It does not imply any guidelines for the development of regulations for handling and disposal of radioactive wastes or in the formulation of waste managament criteria. These considerations might appropriately come into play when specific hazard indexes, hazard durations, and radiation intensity definitions are developed. For a descriptive waste classification system to be useful in makiny waste management decisions, the waste characteristics critical to the system must also be those critical to waste management decisions.

\subsection{System II - Classification Sustem Based on Characteristics of Disposal Means}

The final disposal of radioactive wastes can be considered to be the most important operation in any radioactive waste management program. It is also the operation that requires the most definition. Therefore, if a waste classification system could be formulated on the basis of disposal options, it would provide information and guidance allowing the maximum flexibility for the waste generators implementation of waste management programs. 
There are several methods for disposing of radioactive material that have been utilized in the past and several more methods suggested for the future. It is, therefore, very important that a radioactive waste classification system basec on disposal be broad enough to include any means of disposal.

The list of suggested methods for management of radioactive waste includes the following:

- Direct discharge or dispersal to either the atmosphere or surface water

- Storage until the radioactive isotopes have decayed to an innocuous level

- Shallow land burial

- Ocean dumping

- Deep geological emplacement

- Ice cap emplacement

- Extraterrestrial disposal

- Ocean disposal (Seabed burial)

- Deep well injection

- Shale fracturing

\section{Common Features}

Various statements can be made about the degree of containment, degree of isolation, and degree of social comitment each of these disposal systems provide or require for waste disposal. As an example, direct dispersal to the environment provides no confinement, while deep geological emplacement should provide essentially complete containment for geological periods of time. The degree of social comnitment refers to such ongoing functions as record keeping, maintenance, and system and environmental monitoring. Such management systems as surface storage, or 
shallow land burial can be expected to require significant social and resource commitment for some period of time. This would include area security, repair of containment barriers, environmental monitoring, and record keeping, This social commitment would extend past the period of time that the disposal facility is actually receiving radioactive material. In contrast, after the operational phase is discontinued, deep geological disposal will require minimal social commitment to the extent of preventing mining or drilling in the disposal area.

It is, therefore, possible to formulate a waste classification system based on disposal methods without being limited to the means of disposal. All disposal systems can be placed in one of the following three categories:

(1) Disposal by direct dispersal to the environment

(2) Disposal by methods requiring social comnitment

(3) Disposal by methods that provide long-term isolation.

The following breakdown or categorizing of specific disposal methods would be as follows:

I. Dispersal to the environment
a. Stack discharges
b. Liquid effluent discharges
c. Solid disposal to sanitary land fills

II. Disposal methods requiring social comitments
a. Shallow land burial
b. Storage near surface
c. Ocean dumping
d. Deep well injection 
III. Disposal methods providing long-term isclation

a. Deep geological emplacement

b. Ice cap emplacement

c. Extraterrestrial disposal

d. Ocean disposal

e. Shale fracturing

The categorizing of the above disposal methods does not imply that these methods are technically sound or acceptable. The methods listed are ones that have been proposed or utilized in the past.

Having categorized the various radioactive waste disposal systems, how does that help categorize radioactive waste materials? The procedure for classifying waste materials is to review the interfaces or breakpoints between dispersal and methods categorized as requiring social commitment, and between methods requiring social comitment and methods providing isolation. Figure 5.2 is a schematic of the classification system. Figure 5.3 lists a series of considerations which may be important in deciding what type and amount of radioactive waste can be disposed of by the various waste disposal methods. The purpose of the list of considerations is to provide the broadest possible viewpoint for the regulatory agencies charged with the preparation of waste management criteria and regulations.

The first eleven considerations listed on Figure 5.3 relate to the waste management criteria that would dictaice whether a radioactive waste material could be dispersed or whether it would have to be contained. The Technical Advisory Panel's opinion was that the goal of any waste management program was to limit the potential radiation dose 
SYSTEM II

RADIOACIIVE WASTE CIASSIFICATION

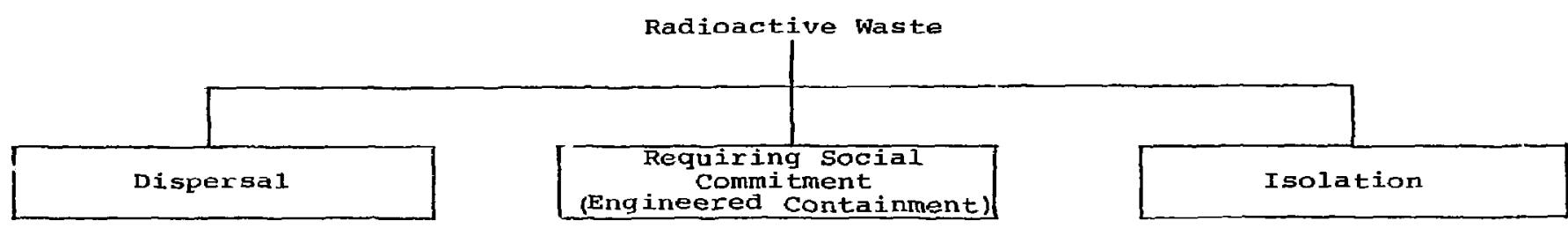

Direct discharge to

either the atmosphere

of surface water
Shallow land burial

storage neax surface

Ocean dumping

Deep well injection
Deep geological disposal

Ice cap emplacement

Extraterrestrial disposa?

Ocean disposal

Shale fracturing

Figure 5.2 
Considerations in Determining Disposal

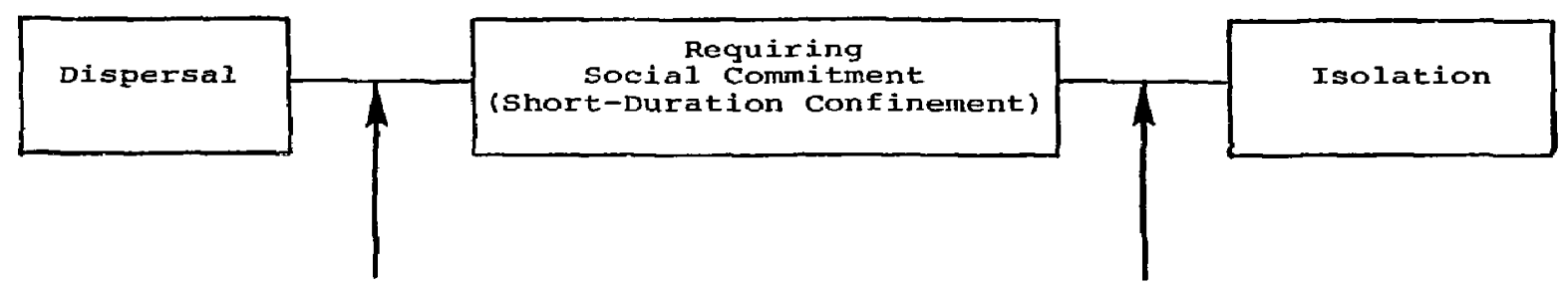

1) Health Effects

2) ALARA

3) Man-Rem Total

4) Cost-Effectiveness

5) Present Regulatory Guides ICRP and NCRP

6) Past Weapon Tesi Maximums

7) EPA (25 MF Maximum)

8) Natural Background

9) Detectability

10) Deterioration of Resource

11) Man-Rem/Mw Day
1) Projected Effects on an Intruder

2) Inventory commitmerst to a Specific site

3) Social stability

4) Inventory Release Rates

Figure 5.3 
to man. Nine of the first eleven considerations deal with various aspects of the dose-to-man question and, therefore, are closely related.

There are several different types of criteria that could be established to limit the type and amount of radioactive material that could be released to the eivironment by dispersion. As an example, absoiute values for one or more of the following could be set.

- Total health effects

- Total person-rem

- Person-rem per unit power production for electricity generated

- Cost-effectiveness guideline

- Maximum credible dose to any individual or critical group.

Any discharge to the environment by dispersal which exceeds a predetermined value would either have to be captured or treated. The resultant radioactive material from such a capture or treatment operation would have to be contained or disposed of by one of the two categories of waste containment methods.

A second means of formulating waste management criteria would be to utilize existing regulations and regulation guides. As an example, present ICRP and NCRP standards could be used to establish limits for materials that could be dispersed. Also EPA's proposed limit of a maximum of 25 millirem exposure per year from nuclear fuel cycle operations including waste disposal to any one person could also be used to Iimit the quantity of radioactive material that could be dispersed to the environment. 
Another approach is to establish an acceptable personrem cost-effectiveness value. An example would be 10 CFR 50 Appendix I, which establishes a value of $\$ 1,000 /$ person-rem. All individual exposure that could be eliminated at a cost of a $\$ 1,000 / p e r s o n-r e m$ or less would be. A different approach is to establish a regulatory philosophy that the dose to man from the dispersal of radioactive material will be maintained at a level that is "as low as is reasonably achievable." Such a philosophy is already implied by paragraph 20.1 (c) of $10 \mathrm{CPR}$ part 20 . This guidance would have to be translated into practical criteria, Previous examples in terms of dellars per man-rem or man-ren per Mwe year may suffice. Perhaps some other approach might also be in order.

Two of the eleven considerations listed on Figure 5.3 which do not deal directly with dose to man are detectability and deterioration of resources. There is a strong feeling in some quarters that no level of dispersal of radioactive material to the environment is acceptable. In the case that "no release" be defined as a waste management criteria, then essentially the amount of material that can be released by dispersion would be Iimited by our ability to detect radioactivity. A strict literal translation of zero release would preclude any operations which involve radioactivity.

The consideration of the deterioration of resources is primarily addressed to $\mathrm{Kr}-85$ releases which contaminate natural krypton in the atmosphere. A waste management criteria might be set on the basis of accaptable levels of resource deterioration by treating certain environments as potential resource bases. 
A combination of two or more of the above approaches could provide a reasonable method for the development of regulations and waste management criteria. For example, an ALARA regulatory philssophy in conjunction with a cost-effective calculation and a maximum acceptable health effect or maximum single-person dose limit could provide criteria difining what could be dispersed and what would require containment.

The next step is to address waste management sriteria that can be used to determine that type and amount of radioactive material that can be disposed of by the confinment methods and what material must be placed in iso ation. Figure 5.3 lists some of the considerations.

Shallow land burial can be used as an eximple to discuss this second set of criteria. In discussions dealing with shallow land burial, the Technical Advisory Panel generally reached the following concli ions:

- Shallow lana burial should be considered as a disposal method which requires ongoing social commi tment.

- Diring the operational phase and auring the first 100 years following decommissioning of a shallow land burial site some low-level discharge to the environment can be expected. Releases of as high as $1 \times 10^{-6}$ of the total site inventory per year have been experienced in the past.

- The magnitude of these relesses is a function of several factors such as site location, area rainfall, geology, hydrology, engineering features, and operational procedures. Release rates are site specific and depend on these factors. 
- Surfáce geology can change significantly in tins periods as short as 5,000 to 25,000 years. Social and institutional patterns can also be expected to change during these time periods. Therefore, no long-term containment of radioactive material should the expected to be maintained by nearsurface storage or dispostl systems.

- Some rate of release of racioactive material to the environment from radioacts waste thanagement programs is acceptable.

- Given a specific shallow land burial sitc with specific information on meteorology, geology, hyorology, engineering design, and nther appropriate information, it is possible to estimate the amount of radioactive material that woulo be released from that site over a 100-year period.

- A conservative estimate of the du: $\quad$ of social comitment to a disposal site is 1 . ears.

As indicated, these conclusions are based on shallow land burial disposal. But similar statements can be made about storage facilities, ocean dumping, or jeep well injection. Such statements include:

- Degree of containment is procedure and site specific

- Long-term containment (>1,000 years) cannot be assured

- Some estimate of release for various time frames can be made.

In discussing shallow land burial, $T A$ reviewed the possible fate of zadioactive material placed in shallow iand burial. The general opinion was that two tige flames must be considered. The first time frame includes the operational phase of the burial ground and the first 100 years following decomrissioning. The second time frame was after 100 years. 
During the first time frame, release of radioactive material to the environment depends on specific site characteristics, engineering features, and operational procedures. The Technical Advisory Panel generally felt that sufficient data could be obtained to predict the release of radioactivity from a given site within a determined range. It was felt that the release rate can be assumed to be constant for each site, whereas the tctal quantity released is a function of the site inventory. Accidental intrusion during the first 100 years is not considered to be a problem because of site records and security systems.

Therefore, for the first 100 years total site inventory would be the factor that should be controlled and regulated. The same discussion of waste management criteria previsusly presented on dispersal, would apgly to determining acceptable release from a shallow land burıl site.

The second time frame would be after 100 years. It was assumed that no records of the site exist and no security system is operating. It is possible that the site coula become an agricultural area cr part of a potable water supply system. Therefore, the inventcry of radioactive material remaining at the site is important. A detailed analysis of the possible pathways to man from such a site must be done, and a set of waste management criteria must be formulated to define what an acceptable dose to man might be at some time in the future. These criteria for acceptable dose ::o man in the future may or may not be the same as those applied to the present population. 
In addition to the possible exposure to man via the food chain or water, accidental intrusion by man into the site is also possible. Such an intrusion could take the form of drilling, mining, or surface excavation. A reasonable criteria might be that the amount of radioactive material in any one waste package shoula not be high enough to injure someone who $s$ tumbles upon it after 100 years. This consideration would place limit on the concentration of radioactive material per unit volume of waste.

As indicated earlier, actual numerical values for any limit on either inventory or concentration will be method and site specicic. It is important to note that total curies of activity would probably not be the units chosen to define either the inventory or concentration limits. Instead a hazard inoex would be utilized. Inventory limits could be based on the volume of water reguired to dilute the total site inventory to $\mathrm{MPC}_{\mathrm{w}}$ linits. The rsason to choose $M P C_{w}$ as a basis for inventory linits is that the inventory limits are intended to restrict the quantity of zadioactive material slowly released from a given site. The dose to man from the material released is probably by water ingestion or food chain ingestion. Therefore $M P Z_{W}$ is an indication of that potential dose, but not a direct measure.

Other considerations in setting absolute inventory limits is that radioactive materiais decay, therefore the total hazard index for a given site is always changing. Also, during the first time frame corrective actions can be taken if higher than expected releases occur, while during the second time frame release would be assumed to go undetected. Therefore, the inventory 
linits for the first time period may be several times greater than the inventory limits for the second time frame. This would allow large curie quantities of short-lived radioactive isotopes to be disposed of by the second category of disposal methods, but might limit the longer-lived radioactive isotopes. Detailed analysis of the specific disposal method and dis posal site is $\mathrm{r}$ aguired to determine which of the three limits would be contrulling. 


\subsection{CONCERNS AND OPINIONS EXPRESSED BY MEMBEKS \\ OF THE TECHNICAL ADVISORY PANEL}

With few exceptions, members of the Technical Advisory Panel expressed the concern that developing a waste classification systen judependent of disposal mechanisms might result in an ultimately useless system. This concern was expressed primarily with respect to waste classification systems which were based on engineering parameters of the waste form. The thought wes that the disposal mechanisms should be known in order that the correct engineering parameters could be selected for the classification system. An important pitfall to be avoided in a waste classification system is inplying more diffurentiation between methods of treatment, storage or disposal of wastes than is scientifically warranted or technically useful.

Some of the more complex systems, because of the number of categories, appear to have almost as many slots as a complete table of engineering data; but may provide less information than the engineering parameters. For exampie, with two engineering parameters, the nuclide and the concentration, the hazard index characteristic through life can be plotted. Conversely, with some classification schemes, four parameters provioe insufficient data. The choice of the four parameters in system-I was made, hopefully to provide the most pertinent information with regard to waste management problems. This points out the need to develop some foundation in terms of waste management criteria or disposal methous even before a purely descriptive classification system such as system-I can be rigorously developed and defended. 
It was suggested that the formulation of environmental criteria for waste management criteria she uld be the first step in the establishment of regulations.

Several technical cautions arose repeatedly in the meetings of TAP. One that is considered to be answered by System-II is regarding facility decommissioning. While all the various decomissioning wastes, which would be transported from the facility site, can be treated as wastes by either system, the entombed* facility essentially creates a new type of permanent waste site, which is readily classified as a waste requiring social comitments to the waste site.

The questions of enviromental hazards and how best to represent them were a prominent point of discussion. To date the various measures of hazards all appear to have some degree of limitation. The most commonly used hazard index is the measure of the volume of water necessary to dilute variour wastes to the recomended radioactivity concentrations as listed by either ICRP or $10 \mathrm{CFR} 20$ for ingestion in soluble form in unrestricted areas. This hazard incex does

\footnotetext{
*Generally, entombment inciudes removing the uncontaminated areas of the plant and surrounding (or werhaps filling) the grossly contaminated areas with concrete. To reduce the yolume to be entombed, outlying contaminated components may be dismantled and placed inside the structure to be enclosed.

Entombment of nuclear facilities includes the following activities as a minimum: 1) offsite disposal of all solid and liquid radioactive and nonradioactive process materials, 2) controlled public access to site and facility, 3) periodic physical, radiation and environmental surveys and inspections, 4) maintenance and limited operation of lighting systems and fire protection alarms, 5) removal of salvigeable uncontamined equiprent, 6) erection of "permanent" (>100 years) barriers to protect the environment from radioelements, e.g., filling radioactive vessels and cells with concrete, and 7) decontamination of the site.
} 
not directly relate to dose to man but does provide a measure of potential dose. A detailed review of the various pathways of the radioactive material to man must be made in order to accurately evaluate the dose to man.

Concern was expressed about the Iimitation of mathematical models to accurarely predict releases of radioactive material from specific disposal methods. It was suggested that in many cases, basic information required by models was not available.

The panel also felt that a risk analysis should be performed on the various waste management options. The information gained from such an analysis would serve as a guide to both the regulatory agencies and to the designers of waste management systems.

Specific comments from Art Carson can be found in the Appendix. Also, a paper by Dr. W. A. Rodger containing recomended waste management criteria with associated numerical values can also be found in the Appendix. 


\subsection{SUMMARY AND RECOMMENDATIONS}

Reviewing the various classification systems and discussions of the TAP, it appears that for in-plant waste management operations a detailed multicompartmented waste classification system such as described un system I in Part 5 of this report would be in order. System I characterizes a given waste at a specific point in time by several judiciously chosen waste characteristics. Such a systen provides 144 different classes by hich waste may be identified; depenaing on the operational status of a particular waste (i.e., irterim storage, in process or final product form) the crucial charasteristics of the waste may be different. As an example, for high-level liquid waste in interim storage it may be nost important to know the physical state and the radiation intensity. For a solidified waste product, it may be important to know the duration of hazard of that waste since it may be economically advantageous to store such waste prior to its shipment and ultimate disposal. The emphasis placed on any given waste characteristic wi].l ultimately be based on waste management criteria and final disposal nethods. This system allows the operator to economically optimize waste management procedures. For example, it allows for storage of waste at the operator's discretion until such time that it can decay to levels that it might be safely disposed of by some less expensive means, This would be an acceptable practice as long as the waste remains under the operator's responsibility. However, for purposes of final disposal or interfacility transfer, a commonly understood and acceptea system of classification might be nore appropriate, since the in-plant classificatior system would be to a large extent at the discretion of the facility operator, and would be largely 
responsive to his own particular operations and problems, it might not serve as a proper basis for general regulation. System I is, therefore, presented here only as a suggestion for a thorough and comprehensive in-plant waste classification system, but it probably would not serve as a suitable basis for general regulation.

For purposes of ultimate disposal and interfacility transfer, a waste classification system as described under Syster II of Part 5 would be more appropriate. System II is a classification system based on considerations necessary in formulating disposal decisions. Since the principal concerns regarding radioactive waste as a potential radiation exposure to man and the final disposal of such a waste, System II is immediately useful in formulating waste management criteria and is useful in classifying waste for final disposal decisions and regulations.

It is recommended that a waste classification system as described in system II provide the basis for NRC regulations. Prior to promulgation of such regulations it would be necessary to define quantitative criteria for delineating between the waste categories. Specifically, waste requiring isclation (high level), that requiring confinement for periods where social commitment can be assured (low level), and waste whose hazard is so low that direct dispersal to the environment would be considered acceptable.

Some principles and guidelines for quantitative definition of waste categories have been presented in this report. However, further study and deliberation will be necessary to establish a firm and defensible basis for quantitative delineation of waste categories. 
REFERENCES

1. International htomic Energy Agency, "Standardization of Radioactive Waste Categories," Technical Report Series No. 10, Vienna, Austria (1970).

2. Gera, Ferruccio. "The Classification of Radioactive Wastes," Health Physics, Perganon Press, (1970), Vol. 27, pp. 113-121.

3. American National Standards Institute, "Categories of Radioactive Waste," ANSI-N525, Draft No. 2, (1968).

4. U.S.A. Standards Institute, "Proposed Definition of Radioactive Waste Categories," sponsored by the American Institute of Chemical Engineers, (1967).

5. U.S, Atomic Energy Administration, AEC Manual, Part I, Chapter 0511, "Radioactive Waste Management," Appendix 0511, lapproved September 1973 \}.

6. Karol, Michael s. "Operational Classification of Radioactive Waste, "University of Arizona, supported by NRC Contract $\frac{\pi}{\pi} \operatorname{AT}(49-24)-02-05$. 
APPENDIX A

TECHNICAL ADVISORY PANEL

MEMBERS

AND

PARTICIPANTS 
APPENDIX A

Technical Advisory Panel Members and Participanis

Gary R. Bray

Sara $K$. Julin

Frankie Deisher

Hugh Kendrick

Science Applications, Inc.

8400 Westpark Drive

McIean, Virginia 22101

Art Carson

General Electric Company

175 Curtner Avenue

San Jose, California 94125

Jerry Cohen

University of California

Lawrence Livermore Laboratory

P. O. Box 808

Livermore, California 94550

Paul R. Fenske

Desert gesearch Institute

University of Nevada

Center for Water Resources Systen Research

Reno, Nevada 89507

Steve Garner

Nuclear Engineering Co.

9200 shelbyville Road

Louisville, Kentucky 40222

Jack Healy

Ios Alamos Scientific Laboratory

H-Division, Mail Stop -690

Los Alamos, New Mexico 87545

William Eolcomb

Environmental Protection Agency (AW-459)

401 street, S.W.

Washington, D.C. 20460
(703) $821-4552$

(703) $821-4428$

(703) $821-4554$

(.03) $821-4550$

(408) 297-3000 Ext. 5430

(415) 447-1100 Ext. 8821

(702) $784-6955$
1505) $667-5514$

(202) $755-4863$ 
Donald Jacobs

Oak Ridge National Laboratory

R. 0 . Rox $x$

Oak Ridge, Tennessee 37830

Michael Karol

University of Arizona

Department of Nuclear Engineering

Tucson, Arizona 85721

พ. C. King

University of California

Lawrence Livermore Laboratory

P: 0. Box 808, Mail Stop 5-518

Livermore, California 94550

\section{James Malaro}

U. S. Nuclear Regulatory Commission

Office of Nuclear Materials Safety and Safeguards

Weshington, D. C. 20555

G. Lewis Meyer

U. S. Environmental Protection Agency

(AW-459)

401 M Street, S.W.

Washington, D.C. 20460

R. I. Newman

Allied-General Nuclear Services

Box 847

Barnwel1, South Carolina 29812

E. D. Worth

Nuclear Fuel services

1111 University Blvd.

Silver Spring, Maryland

Roy G. Post

University of Arizona

College of Engineering

Department of Nuclear Engineering

Tucson, Arizona 85721

Jchn E. Razor

Nuclear Engineering Co.

P. 0 . Box 146

Morehead, Kentucky 40351
(615) 483-8611 Ext. 3-1592

(602) $884-1300$

(415) $447-1100$ Ext. 3870

(301) $492-8180$

(202) $755-4863$

(803) 259-1711

(301) 649-1688

(602) 298-0756

884-1229

(606) 784-6611 
Walton A. Rodger

Nuclear Safety Associates

5101 River Road

Bethesda, Maryland 20016

Harvey $F$. Soule

U. S. Energy Research and Development Administration

Division of Nuclear Fuel Cycle and Production

Mail Stop Bl07

Washington, D.C. 20545

Art Toy

Lawrence Livermore Laboratory

2. 0. B0X $808, L-518$

Livermore, California 94550

Verne Trevol row

Argonne National Laboratory

9700 South Cass Avenue

Argonne, Illinois 46309

Bruce Wachhol?

U. S. Energy Research and Development Administration

Division of Biological and Environmental Research

Washington, D.C. 20545

R. F. Williams

Electric Dower Research Institute

3412 Hillview Ave.

P.O. box 10412

Palo Alto, California 94303
(301) $986-1310$

(202) $353-3253$

(415) 447-1100 Ext. 3873

(312) 739-7711 Ext. 2539

FTS $"$ ? 253 :

(301) $353-3394$

(415) $493-4800$ 


\section{APPENDIX B}

PART 173.389

OF TITLE 49

CODE OF FEDERAI REGULATIONS 


\section{Code of Federal Regulations}

$\$ 173,389$

\subsection{Radioactive naterials; definj- tion.}

For the purpose of Parts 170-189 of thls chapter:

(a) "Fissile radoactive to a ter $\mathrm{f}$ a l" meane the following materiai: Plutonlum-238, plutontum-239, plutontum241. uranium-233, or urandum-235, or any material contalntne any of tho foregolng matertals. See $5173.390(a)$ for excluslons. Fisstie radioactive material packages ate classiffed according to the controls needed to provide nucleat cttIcailty safety during transportation as Iollows:

(1) Fissile Class 1. Packages whlch may be transported in unilmited numbers and in any arrangement, end which requlre no nuclear critlcality safety controls during transfortalín. For purposes of uuclear critlcalicy safety control, a transfort ludex is not asstgmed to Flssile class I packages. However, the externa! radiation leteis may recuire a transport Index number.

(2) Fissite Class $I$. Packazes whlch may be transported together In any artangement but in niambers which do sot exced nn asbresate transport lndex of 50. For purposes of wuciear criticailts safety concrol, Inditdual pachages may have a transport Index of not less than 0.J and not more than 10. However, the external radiation levels may require a hlghar transpert index nunber but not to exeed 10. Such sh!pments require no ruslear chtleality salecy control by the hipper dutting transportation.

(3) Fisstic Cless IJT. Shipments of packages nithlch do not mete the reatufremeni- of Flsslie Class I or II and aituch ere controlied to provide nuclent critlcollty salcly in transportalion by specinl errangelatents betwien the shlpper and the catrier.
Hore 1: Jronlam-235 ezlats onds In cozblastion witb yartous percestapes or traDitum-234 inad utanlum-238. "Ftestle radlocotle material" as applled to liradum-235 cafers to the absunt of uraulum-235 actually conenined to the total quanity of uzealum belas transported.

Fore 2: Radionctiqc Diateral may constat of trif tures or Asstle and pon-firstle indionuelldss. "Flesile rndlone live mater!al" tc:ors to the amount of plutonlum-23B. plitontum239, plutonl um-241. utnalum-2j3, uranlum235. or ans comblaston thereor actuall contilned th the mixture. T20 "radions:17. Ity" of the muxture consists of the wotal activity of both the nssllo and panassils mdtonuelides. Ali mixtures containicg "Derile meteris" shnif ba sidject to 173390 .

(b) "Large quantly radioact!ve me:rlals" means a quartity the eG6regate radianctivity of which exceeds that spec!hed as follows:

(1) Grotus I or II (see parzgrajh (h) of thls section) radionuclides: 20 clures.

(2) Grovps III or IV radionuclides: 200 curies.

(3) Group V radionuclides: 5,000 curles.

(4) Groups VI or VII Eadionticlldes: 50.000 curles.

(5) Specinl form meterlal: 5,000 curies.

(c) "Low spectfic actlvity materia"" means any of the followitn:

(1) Iranium or thorlum ores and physlce] or chemlcs: concentrates of those ores:

(2) Unirradiatca natural or gepieted uranlum or unirradited natura! thoHum:

(3) Trttum oxide in aqueous solitions proilded the concentration docs not exceen 5 millleuries per wll!hiat:

(4) Materlas in ridus the acturty is essentially un'fortily cistributed nod in shich the estimated arerafe concentra. lon pes Eram of contents docs not exceed:

(1) 0.600I nillfeuttes of Group I (see $\$ 173.389(h)$ ] radlonuchdes; or

(il) 0.005 milticurtes of Oroup IJ radiontuclldes: or

(115) 0.3 millicumes of Groups ILI or IV radlonuclides.

Nore: This includes, but in noc llmited to. matesjals of low rndloartirlty cosecntentson. such as realdues or solutlols from cilestrical processing: wastes such as betlliting rubble. meial. Fond. and fubrle acrop. Elnsware. proce and cardubard: colld or liquld pingt waste. Gludges. Whe abich.

(5) Objecis of nonfadlonctive hinterial extermally comtaminnted will radinactive materlat, brovhled that the 
radloactlve material b not readlly dis. persible and the surface contamination when sveraced over an aies of 1 square meter, does not exceed 0.0001 bullicurte (220,000 disintegrations per minute) per square centimeter of Group I radionucildes or 0.001 millicurle $(2,200,000$ disintegrations por minute) per square -centlmeter of other radionucildos.

(d) "Normal form radloactive ma. terials" means those which arc not speclal form radioactlve materlals. Normal form radjoactive materdals are grouped Into liutsport aroups (sec paragraph (b) of this section).

(e) "Radloactlve material" means any matesial or comblizillon of matarials, thith spontaneousis emits lonLeing radialion. Matarlals in whtch the est/mated speciftc activity is not greater than 0.002 mjcrocurlas por gram of matertal, and in which the radloactlolty is esentially unlformiy dlstrlbuted, are not considered to be radlosctuve materdals.

(f) "Removable radlosetlve contamInatlon" means radtoactive contaming. ton which can be readily removed is meastrable quanttiles by wiplng the contarrinated surface with an absork int miterlal. The measurable quandties shall be constdered as being not slenifieant if they do nol exceed the limits speedlied in 1173.397.

(B) "Speclal form radloactive materials" mears thoce nhich, if released from a package, mitht present some disect radiation hazard but would pre. sent little hazard due to radlotaxdel ty and listle posadbints of contamination. This may be the result of Inberent propertles of the malerial (such as metais or al. loys), or acquired characteristlos, as through encopsulation. The etllerle sor determining whether a material meets the definition of spectal form are prow scribed in $1173.398(\mathrm{~B})$.

(h) "Transport group" means any one of seven stoups into whlch normal form radlonuelldes are classined actordint to thelr radiotoxielty and thelr relative potantlal hazard io transportation, and as Iisted in 173.390 .

(1) "Trenspott Index" means the number placed on a package to designate the derree of control to be exerclsed by the cartier during transportation. The transport Index to be ansigned to a package of radloactive materjals shall be deter. milaed by elther subparagraph (1) or (2) of thils paragraph, whichever is larger. The number expressing the transport
Index shal! be rounded up to the next bighest tenth: e.8. 2.01 becomes 1.1.

(1) The highese eadjatlon dose rate. in millirem per hour at three feet frott any accessible external surface of the packase; or

(2) For Fissile Cluss II packages only. the transport jadex Dumber calculated by divlding the number " 50 " by the number of simliar packeres which nas? be transported logether (set 1273,396 ). as determined by the procedures pre. sorlbed in the regulations o! the D.S. A tomic Enercy Commisston. Title 10, Code of Federal Regulation, Part 71.

(1) "Type A packsaging" means prckaning which is designed in accordance with the general packaring requlruments of $\$ \$ 173.24$ and 173.393 , and which is adequate to prevent the loss or dispersal of the radloactlve conterils and to retain the efirclenty of tis radistion shleldins propertles if the package is stibject to the tests prescrlbed in 173.398 (b).

(k) "Iype B packaglng" means packoging which meets the standerds for Type A packaging, and, in sddition, meets the standards for hypothetical accldent conditjons of transportation as prescrlbed in / 173.398(c).

(1) "Type A quantikg" and "Type B quphtity" radioactlve msterisls means a quantity the ageregate radlouctints of which does not exceed that specteded as collows:

\begin{tabular}{|c|c|c|}
\hline 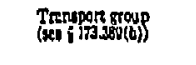 & 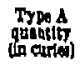 & $\begin{array}{l}\text { Typos } \\
\text { quintity } \\
\text { llo cartios) }\end{array}$ \\
\hline Wif & $\sum_{201}^{0.01}$ & $\begin{array}{r}40 \\
200 \\
200 \\
8,00 \\
60,00 \\
8, \infty 0\end{array}$ \\
\hline
\end{tabular}

1 Bucept that gor cellforalum-24t the Trpe A guturuty jimlt for epectel form to 2 curles.

(m) Containment system. Contaln. ment gistem of a radioactlve materials package meang those components of the packaging including spectal form encapsulation where used, whtch have been specified by the package destpmer as insended to retain the radionctive contents during transport, whether or not indivd. ual vessels in the packating retain their intertity of containment.

(b) Masimum normal operoting pressure Maximum normal coescting pressure means the madmum p'cssure above atmospheric gressure at mean sea level 
that would develop in the containment system in a partod of 1 jear, under the conditions of temperalure and solar radlation corresponding to entronmental conditions of transport in the absence of venting, exterasl cooling by 4h anclilary system, or operationel controls during transport.

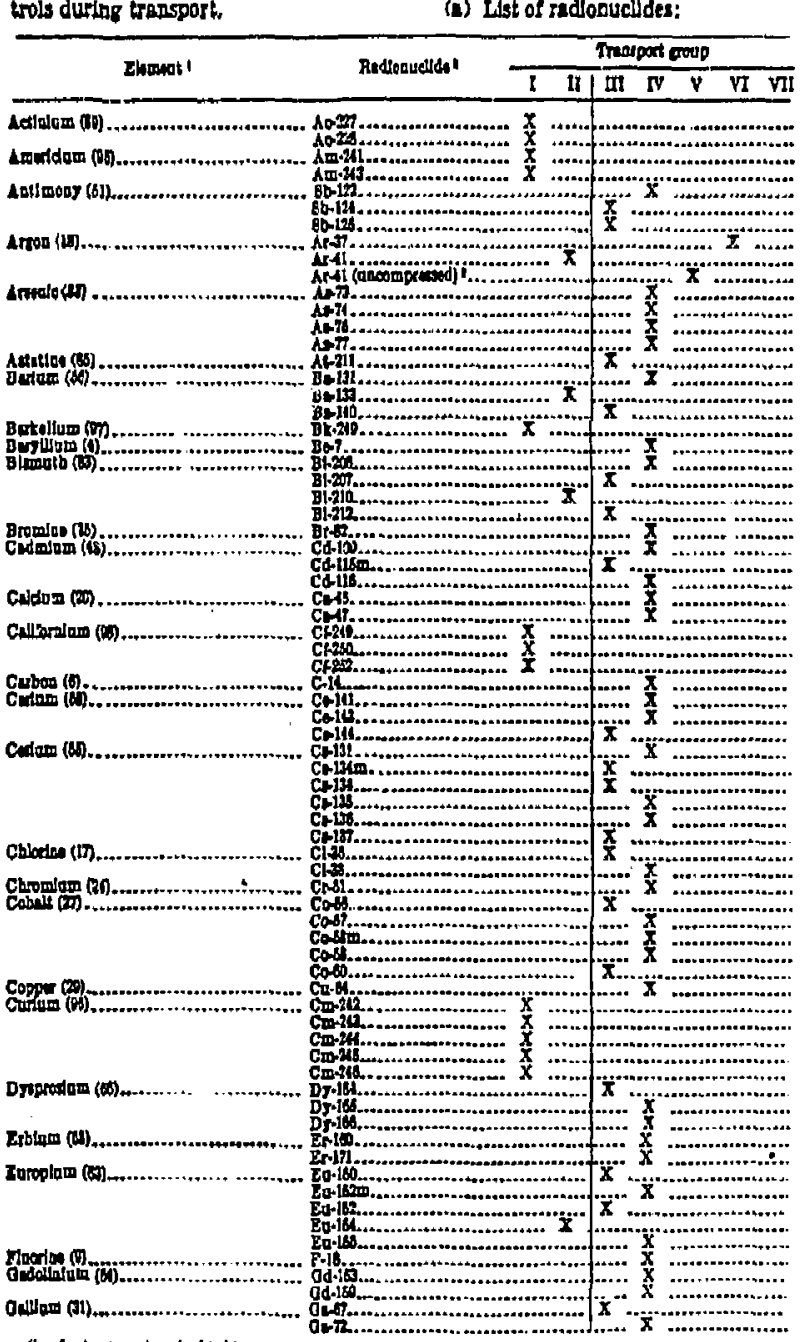

(Andt. 173-3, 33 FR. 14028, 00t. 4, 19'2; F.R. 10827, Dec. 77, 1048, as amend bF Amdt. 173-Q4, 37 PR. 14583, Juig 2L, 372 Amet. No. $173-66,37$ FR, $17970,8 \mathrm{e}$ 1972]

5173.390 Transport eroups of radio. nuelides.

(a) List of radionuclides: 


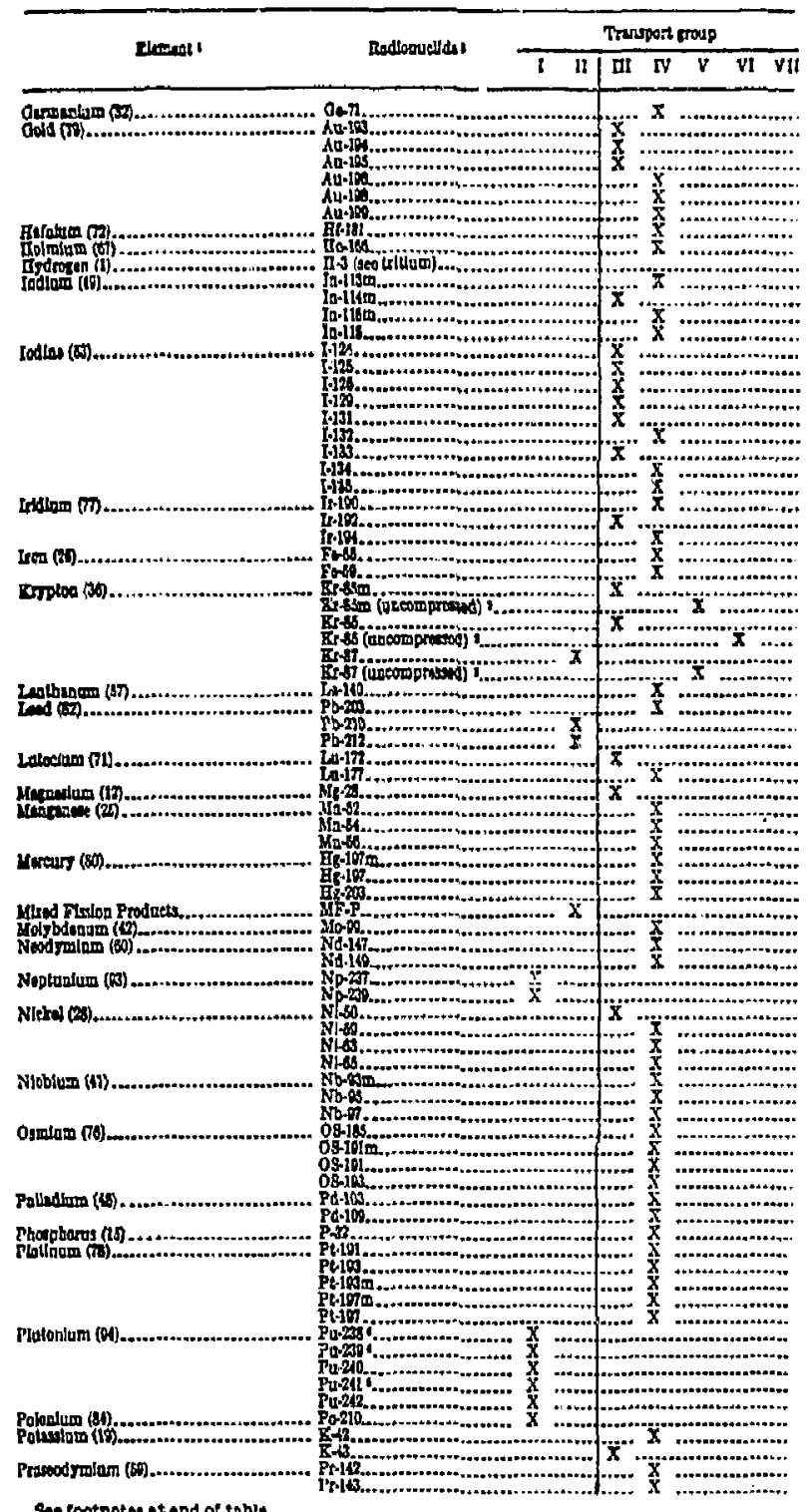

sos rootnota at end of thble. 


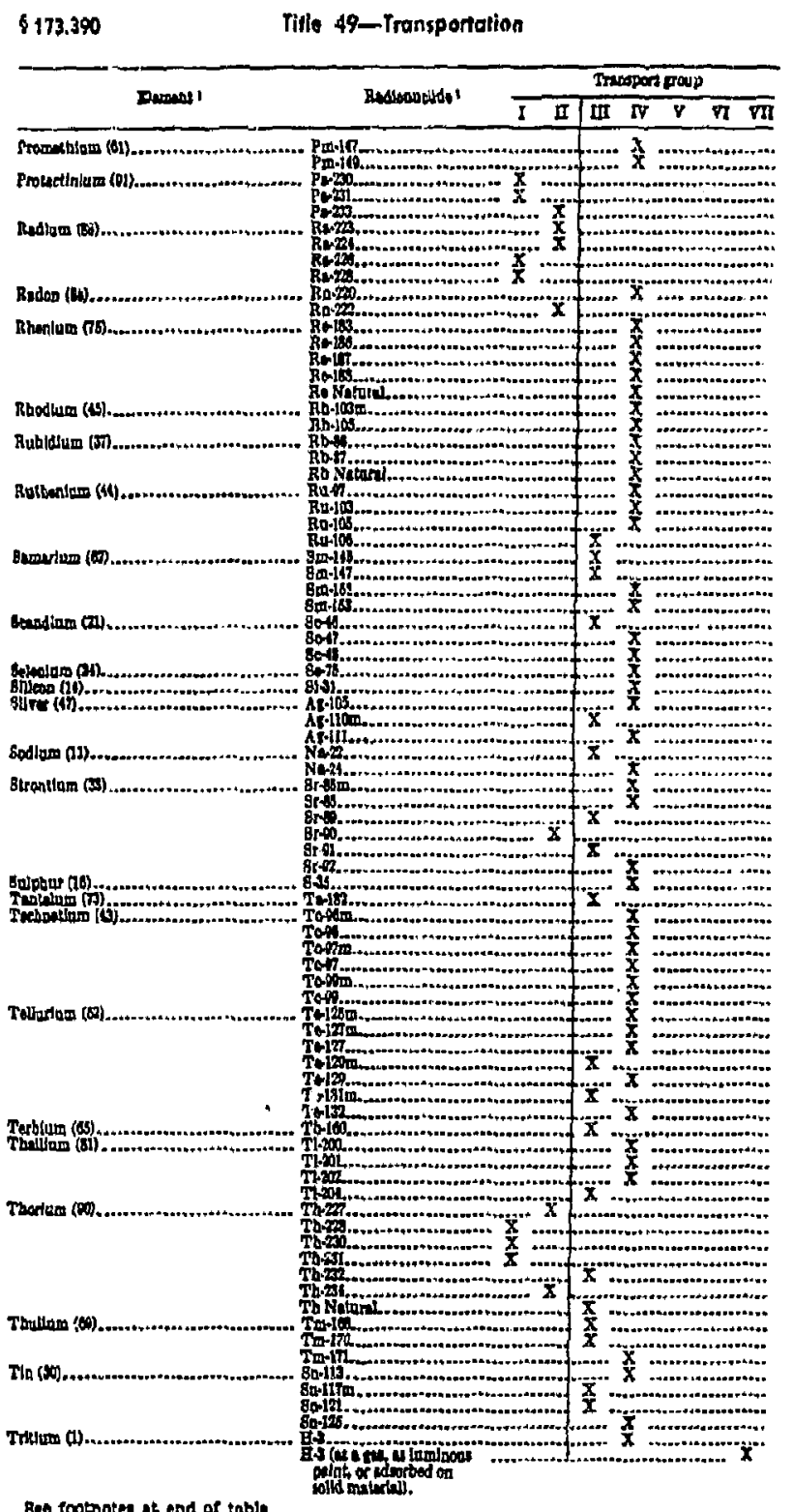




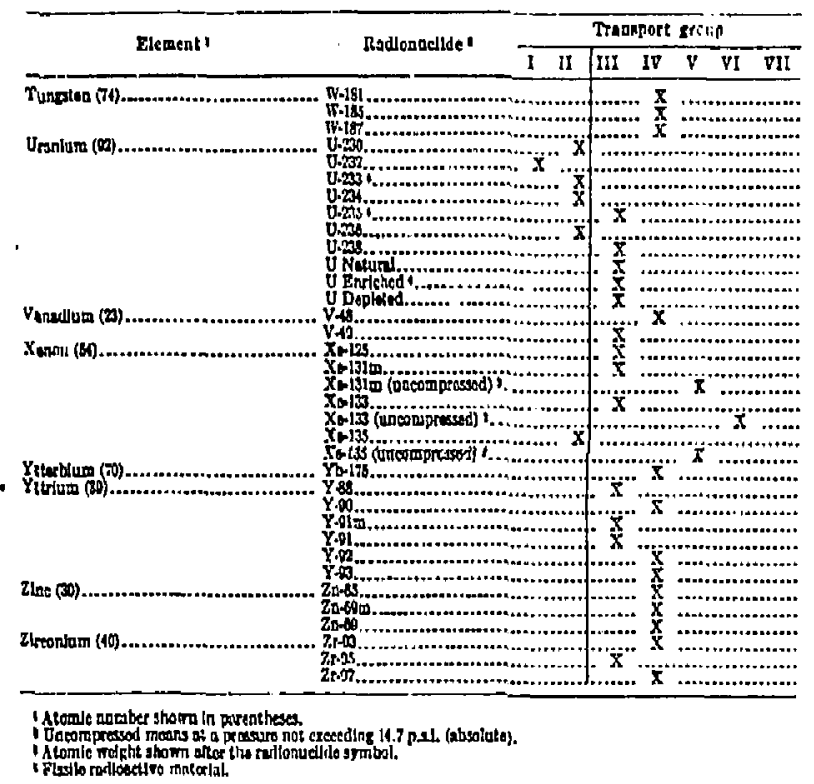

(b) Ang radionucilde not listed in the above table shall be assigned to one of the grougs in accordance with the following table:

\begin{tabular}{c} 
Redorcelldo \\
\cline { 2 - 4 } \\
\hline
\end{tabular}

Alamie anmber Orouptr. Oroop II... Omoup H1. cod ore.

Norm 1: Mo unlitted redlonuclides abel be adgeed to Groups IV, V, $\mathrm{VI}$, or Vtt.

(c) For mixtures of radlonuclides the lollowing shell appls:

(1) If the identity and respective sctivity of etch radlonucllde ate known, the permissible activlty of each radioatuclide ahail be such that the stem, for al] croups present, of the ratio between the lotal activity for each group to the per. misslible activity for each group wils not be grcater than unity.

(2) If the groups of the rathonvelides are knowa but the amount in each group cannot be reasonably determined, the mixture shall be assigned to the most restrlative group present.
(3) If the !dentity of all or some of the radlonucildes cannot be teasonably determined, each of those unidentifled redlonvelides shall be considered as belonglas to the most restrictlye 8roup which cannot be positsvely excluded.

(4) Mixtures consisting of a single radioactive decay chain where the radioauclldes are in the naturally occurring proportlons shell be considered as consisting of a single radlonuclide. The group and actlyty shall be the: of the Atst nember present in the chain, except if a cadlonuclide " $x$ " has a halt-Ufe longer than that of that first member and sn acturty grester than that of any other member including the first at any time during transportation; in that case, the transport group of the nutulde " $x$ " and the activlty of the mixture shall be the maximuin activity of that nuclice " $\mathrm{x}$ " durheg transportation.

|Amdt. 173-3, 33 F.9. 14023, Oet, 4, 1908) 
ALFENDIX C

PAPER BY

DR. W. A. RODGER 


\title{
Critical Evaluation of the Limit of Transuranic Contamination of Low Leve! Waste
}

by

\author{
Walton A Rodger \\ Nuclear Safety Associates \\ Bethesda, Maryland
}

Throughout this afternoon's session we have heard details of the kinds and quantities of wastes which will be produced at reprocessing plants. It is the purpose of this paper to consider the effect upon these reprocessing wastes, and the potential effect upon reactor and other fuel cycle wastes, of the use of a transuranic linit of 10 nanocuries/grar.

The "limit" of 10 nanocuries/gram has not as yet been set finally and fully in Regulatory concrete. But it is close enough to being set that if vigorous and resolute troweling does not very soon take place, the surface of the walkway will forever be gouged and blemished.

Ien nanocuries/gram is a classic example of regulation by bureaucratic fiat, without consideration of what level is really required, without benefit of environmental impact statement, without benefit of cost-benefit studies-and certainly without benefit of clergy. It is a level selected arbitrarily by the AEC (ERDA Division) as guidance to its contractors for segregation of waste for possible (emphasis mine) later transfer to a National Repository. It is a level which has been suggested by AEC (NRC Division) as a footnote to a proposed rule making. It is a level which has been enthusiastically embracad by over-zealous State Regulatory types to the point it has essentially become law by default. It is a crying shame!

In order to properly determine a limit for transuranic contamination, we must first define what it is we are trying to accomplish. We must establish who it is we are trying to protect and from what. Six years ago in a paper given at Bal Harbour this author suggested that our Regulators had not answered these two questions, (1) They still haven't. There are only two plausible answers to these questions. He are trying either:

1) to protect the air and water supply of the general public from contamination at levels approaching MPC, in either the immediate or longterm future, or

2) to protect any individual at any time in the future from stumbling onto the material and either eating or rore likely breathing the material in sufficient quantity to injure himself. 
The first of these goals is a sine gua non for any arceptajle waste disposal systern. It is highly unlikely that the second can be guaranteed no matter what we do, and it is highly questionable that it should be done, even if it could be done. Let us first consider reprocessing wastes in light of these two goals.

\section{High Level Wastes}

Earlier papers in this session have shown that solidlfied high level waste, the only reprocessing waste wich has received any in-depth consideration, represents only $3 \%$ of the volume of wastes produced by a reprocessor. This waste is the only self-heating waste produced. It contalins essentially all of the fission products, americium and curium from the spent fuel; it also contains 1 to 2 percent of the plutonium and up to 1 percent of the uranium. It has already beed edicted that this waste nust go to the National Repository - whether because of its fission product content or of its transuranic content is not completely clear.

Figure 1 illustrates the character of the high level waste as a potential contaminator of drinking water. (It is presumed that in any event waste would be buried sufficiently deep that the possibility of uir contaminaticn is eliminated.) The left-hand ordinate of Figure 1 gives the volume of water required to dilute the waste products from a tonse of fuel to drinking water tolerance, a value which I have called the hazard index. The right hand ordinate gives the length of time a small creek $\left(10^{7} \mathrm{cc} / \mathrm{sec}=350 \mathrm{CFS}\right)$ would have to run to produce the amount of water called for by the hazard index. The abscissa is time of decay. The backup calculations for Figure 1 are given in Table 1. A number of interesting observations can be drawn from Figure 1.

1) When the waste is shipped to the repository (after 10 years onsite storage) 28-year Sr-90 accounts for $99 \%$ of the total hazard potential. It continues to be greater than half of the total for 300 years.

2) At the end of 300 years the hazard potential has dropped by a factor of just about 1000 . At that time the flow of our small $\left(10^{7} \mathrm{cc} / \mathrm{sec}\right)$ creek would dilute the waste from a tonne of fuel to drinking water tolerance in less than a year.

3) From 300 to 1000 years the hazard index is dominated by 458-year Am-241. At the end of 1000 years the total hazard index has dropped by a factor of about 5000 and it is then no greater than that of the natural ore which produced that tonne of fuel in the first place. Our small stream would dilute the entire tonne to drinking water tolerance in about 100 days. 
Critical Evaliation

page 3
NLCLEIR S.LET": ASSOCITIES $8 / 28 / 75$

i) From then on decay proceeds more slowly. From 1000 to 10,000 years the hazard index is dominated by 8000-year An-243. From 10,000 to 50,000 years 24,300 -year Pu-239 dominates. This is the only period of time during which any plutonium isotope is the dominast factor. After 50,000 years the hazard index has been reduced by a factor of 70,000 and our small strean would require but three days to dilute the remaining activity to drinking water tolerance.

5) From 50,000 to 2,000,000 years the dominant activity is Ra-225not a transuranic. After 2,000,000 years the hazard index has been reduced by a factor of 5,000,000. Our small stream would need one hour to dilute the remaining waste products to drinking water tolerance. The waste still exceeds the "magic" 10 nanocuries/gran by a factor of about 100!

6) After 2,000,000 years and for the next $8,000,000$ years a transuranic, 2.2 million-year $\mathrm{Np}-237$, takes over as the doninant isotope. During this period, after a total of 4,000,000 years have elapsed, the waste reaches the hazard index of pure U-233 (no U-235 and no daughter products; remember too that $\mathrm{U}-233$ is three to 90 times as toxic as a heavy metal than it is as a radiological hazard). At this point tie hazard index has been reduced by a factor of 20 million and our small stream fould dilute the remaining waste products to drinking water tolerance in less than 15 minutes. Yet the waste is still about 30 times the "magic" number!

7) After $10^{7}$ years the waste becomes a uranium waste with the 235 , 235 , and 238 isotopes all contributing. After about 40 gillion years the waste finally reaches 10 ranocuries/gram, Bingo! At that point the small strean will dilute the 10 nanocuries/gram to drinking water tolerance in a few seconds. Mirabile Dictu!

From the above I draw the following conclusions:

1) In order to meet the first, and most important criterion-the protection of public water supplies-we need design on!y for the $\$$ Im90 content.

2) By the time ary transuranic component becomes importent the magnitude of the problem has been reduced by a factor of 1000 .

3) I can conceive of no process, geologic or galactic, which would thereafter convert a problen which has been under control for a millenium to one which is out of control.

4) Therefore at the end of 1000 years the problem has been solved.

5) It follows that there is no need to impose any transuranic limit on high level waste insofar as protecting public water supplies, nor or at any time in the future, is concerned.

6) We shall consider the "stumbler tumber" in connection with other reprocessing wastes. 


\section{Spent Fuel Elements}

At the present time there is no assurance that spent fuel will ever be reprocessed. And there will te no reprocessing until a favorable "GESMO" decision has been made. If recycle of plutonium is not permitted, nuclear energy is not going to go away, as is hoped by many opponents of nuclear energy; instead spent fuel elements will be buried rather than weste. It is of interest, therefore, to note how spent fuel elements compare to reprucessing wastes. Figure 2 is similar to Figure 1 except that the "wastes" discarded are the spent fuel elements themselves. Data backing up Figure 2 are shown in Table 2.

From Figure 2 and Table 2 the following observations can be draw.l.

1) Spent fuel elements, while they represent a somewhat greater hazard than reprocessing wastes, differ from them only in degree, not in kind.

2) Again for the first 200 years the hazard is dominated by Sr-90. At the time the fue! elements would be buried Sr-90 would account for more than $99 \%$ of the hazard potential.

3) In this case it will take 10,000 years to reduce the hazard potential to that of the ore from which the tonne of fuel origizally came (vice 1000 years for reprocessing waste).

4) Plutonium isotopes dominate the problem only during the perlod from 1000 to 50,000 years. In this period the hazard potential is 2.5 to 4 orders of magnitude less than it was originally when dominated by Sr-90.

5) Fron 50,000 to two million years $\mathrm{Ra}-226$ is the dominant activity; from two million to five million years it is $\mathrm{Np}-237$; from five million to ten aillion years it is $\mathrm{Np}-237$ plus U-236; from ten to 100 siilion years it is the three uranium isotopes; thereafter it is U-238.

6) It takes about a quarter of a jullion years to reach the hazard potential of $U$-233. For al! practical purposes fuel elements would never reach 10 nanocuries/gram.

The conclusions drawn in respect to high level waste hold also for spent fuel elements. The comparison of spent fuel with wastes is more easily seen on Figure 3. The integrated area under the spent fuel curve is approximately three times that under the waste curve.

\section{Leached Hulls}

He have seen that there is four times as much volume of leached hulls as there is of solidified high level waste. At the present time hulls 
would be charged for, and treated as, high level waste-so the cost of disposal of hulls will he several times the cost of disposing of high level raste. This is, of course, an absurdity and presurably some nore logical handling of hulls will be developed. By why should hulls go to the Repository in the Eirst place? Table 3 and Figure 4 stow the characteristics of hulls as waste as a function of time. These exhibits were prepared deliberately using much too high inses to the hulls, A loss of $0.5 \%$ of uranium, plutonium, Eission products, and anerictum and curium to the hulls has been assumed, This should represent the absolute upper limit of losses to hulls. The average loss is about $20 \%$ or less of this. Even with this overstatement of loss it can be seen that:

1) As we have seen before the waste is initially dominated by Sr-90 and it continues to be so for 200 years.

2) After just 100 years the hazard potential of the hulls has fallen to that of the ore which prodused the fuel in the first place.

3) By the time the first transuranic isotope becomes importent (An-241 after about 300 years) the hazard index has dropped by a factor of over 200 , and it is more than an order of magnitude less than thit of tha initial ore.

4) On Figure 4 the I-129 contribution has been shown. I-129 is nevel: present in concentrations greater than 1 nanocurie/gram. Yet its hacard index dominates the total from 5 million years to 100 million years. This well illustrates the fact that any concentration limit innores the differences in radiological hazard of the various constituents.

Now let us set up a more logical scenatio in which hulls are not sent to the Repository at a1l, but rather are kept at the producing site. I have found that my friends at NFS and AGWS are both sensitive to calculations basej on their sites. Therefore I will base the following calculations on an hypoihetical site with the following characteristics:

Plant Owner:

Capacity:

Location:

Plant Discharges and Site Drainage to:
AGOTHS Corporation

1000 tonnes/year

West Barnsmell, New Carolina

Lower Three Cat Creek

$$
\text { (average flow } 10^{3} \mathrm{cc} / \mathrm{sec}=350 \mathrm{CES} \text { ) }
$$

Hulls buried in soil with the following characteristics:

$\begin{array}{ll}\text { Porusity } & 0.15 \\ \text { Den-ity } & 2 \mathrm{~g} / \mathrm{cc} \\ \begin{array}{c}\text { Distance to } \\ \text { nearest surface water }\end{array} & 3000 \mathrm{~cm} \\ \begin{array}{c}\text { Rate of water movement } \\ \text { in soil }\end{array} & 0.1 \mathrm{~cm} / \mathrm{daj}\end{array}$


Critical Evaluation

page 6
NLCLEAR SAEETY ASSOCI UT\% $B / 28 / 75$

Ion exrhange constants for soil:

$\begin{array}{lc}C o-60 & 2500 \text { mej/gramsolic } \\ \text { Sr }-90 & 50 \\ \mathrm{I}-129 & 25 \\ \mathrm{Cs}-137 & 2500 \\ \mathrm{Pu}, \mathrm{Ar}, \mathrm{Cm} & 2500\end{array}$

Now I an going to assume that hulls from 30 years of operation are buried in this soil and that all of these nulls are at the overly conservative concentration used previously, i e $0.5 \%$ loss of all components to hulls. And I an going to anaiyze the possibility that any activizy could present itself to Lower Three Cat Creek at concertrations approaching the concentrations permitted by Appendix $B$ of $10 \mathrm{CFR} 20$.

Numerous mechenisms are operative to provide a defense in depth against abrogation of the burial grouni's conteinment of rajioactivity. These mechanisms include:

Retention of the radioactivity in and on tire waste itself.

Retention of the radioactivity within the wirial trench soil.

Setention of the radioectivity on the soil tetween the trench and any point of emergence.

Decay of radioactivity during travel time from the trench to the nearest watercourse.

Dilution of emergent activity in Lower Three Cat Creer.

A discussion of each of these mechanisms follows.

Mechanism No. 1-Retention in Hulls. Nore than $95 \%$ of the radioactivity associated with the leached hulls is induced radioactivity, primarily Co-60, and is an ittegral part of tin: metal itself; therefore, in order for this radioactivity to escape, the metal itself must dissolve. The remainder of the radioactivity associated witl hulls is fission productiand trarsuranic species in the form of refractory oxides. All of this radioactivity which remains with the hulls failed to be remover from the hulls during several hours of vigorous boiling in mitric acid and during subsequent washing; consequently, ground water should rerove these radioactivities only very slowly, if at all.

To ay knowledge there have been no direct measurements made of the rate of reava! of activity from buried leached hulls partly because not 
many have been buried as yet and partly because the removal rate is so low it is essentially not measurable. It is inconceivable that the removal rate from leached hulis could be within several orders of magnitude of that for mixed trash; however, for this analysis an annual renoval fraction from the hul Is was assumed to be only one factor of ten below that experienced for general trash burial grounds, i e $10^{-7}$ escape from hulls per year (see Mechanism 非),

Mechanism No. 2-Retention in the Burial Hole. The escape rate of radioactivity from buried weste his been estimated based upon experience in the operation of the commercial burial ground at West Valley, Ny. In 1970, a burial trench was filled during just about one year's operation. When completed it contained about 150,000 cubic feet of buried waste (300,000 cubic feet of trench volume and the estimatei gross radioactivity was 40,000 to 45,000 curies. When the trenches are dug they are sloped to one end and filling is started at the other end. During filling, rain and snow collect in the open trench and thts water is kept pumped out into a monitoring lagoon. Any leaching operation is greatest at the initizl point: and tails off with time; therefore, the amount of radioactivity getting into this rain water during the filling period should be a reasonably good measure of the maximum escape rate which vould ever be expected. During the approximately one year the trench was being filled about $10^{6}$ gallons of liquid were pumped frum the trench into the waste buriat lagoon where they were monitored before discard. The activities measured in this water ranged from $10^{-6}$ to $10^{-4} \mu \mathrm{c} / \mathrm{cc}$ and averaged ajout $10^{-5} \mathrm{\mu l} / \mathrm{cc}$. At $10^{-5} \mu \mathrm{c} / \mathrm{cc}$ the million gallons accounted fnr a total of $40 \times 10^{-3} C_{i}$ of radioactivity of the estimeted total content of 40,000 curies. So the approximate annual escape fraction was $10^{-6}$.

Because the fractional escape coefficients for trash burial inelude factors for both the retention on the waste itself and for the retention within the trench by precipitation and natural ion exchange, no additional retentic: of the leached huil activity is assumed in this analysis for the ion exchange within the trench itself. However, since the retention of radloactivity an and in the hulls obviously sill be wuch greater than that for mixad trash, the use of an escape rate from the hull trench of $10^{-7}$ fraction/year (only one factor of 10 lower than that demonstrated for trash burial) is believed highly conservative and the expected release is several orders of nagnitude lower.

Mechenism No. 3-Retention of Radioectivity within soil neer the trench. If radioactivity were to move out frnm the initial burial trench, it would be confronted laterally by $3000 \mathrm{~cm}$ (100 feet) or soil. Experience with the trash burial trenches has shown that it is not possible to find radioactivity 
in the surrounding soil more than a few feet from the trenches, thereby indicating that any radioactivity whicl does escape the trench is being reabsorbed on the surrounding soil.

The natural ion exchange capacity of the soil through which any activity which escaped the initial trench would have to move before reaching surface water is so vast that no radioactivity, with the exception of tritium (when present) and very long-lived isotopes, would be able to move very far trom the trench before $j$ t had decayed to insignificance. The effectrof the natural ion exchange capacity of the soll is to greatly slow cown the rate of movemeni of the radioactivity through the soil in relation to the movement of ground iater through the same soil.

To characterize this slowing down a soil-water equilibrium model was set up, equations developed, and solutions to the equations were accomplished with a relatively simple computer program, INTERLOC. For all values of the problem parameters of practical iuterest the solution can be approximated very elosely as follows:

$$
\begin{aligned}
& F_{i}=\frac{1}{(2 \pi n) k k_{D i}} \\
& T_{i}=\frac{U K_{D i}{ }^{R}}{W} \\
& n=\frac{D}{\omega t e} \\
& R=\frac{(1-P)_{0}}{P}
\end{aligned}
$$

where:

$\bar{r}=$ maximum fraction of initially released actitity which will ever appear at point of discharge (decay neglected), dimensionless.

$I=$ time at which the maximum fraction, $F$, will be seen at the discharge point, days.

$n=a$ dineasionless parameter which in effect charcterizes the number of "equilibirum stages" of ion exchange evailable during transit.

$K_{D}=$ equilihrium constant for ion exchange, $\frac{\text { meq/gram solid }}{\mathrm{meq} / \mathrm{cc} \text { liq!1id }}$

$P=$ porosity of the soil, cc liquid/cc

$\rho=$ density of soil perticles, g/cc

$\mathrm{D}=$ distance through which water and radioactivity must travel to reach discharge point, $\mathrm{cm}$ 
$W=$ rate of travel of water, $\mathrm{cm} /$ day

$t_{e}=$ time for ion exchange equilibrium to be established, day

$\mathrm{R}=$ ratio of solid to liquid in soil, gram solid/cc liquid

$i=$ identification of specific nuclide

Equilibrium is reached very quickly-in less than an hour. For conservatism, I have used in these calculations a va ue of 1 day for $t$. The use of 1 hr vice 1 day for $t e$ would produce a value of $\mathrm{F}$ a factót of five lower.)

Based $n$ the assumptions outlined above, the following ma:imum fractions released to sulface streans are:

\begin{tabular}{|c|c|c|c|}
\hline Nuclide & $\pi_{D}$ & $T_{\text {, days }}$ & $\begin{array}{l}\text { Meximum Fraction of Released } \\
\text { Activity at Release Point }\end{array}$ \\
\hline $\mathrm{Co}-\mathbf{1 0}$ & 2500 & $8.5 E+0 B$ & $B E-0 B$ \\
\hline $\mathrm{Sr}-90$ & 50 & $1.7 E+07$ & $4 E-C 5$ \\
\hline$I-129$ & 25 & 8. $5 E+05$ & $B E-06$ \\
\hline Cs- 137 & 2500 & $3.5 E+08$ & $8 \mathrm{E}-08$ \\
\hline $\mathrm{Pu}-238$ & 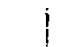 & & $\cdot$ \\
\hline $\mathrm{P}_{11-239}$ & & & \\
\hline $\mathrm{Pu}-240$ & & & \\
\hline $\mathrm{Pu}-241$ & & & \\
\hline $\mathrm{Pu}-242$ & & & \\
\hline$A m-241$ & & & \\
\hline$A m-243$ & & & \\
\hline $\mathrm{C}_{\mathrm{n}}-242$ & & & - \\
\hline $\mathrm{Cm}-244$ & $\downarrow$ & $\downarrow$ & $v$ \\
\hline
\end{tabular}

The values of $F$ represent the fraction of the initiaily released activity which would be seen at the time of maximum discharge concentration if there were no decay during transit. This fruction results simply from the spreading out of the band of released activity tirough the soil and the holdup of a large fraction of the activity on the solid particles through wich the liquid flows. 
Mechanisn No. 4-Decay during Travel. As indicated above, the effect of the natural ion exchange capacity of the soil is to produce a time of travel for the radioactivity much longer than that for the ground water. The time of appeararice of the maximum of the "astivity wave" is incependent of the assumed equilibrium tim $(1 \mathrm{a}$, it is independent of $n$ ) bat it is a function of $\mathrm{k}_{\mathrm{D}}$. During the time of travel radioactive decay will of course take place such that the fraction of the indtialiy released activity remaning at the time of appearance of the "wave crest" will be:

$$
\text { Fraction remaining }=e^{-\lambda_{i} I_{i}}
$$

For the postulated ielease this amounts to:

\begin{tabular}{|c|c|c|c|c|}
\hline Isotope & $\begin{array}{l}\text { Half Life } \\
\text { years }\end{array}$ & $\begin{array}{c}\lambda \\
\operatorname{dev}^{-1} \\
\end{array}$ & $\begin{array}{c}\mathrm{T} \\
\text { days }\end{array}$ & $e^{-\lambda_{i} T_{i}}$ \\
\hline $\mathrm{Co}-60$ & 5.2 & $3.7 E-04$ & $8.5 \bar{E}+08$ & $4 \mathrm{E}-100$ \\
\hline $31-90$ & .28 & $6.8 E-05$ & $1.7 \mathrm{E}+07$ & $\angle E-100$ \\
\hline I- 129 & $1.6 E+07$ & $1,2 \mathrm{E}-10$ & $8.5 E+05$ & 0.998 \\
\hline$C s-137$ & 30 & $6.3 \mathrm{E}-05$ & $8.5 E+08$ & $\therefore E-100$ \\
\hline Pu -238 & 86 & $2.2 E-05$ & 7 & $\angle \mathrm{E}-100$ \\
\hline$P L-: 39$ & $2.4 E+04$ & $7.8 \mathrm{E}-08$ & & $1.6 \mathrm{E}-29$ \\
\hline$P u-240$ & $6.6 \mathrm{E}+03$ & $2.9 \mathrm{E},-\mathrm{O} 7$ & & $<\mathrm{E}-100$ \\
\hline Pu-2.41 & 13 & $1.5 \mathrm{E}-04$ & & $\angle E-10 i$ \\
\hline $\mathrm{Bu}-242$ & $3.8 \mathrm{E}+05$ & $5.0 \mathrm{E}-09$ & & $1.4 \overline{\mathrm{z}}-02$ \\
\hline$A m-241$ & $4.6 \mathrm{E}+02$ & 4. $1 \mathrm{E}-06$ & & $\angle E+100$ \\
\hline$A m-243$ & $7.8 \mathrm{E}+03$ & $2.4 Z-07$ & & $2.5 \mathrm{E}-89$ \\
\hline $\mathrm{Cm}-242$ & 0.5 & $4.3 \mathrm{E}-03$ & & $\angle \mathrm{E}-100$ \\
\hline Can-244 & 17.5 & $1.1 E-04$ & $V$ & $\angle E-100$ \\
\hline
\end{tabular}


Mechanism No. 5--Dilution in Watercourse. We have assumed that the small watercourse into which the burial area drains has an average flow of about $1 E 07 \mathrm{cc} / \mathrm{sec}(8.6 \mathrm{E} 1 \mathrm{l} /$ day--3.1E14 cc/year) and that this amount of water is available to dilute whatever activity finally reaches the stream. A sumnary of the calculations outlined above is given in Table 4. It can be seen from that table that the concentration of each isotope is less than $\mathrm{E}-100 \mathrm{Hc} / \mathrm{ml}$ with the exception of I-129, Pu-239, and $\mathrm{Pu}-242$. The highest value is that for I-129, $1.5 \mathrm{E}-20 / \mathrm{kc} / \mathrm{cc}$. This is an unmeasureable, insignificant value 12 orders of magnitude below MPC. Pu.242 is of the same order of insignificance as I-129. Pu-239 is another $2 j$ orders of magnitude lawer. The rest are all less than E-100. These extremely low concentrations well illustrate the mathematical trap we fabricate when using negative exponents - there is no zero. One is tempted to say (as does my HP-35) that E-100 is zero, and there is no release,

Thus our first and most important goal, the protection of the public water supplies, can be quite easily met by many well selected sites. The plutonium problem has been blowa out of all proportion. To meet this goal we need have no transuranic concentration limit at all. Rather we need to establish total inventory limits based on a particular site's capability for containment of activity.

That leaves us then with the second problem, the 25 th century stumbler. If we are to go to great lengths to put these wastes in geologically stable formations, the justification has to be that we are trying to reduce the "stumble quotient", the required expenditures cannot be justified on the basis of protecting water supplies.

So how is our stumbler going to be exposed. First he has to dig into the waste. Then he has either to eat it or to breath it. The latter seems the more likely. Consider the effect upon a stumbler digging into the overly conservative concentration of hulls we have been considering. At the end of thirty years the total inventory of buried hulls would contain about 7E05 curies of plutonium alpha activity in about 3E04 cubic meters. At a density of 2 grams/cc this would be an effertive plutonium concentration of about 10,000 nanocuries per gram. At an average specific activity of 0.33 curie/gram, this is equivalent to $6.5807 \mathrm{Hgrams} / \mathrm{m}$. or $33 \mathrm{Hgrams} / \mathrm{gram}$. Now suppose our "stumbler" were to dig out $1 \mathrm{~m}$ of this waste in 1 hour, stirring up dust the while. reasonable dust level for such as operation might be about $1000 \mu g r a n s / \mathrm{m}^{3}$ of air and he would be expected to breathe about $1 \mathrm{~m}$ of air in one hour. Therefore in an hour of vigorous digging into this waste he would have taken into his body $0.001 \times 33$ or 0.033 Hgram of plutonium. Cohen has calculated that the required intake of reactor-produced plutonium to produce a cancer (after 
15 to 45 years $>$ is about:
Inhalation
260 igrams
Ingestion
2.3E06 Hgrams.

Thus in bis one hour of digging the stumbler would have taker in $\frac{0.033}{260}$ or about $10^{-4}$ of the amounc necassary to acquire a cancer-producing body burden. If he dug up about 8 third of the total buried waste (it would take him about three years at 8 hours/day), he would have about achieved the intake necessary to have a $50 / 50$ chance of acquiring a cancer in 15 to 45 years. If the stumbling accurred more than 200 years after burial (and it better since the $\mathrm{Sr}-90$ would have gotten him long before the plutonium would do him in) then the toxicity of the plutonium would be about four times less due to the decay of the Pu-238 and he wnild have to dig up the whole waste body (over about twelve years) to reac.. $260 \mathrm{Hgrams}$ intake.

Of course he could eat the waste. If he did this he would have to eat $\underline{2.3 E 06}$ or 70,000 grans $(150 \mathrm{lb})$ of the waste. 33

It is passible, but does not seen likely, that one of these events might occur. But in any event we are dealing with an hypothetical individual -not the general public. Furthermore no matter what we do with the waste, I suggest you cannot guarantee that for all time no one will ever stumble on that waste, at which point you must consider the same scenario. In fact I believe that burying waste in salt, an article of commerce and food, almost guarantees that some day someone will dig into it.

Remember also this example is based upon a hulls containing the highest conceivable concentration of transuranics. (Even high lavel waste would contain no more.)

Consider the same scenario at the proposed 10 nenocurie/gram level. Now our stumbler would have dig up the entire body of waste (over ten years) and he would still have taken in only 0.003 of the plutonium required for a $50 / 50$ prohability of latest cancer. Alternatively he would have to eat $150,000 \mathrm{lb}$ of the 10 -nanocurie waste.

So on both counts the 10 nanocurie-gram limit is too low. For protection of water supplies no limit at all is necessary. To protect the stumbler, if that even can be done at all, the value is vastly out of line, 
Now what additional costs are imposed by the use of a limit on transuranics of 10 nanocuriesigram. First of all the limit will require that the hulls, which we have shown could be safely buried on the West Barnsmell site, will have to go to the Repository. And at, present they would be chargec for as high level waste. A recent study suggests that the cost of shipping the hulls to the Repository plus their handling at that site will be between $\$ 20$ and $\$ 30$ per $\mathrm{kg}$ of fuel processed. Thus the additional cost to each reactor will be about $\$ 600,000-900,000 / y e a r$. For the 150-odd reactors now in operation or under construction this amounts to an annual bill of $\$ 90,000,000$ to $\$ 135,000,000$.

The 10-nanocurie limit will also dictate that most, if not ell, of the $180,000 \mathrm{cu} \mathrm{ft} /$ year of other waste from the reprocessing plant would have to go to the Repository. Since all of these wastes would have transuranic contents well below that of the super hulls I have used for illustrative purposis in this paper, all of them could be safely buried either on the producing site or in one of the commercial burial grounds. The cost penalty for sending them to the Repository, vis-a-vis a commercial burial ground, will be not less than $\$ 25 / \mathrm{cu} f \mathrm{ft}$. Thus the penalty from a single 1500 -tonne reprocessing plant will be $\$ 4,500,000 /$ year. Such a reprocessing plant can service about 50 reactors so the annual cost for the 150 reactots already in being or under construction is between 10 and 15 million dollers per year.

Finally there is the trash from the reactors themselves to consider. At 10 nanocuries/gratin there is no way in which a reactor operator can prove that he meets this limit. It is therafore entirely possible that this reactor waste also must go to the Repository. If this were to happen an additional cost to the consumer of from $\$ 35,000,000$ to $\$ 45,000,000 /$ year would result. Thus the total annual tribute to be laid on the altar of 10 nanocuries/gram ranges from $\$ 135,000,000 /$ year to $\$ 200,000,000 /$ year.

\section{Benefit}

Now $\$ 200,000,000 /$ yeer while it is a lot of money, it is not a dis. qualifying amount of money. So if we really got atrything for the money, we could afford to pay it. The question is, what are we getting for that $\$ 200,000,000$ ?

First lets consider what we are not gettirg for the money. We are not getting anything in the way of increased protection of the public air and water supplies for the immediate (next millenium) or long-term (forever) future. In any event the possibility of indiscriminate 
contamination of water or air has been taken care of. The total justification for the expenditure of this $\$ 200,000,000 /$ year, 5 billion dollars for the rest of this century ( 1975 dol Lars), must be besed on the presumed additional protection of inadveitent stumblers into this waste in future millenia.

To justify this expenditute on a cost-benefit basis we would have to conclude that we had prevented 10,000 stumblers from dying. Personally I find it hard to believe that transferring waste from an inedible "silty till", for instance, into edible salt will do that. Nar do I see that a culture (ours) which is sytematicaliy raping the limited fossil fuel reserves of our planet and thus secting up vast numbers of future "heal th effects" should be able to soothe its conscience by pretending that as a by-product of reducing that rape (by the rational use of nuclear energy) we have protected a few stumblers over the next several million years.

Because the calculation of the "benefit" side of this equation is fraught with jmponderables and subjective judgwents, the range of answers obtained is likely to be wide. The fact that it is not easy to do does not justify not doing it. And our Regulators have no business putring forth this limit-or any other limit for that mater-without first making as careful a cost benefit analysis as practicable. There is no other way to determine what is as low as reasonably achievable.

So I have the following proposals to make in regard to the setting of limits for transuranics in waste.

1) Apply the principle of BTTODB-back to the old drafting board. Before IRC issues its next proposed rule for comment the problem should be restudied and the necessary environmental statement and as low as reasonably achievable analys is made.

2) I recogrifie that 10 nanocuries/gram has becone ingrained in a lot of ainds and will probably be hard to change. So I propose simply that it be redetined- properly this time. Ten nanocuries/gtam is not a proper dividing point between on-site or commercial burial and the National Repository; it is, however, a pruper linit to apply below which a waste could be put on the city dump or used in one's back yerd as mitlch for the tomatoes. In short it is the limit of complete innocuousness, and that is what. it should be used for.

3) A limit should be established for deciding between on-site (or comaercial) burial and the Repository. There should be two aspects to that limit. One should be a total site inventory limit. This would be 
site dependent and would be based on the capability of the site to protect the public water supplies in the area surrounding that site. The second aspect would be a concentration linit which would be based on reasonable expectations of how a stumbler might eat or breathe the waste and upon recognition of the fact that this limit is not needed for protection of the general public-but rather for the protection of a very limited number of hypothetical individuals and as such does not deserve the application of the usual superimpositions of over-conservative assumptions piled upon one another serially so as produce an absurd result.

The new limit should be determined on the basis of realistic assumptions, as outlined herein. The result should be a far cry from 10 nanocuries/gram. This discussion suggests that it should be higher by several orders of magnitude. Such a limit would provide eritipeiy adequate protection for distant archeologists and no limit on transuranics is needed to provide protection for public water supplies.

\section{References}

1 A Rodger, "Effect of AEC Waste Policies on Kuclear Industry," presented at AIF Meeting, Bal Harbour, Florida, October 18, 1971.

2 WASH-1327, "Generic Environmental Statement on the Use of Recycle Plutonfum in Mixed Oxide Fuel in LWR" (GESMO), USAEC, August 1974.

3 B L Cohen, "The Hazards in Plutonium Dispersal," Insticute for Energy Analysis, Oak Ridge, Tennessee, March 1975.

4 R J Cholister et al, "Nuclear Fuel Cycle Closure Alternatives," Allied-General Nuclear Services, Barnwell, SC. September 1975 (in press). 


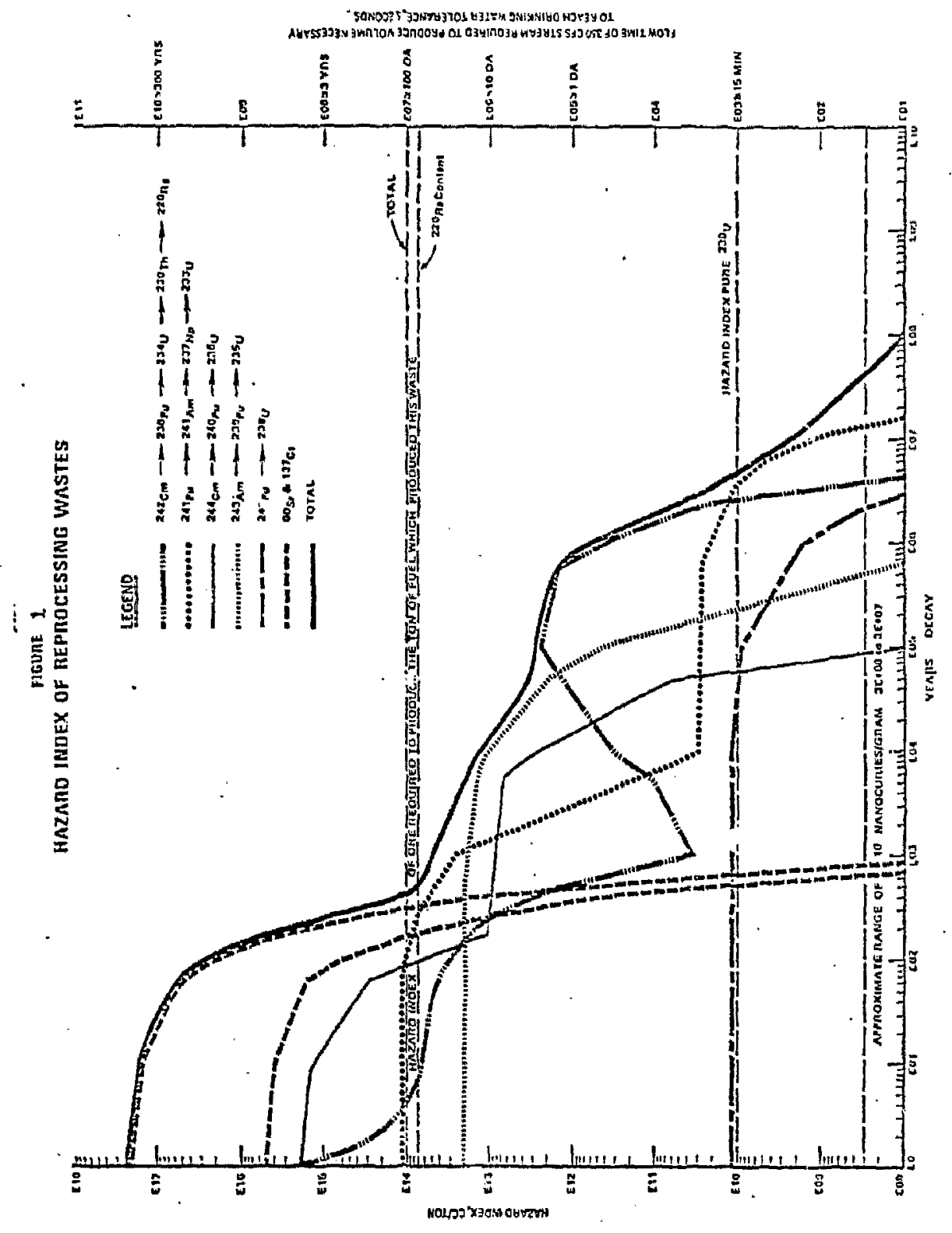




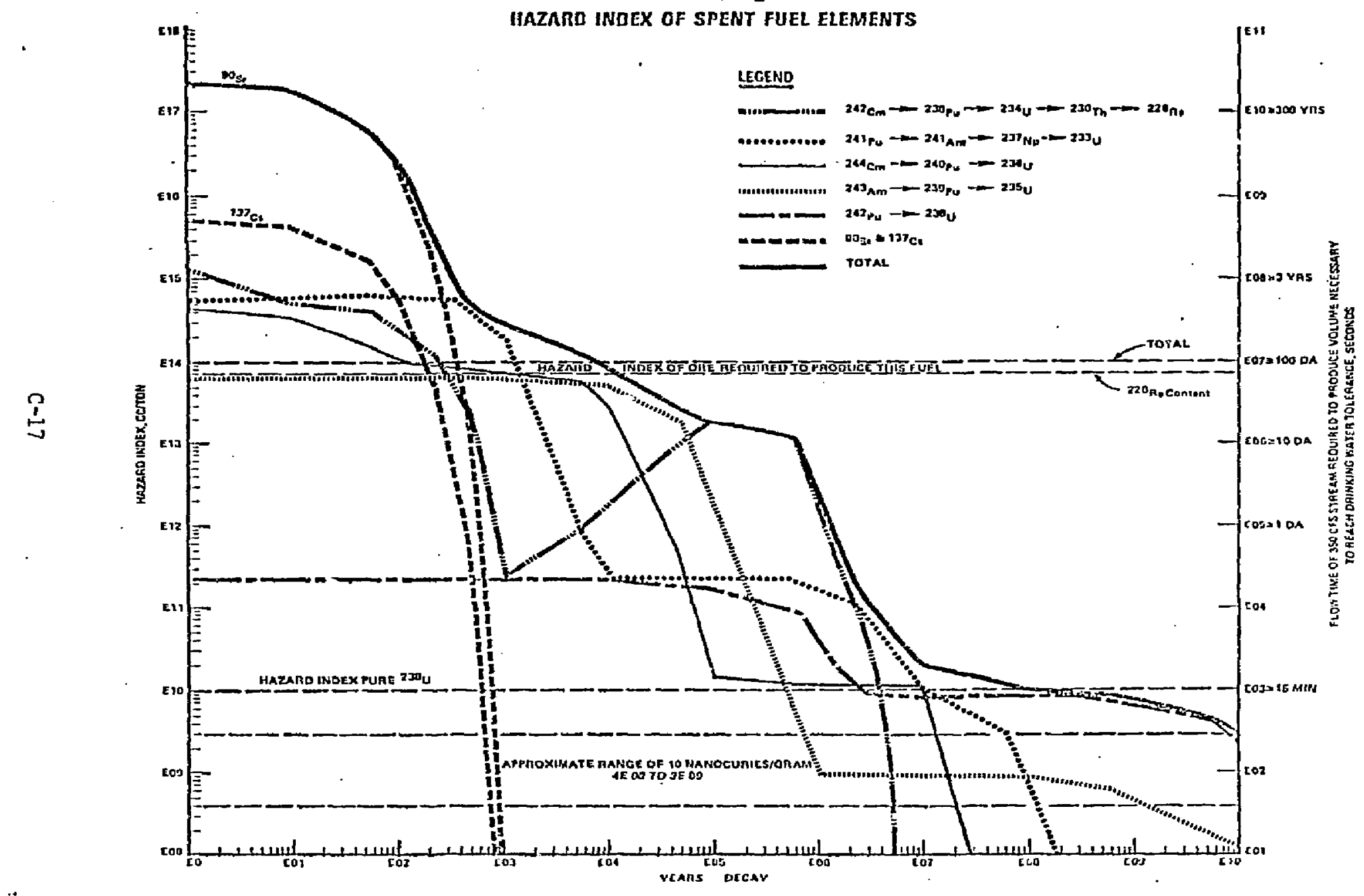




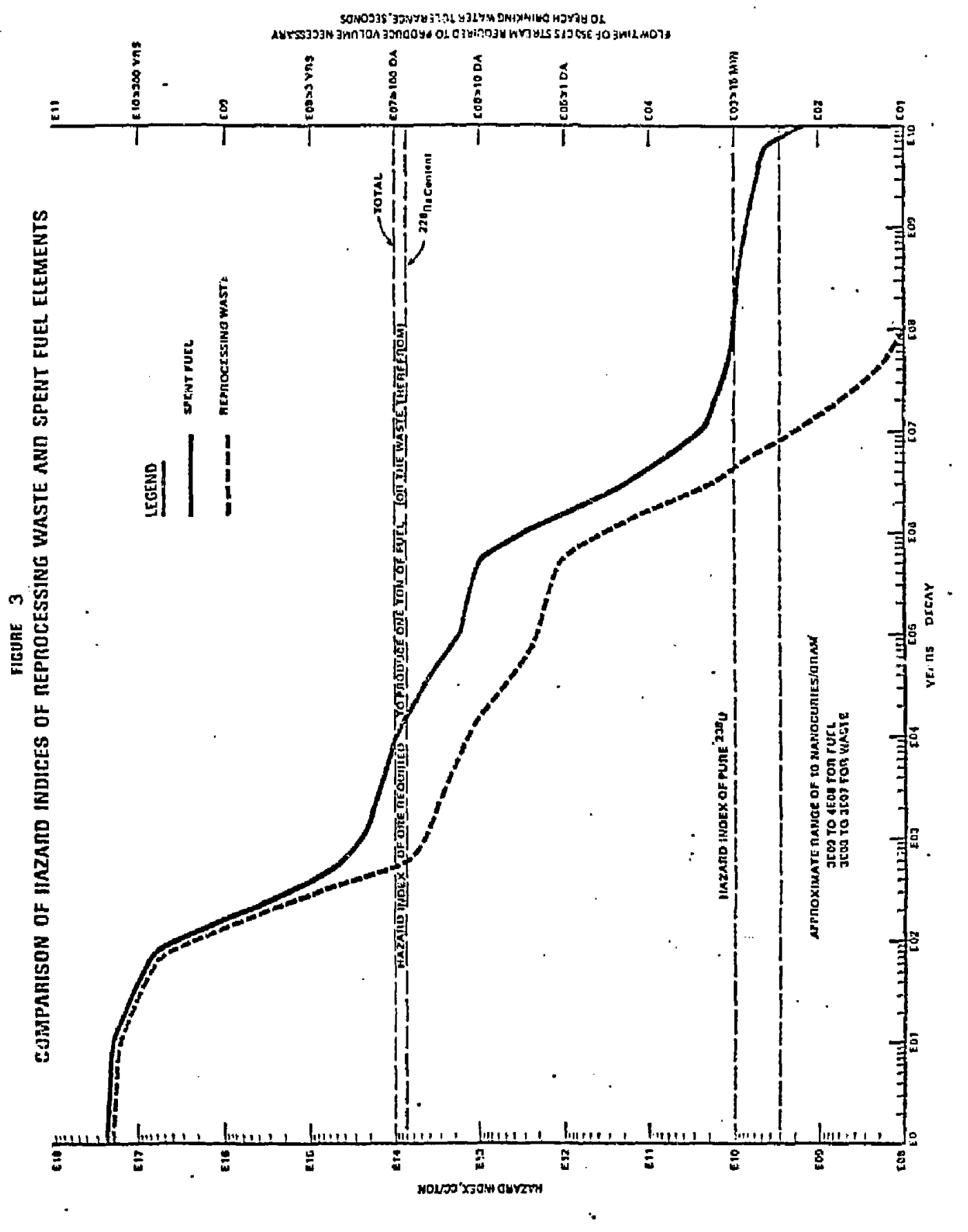




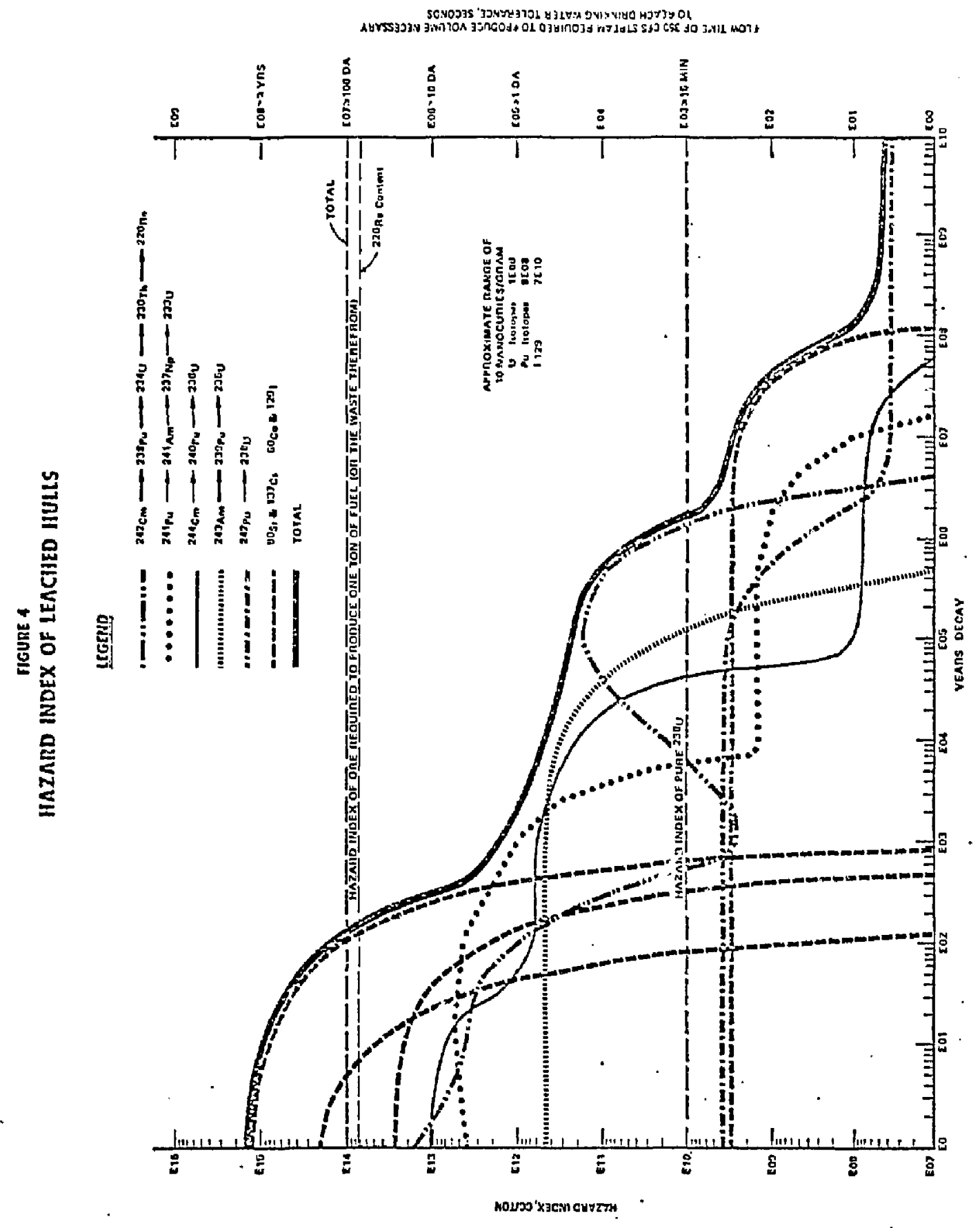


Table 1 (cont)

pase 2 of 3

Hazard Index of Hastas fron Reprocegsing

\begin{tabular}{|c|c|c|c|c|c|c|c|c|c|c|c|c|}
\hline & 500 yrs & 1000 yra & 5000 yтs & 10,000 yrs & 50,000 yra & 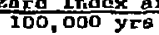 & $\frac{a x \text { Dacay }}{500,000 \text { yz }}$ & $\frac{\operatorname{conne}}{1,000,000 y r s}$ & $2,000,000$ yrs & $3,000,000 y \times 8$ & $4,050,000 y r s$ & $5,000,000 y r$ \\
\hline 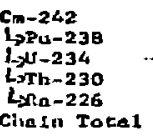 & $\begin{array}{r}1.2 E+12 \\
3.8 E+09 \\
1.9 E+08 \\
1.1 E+09 \\
1.2 E+12\end{array}$ & $\begin{array}{l}2.1 E+10 \\
3.0 E+09 \\
4.4 E+09 \\
4.9 E+09 \\
3.0 E+10\end{array}$ & $\begin{array}{c}E \\
3.8 E+09 \\
2.4 E+09 \\
9.3 E+10 \\
9.9 E+10\end{array}$ & $\begin{array}{c}E \\
3.7 E+09 \\
4.7 E+09 \\
2.4 E+12 \\
2.5 E+11\end{array}$ & $\begin{array}{c}E \\
3.3 \mathrm{E}+09 \\
1.9 \mathrm{E}+10 \\
\frac{1.2 \mathrm{E}+2.2}{1.2 \mathrm{E}+12}\end{array}$ & $\begin{array}{c}- \\
2.9 \bar{E}+09 \\
2.9 \mathrm{E}+10 \\
\frac{1.9 \mathrm{E}+12}{1.9 \mathrm{E}+12}\end{array}$ & $\begin{array}{c}E \\
2.5 E+08 \\
2.0 E+10 \\
\frac{1.3 F+12}{1.4 E+12}\end{array}$ & $\begin{array}{c}E \\
2.3 E+08 \\
5.2 E+09 \\
\frac{3.5 E+11}{3.5 E+11}\end{array}$ & $\begin{array}{c}\overline{-} \\
1.4 E+07 \\
3-2 E+08 \\
\frac{2-1 E+10}{2-1 E+10}\end{array}$ & $\begin{array}{c}E \\
0.5 E+05 \\
1.9 E+07 \\
1.3 E+09 \\
\frac{1.3 E+09}{3}\end{array}$ & $\begin{array}{c}- \\
5.2 E+04 \\
1.1 E+06 \\
7.7 E+07 \\
7 . E E+07\end{array}$ & $\begin{array}{c}\overline{-} \\
3.1 E+03 \\
7.0 E+04 \\
4.7 E+06 \\
4.7 E+05\end{array}$ \\
\hline $\begin{array}{l}\text { Pu-241 } \\
\text { LAnn-241 } \\
\text { Litp-237 } \\
\text { LL-233 } \\
\text { Citilin Total }\end{array}$ & $\begin{array}{l}4.2 E+01 \\
4.8 E+13 \\
1.5 E+10 \\
1.8 E+06 \\
4.8 E+13\end{array}$ & $\begin{array}{l}2 . \bar{E}+13 \\
2.3 E+10 \\
6.0 E+06 \\
2.3 E+13\end{array}$ & $\begin{array}{l}5.4 E+10 \\
2.9 E+10 \\
5.4 E+07 \\
8.4 E+10\end{array}$ & $\begin{array}{c}2 . \\
2.8 E+07 \\
2.9 E+10 \\
1.1 E+08 \\
3.0 E+10\end{array}$ & $\begin{array}{c}\overline{-} \\
2.9 E+10 \\
\frac{5.5 \mathrm{~F}+0 \mathrm{~B}}{3.0 \mathrm{E}+10}\end{array}$ & $\begin{array}{c}\overline{-} \\
2.8 E+10 \\
\frac{1,0 E+09}{3.0 E+10}\end{array}$ & $\begin{array}{c}\overline{-} \\
2.5 E+10 \\
\frac{2.3 E+09}{2.8 E+10}\end{array}$ & $\begin{array}{c}E \\
2.1 E+10 \\
\frac{2.2 E+09}{2.4 E+10}\end{array}$ & $\begin{array}{c}\overline{-} \\
1.5 E+10 \\
\frac{1.7 E+0 g}{1.7 E+10}\end{array}$ & $\begin{array}{c}\bar{E} \\
1.1 E+10 \\
\frac{1.2 E+09}{1.3 E+10}\end{array}$ & 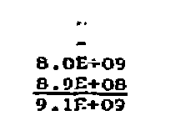 & $\begin{array}{c}\bar{E} \\
5.8 E+09 \\
\frac{6.3 E+08}{6.6 E+09}\end{array}$ \\
\hline 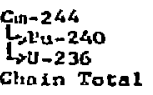 & $\begin{array}{l}5.7 E+06 \\
\text { a. } 9 E+12 \\
6.3 E+07 \\
B .9 E+12\end{array}$ & $\begin{array}{l}\frac{E}{8+5 E+12} \\
\frac{B-4 E+07}{B+5 E+12}\end{array}$ & $\begin{array}{c}5.6 \bar{E}+12 \\
2.2 E+08 \\
5.6 E+12\end{array}$ & $\begin{array}{c}\frac{-}{3.3 Z+12} \\
\frac{3.2 E+08}{3.3 E+12}\end{array}$ & $\begin{array}{l}4.9 E+10 \\
\frac{4.7 E+02}{4.9 E+10}\end{array}$ & $\begin{array}{l}2.5 \bar{E}+08 \\
\frac{4.7 E+03}{7.2 E+08}\end{array}$ & $\frac{E}{4.7 E+08}$ & $\frac{E}{\frac{5.6 \mathrm{E}+08}{4.6 \mathrm{E}+08}}$ & $\frac{\overline{-}}{4.5 E+08}$ & $\frac{\bar{E}}{\frac{4.3 E+0 b}{4.3 E+0 B}}$ & $\frac{\overline{-}}{4.2 \bar{E}+08}$ & $\frac{\bar{E}}{\frac{4 \cdot 1 \bar{E}+08}{4 \cdot 1 E+0 a}}$ \\
\hline 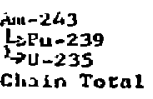 & $\begin{array}{l}1.7 E+13 \\
1.2 E+12 \\
3.0 E+06 \\
1.9 E+13\end{array}$ & $\begin{array}{l}1.6 E+13 \\
1.4 E+12 \\
\frac{3.1 E+06}{1.8 E+13}\end{array}$ & $\begin{array}{l}1.1 E+13 \\
2.4 E+12 \\
4.4 E+06 \\
1.4 E+13\end{array}$ & $\begin{array}{l}7.3 E+12 \\
3.0 E+12 \\
6.6 E+16 \\
1.1 E+13\end{array}$ & $\begin{array}{l}2 \cdot 2 E+11 \\
1.8 E+12 \\
2 \cdot f_{1}+07 \\
2.0 E+12\end{array}$ & $\begin{array}{l}2.9 E+09 \\
4.5 E+11 \\
3.2 E+07 \\
4.6 E+11\end{array}$ & $\begin{array}{l}5.3 E+06 \\
\frac{3.5 E+07}{4.05+07}\end{array}$ & $\frac{\bar{z}}{3.5 \overrightarrow{5}+07}$ & $\begin{array}{c}\bar{E} \\
\frac{3.5 \bar{E}+07}{3.5 E+07}\end{array}$ & $\begin{array}{c}\overline{-} \\
\frac{3.5 \bar{E}+07}{3.5 E+07}\end{array}$ & $\frac{\bar{s}}{3.5 \bar{E}+07}$ & $\frac{\overline{-}}{3.5 \bar{E}+07}$ \\
\hline $\begin{array}{l}P_{u-242} \\
\mathrm{~L}_{>U-238} \\
\text { Clu in Total }\end{array}$ & $\begin{array}{l}1.1 E+10 \\
\frac{4.3 E+107}{1.1 E+10}\end{array}$ & $\begin{array}{l}1.1 E+10 \\
4.3 E+07 \\
1.1 E+10\end{array}$ & $\begin{array}{l}1.1 E+10 \\
4.3 E+07 \\
1+1 E+10\end{array}$ & $\begin{array}{l}1.1 E+10 \\
\frac{4.3 E+Q 7}{3.1 E+20}\end{array}$ & $\begin{array}{l}9.9 E+09 \\
\frac{4.3 E+07}{9.9 E+09}\end{array}$ & $\begin{array}{l}9.05+09 \\
\frac{4.3 E+07}{9.0 E+09}\end{array}$ & $\begin{array}{l}4.3 E+09 \\
\frac{4.3 E+07}{4.3 E+09}\end{array}$ & $\begin{array}{l}1.7 E+09 \\
\frac{4.3 E+07}{1.4 E+013}\end{array}$ & $\begin{array}{l}2.0 E+08 \\
\frac{4.3 E+07}{3.2 E+0 B}\end{array}$ & $\begin{array}{l}4.5 E+07 \\
\frac{4.3 E+07}{8.7 E+07}\end{array}$ & $\begin{array}{l}7.2 E+06 \\
\frac{4.3 E+07}{5.0 E+07}\end{array}$ & $\begin{array}{l}7,2 E+06 \\
\frac{4.3 E+07}{4.4 E+07}\end{array}$ \\
\hline
\end{tabular}


Ilazard Index of Wastes from :eprocessing

Isotope

\section{Cm-242}

$\rightarrow \mathrm{Pu}-238$

LoU -234

LTh -230

$\longrightarrow R A-226$

Ghain Total

Pu-241

$4 \mathrm{Am}-241$

$\rightarrow N_{P}-237$

LU-233

Chain TotaI

$\mathrm{Cm}-244$

$\longrightarrow P u-240$

cluein Total

$A m-243$
$\mathrm{~L}=239$
$\mathrm{~L}-235$

$\mathrm{L} \mathrm{U}-235$

Pu-242

$4 \mathrm{U}-238$

Cha1n Total

ransuranic

Total

Sx -90

Cs -137

Total Sr\&Cs

TOTAL

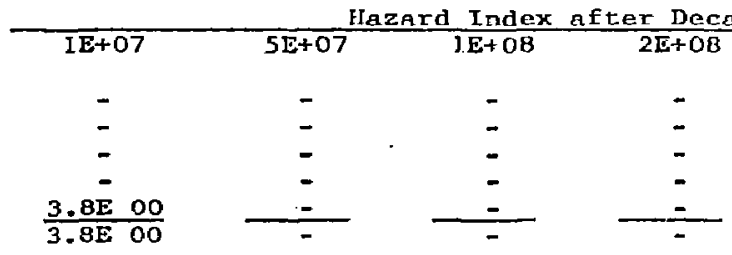

$1,2 \bar{E}+09$

$1.2 \mathrm{E}+08$

$\frac{1.2 \mathrm{E}+08}{\mathrm{I} .3 \mathrm{E}+0.9}$

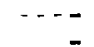

3. $5 \mathrm{E}+08$

$3.5 \mathrm{E}+08$

\section{2. $\bar{E}+$}

$\frac{3.0 E+02}{3.1 E+03}$
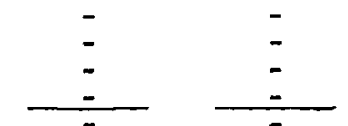

$\overline{-}$

1. $1 E+08$

1. $1 \mathrm{E}+08$

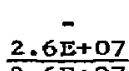

$\frac{2.6 E+07}{2.6 E+07}$

$-$

3. $3 \mathrm{E}+07$

$\frac{3.3 E+07}{3.3 E+07}$

$\frac{3 .}{2 E+07}$

2. $\overline{-}+07$

$2.9 \mathrm{E}+07$

$2 \bar{E}+07$

$\frac{4.2 E+07}{4.2 E+07}$

$4.2 \overline{\mathrm{E}}+07$

$\frac{4.1 E+07}{4.1 E+07}$

1. $9 E+O B$

$1 . \mathrm{OF}+\mathrm{OB}$

$7.1 \mathrm{E}+07$

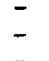

$-$

1. 7E+09

$\frac{4.3 E+07}{4.3 E+07}$

-

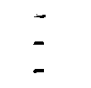

$1.0 E+08$

7. 1E+07
4.1E+07

$3 E+08$

$4 E+O B$

$5 \mathrm{E}+08$
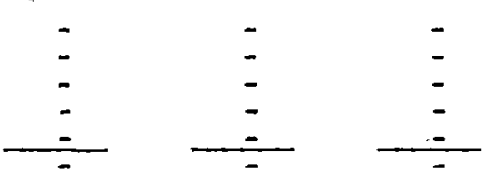
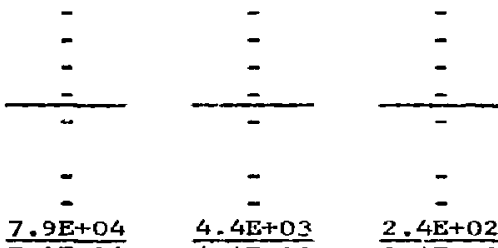

$4.4 \bar{E}+03$

$\frac{4.4 E+03}{4.4 E+03}$

$2.4 \bar{E}+02$

$7.9 \mathrm{E} \div 04$

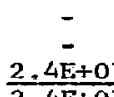

$2.4 \mathrm{E}+02$

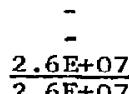

$\frac{2.4 E+07}{2.4 E+07}$

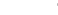

2. $1 \mathrm{E}+07$

-

4. $\overline{0 E+07}$

$3.9 \overline{\mathrm{E}}+07$

6. $? \mathrm{E}+07$

$6.4 \mathrm{E}+07$

$6.0 E+07$

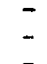

$.7 \mathrm{E}+\mathrm{C} 7$

6. $0 \mathrm{E}+07$ $\frac{4.1 E+07}{4.1 E+07} \quad \frac{4.0 E+07}{4.0 E+07} \quad \frac{3.9 E+07}{3.9 F+07}$ 
page 1 of 2

Hazard Index of Spent Fuel Elementa Treated as Haste

\begin{tabular}{|c|c|c|c|c|c|c|c|c|c|c|c|c|c|}
\hline Igotope & $\begin{array}{l}\text { Imatopic } \\
\text { Content } \\
\text { curieg/tannea }\end{array}$ & $\begin{array}{l}\text { Half-Iife } \\
\text { year }\end{array}$ & yent $^{\lambda}-1$ & $\underset{\text { pe/ce }}{\operatorname{MPC}}$ & $\begin{array}{l}\text { Hazard } \\
\text { Index } \\
\text { ceftonne }\end{array}$ & $10 \overline{y 00 x A}$ & 50 years & 100 yeats & yeats & $\frac{x \text { Decny, }}{300 \text { years }}$ & $\frac{\text { tonne }}{\text { Ato Yesra }}$ & So0 years & 1000 years \\
\hline 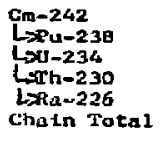 & $\begin{array}{c}1.73 E+04 \\
2.88 E+03 \\
= \\
=\end{array}$ & $\begin{array}{c}0.5 \\
90 \\
2.5 \mathrm{E}+05 \\
8.0 \mathrm{E}+04 \\
2.52 \mathrm{E}+03\end{array}$ & $\begin{array}{c}1.55 \\
7.7 E-03 \\
2.8 E-06 \\
8.7 E-05 \\
4.3 E-04\end{array}$ & $\begin{array}{l}2 E-05 \\
5 E-06 \\
3 E-05 \\
2 E-06 \\
3 E-08\end{array}$ & $\begin{array}{c}8.78+14 \\
5.8 E+14 \\
\vdots \\
\overline{-} \\
1.4 \mathrm{E}+15\end{array}$ & $\begin{array}{l}1.6 E+08 \\
5.5 E+14 \\
2.7 E+09 \\
1.7 E+06 \\
1.7 E+05 \\
\frac{5.5 E+14}{4}\end{array}$ & $\begin{array}{l}4.0 E+14 \\
1.1 E+10 \\
4.0 E+07 \\
2.0 E+07 \\
4.0 E+14\end{array}$ & $\begin{array}{l}2.7 \bar{E}+14 \\
1.9 E+10 \\
1.4 E+0 Q \\
\frac{1.4 E+0 B}{2.7 \overline{1} L_{4}}\end{array}$ & $\begin{array}{l}1.2 \bar{E}+14 \\
2.0 E+10 \\
4.5 E+0 a \\
9.5 E+08 \\
1.2 E+14\end{array}$ & $\begin{array}{l}5.3 E+13 \\
3.1 E+10 \\
8.4 E+08 \\
2.7 E+09 \\
5.3 E+13\end{array}$ & $\begin{array}{l}2.4 E+13 \\
3.3 E+10 \\
1.3 E+09 \\
5.5 E+09 \\
2.2 E+13\end{array}$ & $\begin{array}{l}1.1 \overline{1 E+13} \\
3.4 E+10 \\
1.7 E+09 \\
\frac{9.5 E+09}{1.1 E+13}\end{array}$ & $\begin{array}{l}1.9 E+11 \\
3.4 \mathrm{E}+10 \\
3.9 \mathrm{E}+09 \\
4.4 \mathrm{E}+10 \\
\frac{2.7 \mathrm{E}+11}{4}\end{array}$ \\
\hline 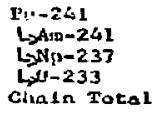 & $\begin{array}{c}1.02 E+05 \\
1.67 \mathrm{0}+02 \\
-\end{array}$ & $\begin{array}{l}13 \\
4.58 E+02 \\
2.208+06 \\
1.60 E+05\end{array}$ & $\begin{array}{r}5.3 \mathrm{E}-02 \\
1.51 \mathrm{E}-03 \\
3.15 \mathrm{E}-07 \\
4.33 \mathrm{E}-06\end{array}$ & $\begin{array}{l}2 E-04 \\
4 E-06 \\
3 E-06 \\
3 E-05\end{array}$ & $\begin{array}{c}5.1 E+14 \\
4.2 E+13 \\
\bar{E} \\
5.5 E+14\end{array}$ & $\begin{array}{l}3.0 E+14 \\
3.4 E+14 \\
8.8 \%+08 \\
1.4 E+0 I \\
6.4 E+14\end{array}$ & $\begin{array}{l}3.7 E+13 \\
6.9 E+14 \\
1 \cdot 2 E+10 \\
\frac{9}{7}=\frac{3 E+104}{2 E+14}\end{array}$ & $\begin{array}{l}2.6 E+12 \\
6.8 E+14 \\
2.6 E+10 \\
4.8 E+0.5 \\
6.9 E+14\end{array}$ & $\begin{array}{l}1.4 E+10 \\
5.9 E+14 \\
5.3 E+10 \\
2.2 E+06 \\
5.5 E+14\end{array}$ & $\begin{array}{l}7.4 E+07 \\
5.1 E+14 \\
7.7 E+10 \\
5.08+0.6 \\
5.1 E+14\end{array}$ & $\begin{array}{l}3.9 E+05 \\
4.4 E+14 \\
9.7 E+10 \\
\frac{8.7 E+0.5}{4.4 E+14}\end{array}$ & $\begin{array}{l}2.1 E+03 \\
3.7 E+14 \\
1.1 E+11 \\
1.3 E+07 \\
3.7 E+14\end{array}$ & $\begin{array}{l}1 . \\
1.0 E+14 \\
1.7 E+21 \\
\frac{4.5 E+07}{1.8 E+14}\end{array}$ \\
\hline $\begin{array}{l}\text { Gin-244 } \\
1>P u-240 \\
1 \text { Is-236 } \\
\text { Eliain Total }\end{array}$ & $\begin{array}{l}2.54 E+03 \\
4.73 E+02 \\
2.50 E-01\end{array}$ & $\begin{array}{l}18 \\
6.6 \mathrm{E}+03 \\
2.4 \mathrm{E}+07\end{array}$ & $\begin{array}{l}3.85 E-02 \\
1.05 E-04 \\
2.90 E-08\end{array}$ & $\begin{array}{l}7 E-06 \\
5 E-06 \\
3 E-05\end{array}$ & $\begin{array}{l}3.6 \mathrm{E}+14 \\
9.5 \mathrm{E}+13 \\
0.3 \mathrm{E}+09 \\
4.6 \mathrm{E}+14\end{array}$ & $\begin{array}{l}2 \cdot 4 \mathrm{E}+1 / \\
9 \cdot 5 \mathrm{E}+13 \\
\frac{\mathrm{B}}{3.3 \mathrm{E}+09} \\
.4 \mathrm{E}+14\end{array}$ & $\begin{array}{l}5.1 E+13 \\
9.5 E+13 \\
8.4 E+99 \\
1.5 E+14\end{array}$ & $\begin{array}{l}7.1 E+12 \\
9.5 E+13 \\
0.4 E+09 \\
1.0 E+14\end{array}$ & $\begin{array}{l}1.4 E+11 \\
9.4 E+13 \\
\frac{0.4 E+09}{9.4 E+13}\end{array}$ & $\begin{array}{l}2.7 E+09 \\
9.3 E+13 \\
8.5 E+09 \\
9.3 E+13\end{array}$ & $\begin{array}{l}5.3 E+07 \\
9.2 E+i 3 \\
6.5 E+09 \\
9.2 E+11\end{array}$ & $\begin{array}{l}1.0 E+06 \\
9.1 E+13 \\
\frac{\theta .6 E+09}{9.1 E+13}\end{array}$ & $\begin{array}{l}6.6 \bar{E}+13 \\
\frac{8.8 E+09}{8.6 E+13}\end{array}$ \\
\hline 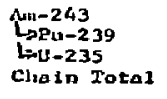 & $\begin{array}{l}1.80 E+01 \\
3.23 E+02 \\
1.75 E-02\end{array}$ & $\begin{array}{r}0.0 E+03 \\
2.4 .3 E+04 \\
7 E+08\end{array}$ & $\begin{array}{r}\text { 8.7E-05 } \\
2.85 E-05 \\
9.9 E-10\end{array}$ & $\begin{array}{l}\text { 4E-OG } \\
\text { SE-OS } \\
\text { 3E-OS }\end{array}$ & $\begin{array}{l}4.5 E+12 \\
6.5 E+13 \\
5.8 E+0.8 \\
6.9 E+13\end{array}$ & $\begin{array}{l}4.515+12 \\
6.5 E+13 \\
5 . . a E+08 \\
6.35+13\end{array}$ & $\begin{array}{l}4.5 E+12 \\
6.5 I+13 \\
5.8 E+08 \\
6.9 E+13\end{array}$ & $\begin{array}{l}4.5 E+12 \\
6.4 E+13 \\
5.8 E+08 \\
6.9 E+13\end{array}$ & $\begin{array}{l}4.4 E+12 \\
6.4 E+13 \\
5.9 E+08 \\
6.9 E+13\end{array}$ & $\begin{array}{l}4.4 E+12 \\
6.4 E+13 \\
5.9 E+0 B \\
6.9 E+13\end{array}$ & $\begin{array}{l}4.3 E+12 \\
6.4 E+13 \\
5.9 E+0 B \\
6.8 E+13\end{array}$ & $\begin{array}{l}4.3 E+12 \\
6.4 E+13 \\
\frac{5.9 E+09}{6 \cdot 8 E+13}\end{array}$ & $\begin{array}{l}4.1 E+12 \\
6.3 E+13 \\
5,9 E+08 \\
6.7 E+13\end{array}$ \\
\hline $\begin{array}{l}\text { Pu-242 } \\
\text { LU-238 } \\
\text { Cliain Total } \\
\text { Pransurante }\end{array}$ & $\begin{array}{r}1.00 E 00 \\
3.33 E-01\end{array}$ & $\begin{array}{l}3.0 E+05 \\
4.5 \mathrm{E}+09\end{array}$ & $\begin{array}{l}1.82 E-06 \\
1.54 \mathrm{E}-10\end{array}$ & $\begin{array}{l}\text { SE-06 } \\
4 E-05\end{array}$ & $\begin{array}{l}2.0 E+11 \\
\frac{0.3 E+09}{2.1 E+11}\end{array}$ & $\begin{array}{l}\frac{2.0 E+11}{8.3 E+0 g} \\
\frac{2.1 E+11}{1 E+1}\end{array}$ & $\begin{array}{l}2.0 z+11 \\
\frac{a .3 E+09}{2.1 E+11}\end{array}$ & $\begin{array}{l}2.0 E+11 \\
\frac{g .3 E+09}{2.1 E+11}\end{array}$ & $\begin{array}{l}2.0 E+11 \\
\frac{0,3 E+0.9}{2.1 E+11}\end{array}$ & $\begin{array}{l}2.0 E+1 I \\
\frac{B .3 E+09}{2.1 E+11}\end{array}$ & $\begin{array}{l}2.0 E+11 \\
\frac{B \cdot 3 E+09}{2.1 E+11}\end{array}$ & $\begin{array}{l}2.0 E+11 \\
E .3 E+09 \\
2.1 E+11\end{array}$ & $\begin{array}{l}2.0 E+11 \\
\frac{8.3 E+09}{2.1 E+1.1}\end{array}$ \\
\hline $\begin{array}{l}\text { Total } \\
\text { sc }-90 \\
\text { Cs-137 } \\
\text { lotn1 GsESr }\end{array}$ & $\begin{array}{l}7.60 \mathrm{0E}+04 \\
1.07 \mathrm{E}+05\end{array}$ & $\begin{array}{l}28 \\
30\end{array}$ & $\begin{array}{l}2.4 \mathrm{E}-02 \\
2.3 \mathrm{E}-02\end{array}$ & $\begin{array}{l}3 E-07 \\
2 E-0 S\end{array}$ & $\begin{array}{l}2.5 E+15 \\
2.5 E+17 \\
5.4 E+15 \\
2.6 E+17\end{array}$ & $\begin{array}{l}1.6 E+15 \\
2.0 E+17 \\
4.3 E+15 \\
2.1 E+17\end{array}$ & $\begin{array}{l}1.3 E_{0}+15 \\
7.6 E+16 \\
\frac{1.7 E+15}{9.0 E+16}\end{array}$ & $\begin{array}{l}1.1 E+15 \\
2.3 E+16 \\
5.3 E+14 \\
\frac{2.2 E+1.5}{2+5}\end{array}$ & $\begin{array}{l}8.7 E+14 \\
2.1 E+15 \\
5.3 E+13 \\
2.2 E+15\end{array}$ & $\begin{array}{l}7.3 E+14 \\
1.9 E+14 \\
5.2 E+12 \\
2.0 E+14\end{array}$ & $\begin{array}{l}6.25+14 \\
1.7 \mathrm{E}+13 \\
5.2 \mathrm{E}+1 \frac{1}{13} \\
1.8 \mathrm{E}+13\end{array}$ & $\begin{array}{l}5.4 E+14 \\
1.5 E+12 \\
5.2 E+10 \\
1.6 E+12\end{array}$ & $\begin{array}{l}3.3 E+14 \\
9.1 E+06 \\
5.0 E+05 \\
1.0 E+07\end{array}$ \\
\hline TOTAL & & & & & $2.6 E+17$ & $2,1 E+17$ & $-12+16$ & $5 E+16$ & 3. $1 E+15$ & $9.2 E+14$ & $6.4 \mathrm{E}+14$ & $5.4 E+14$ & $3.3 E+14$ \\
\hline
\end{tabular}




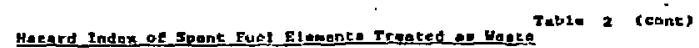

pere 2 or 2

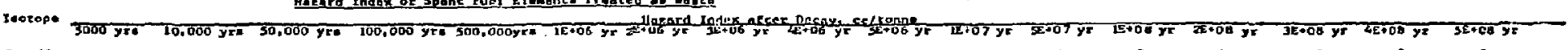

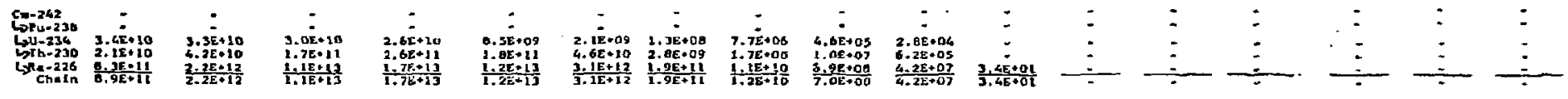

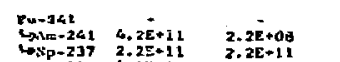
$\begin{array}{lll}2.28 .03 & \vdots & \vdots\end{array}$

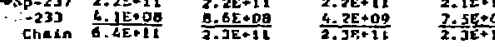

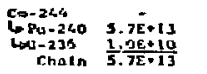
证:

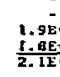

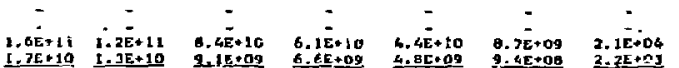
$\vdots \quad \vdots$

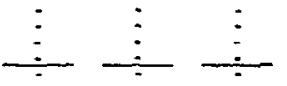

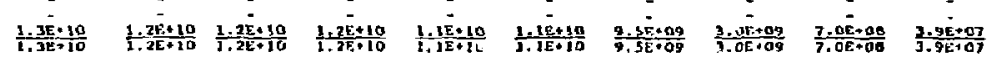

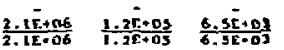

An:-263 $2.95 .12 \quad 1.5 \mathrm{E} \cdot 112$

3. $0 \mathrm{EE}+10 \quad 7.4 \mathrm{E}+0 \mathrm{~B}$

$0 .-233$
Cha in

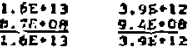

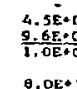

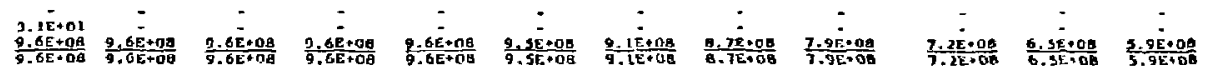

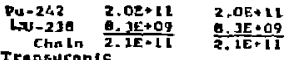

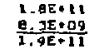

$\frac{1.35+11}{1.78+09}$

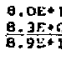

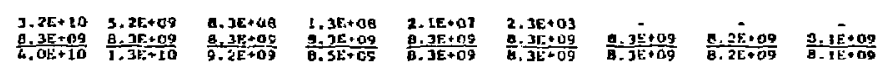

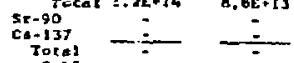

2.

2. $1 E+11$

$1.2 \mathrm{E} \cdot 13$

3. $3 \mathrm{E}+12$ 3. $5 \mathrm{E} \cdot 12$

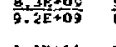

C.S55 $1.25: 40$

$0.89+13$

2. $8 \mathrm{~B}+13$

$2.12+13$

$1.25+83$

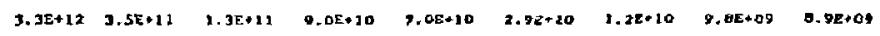

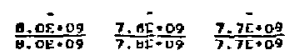

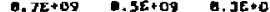

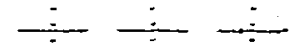

$0.75+02 \quad 0.5 E \cdot 09 \quad 8.35 \cdot 09$ 


\section{Notes for Table I}

a SAR West Valley Plant, Nuclear Fuel Services Docket 50-201, Table III-2-1

b $75 \% \mathrm{vO}_{2}$ fuel, $25 \%$ mixed oxide fuel

c 10CFR20, Appendix B

d Quantity of water required to dilute isotopic content to $\mathrm{MPC}$, sc/tonne

\section{Notes for Table 2}

a SAR West Valley Plant, Nuclear Fuel Services Docket 50-201, Table III-2-1

b 10CER20, Appendix B

c Quantity of water required to dilute isotopic content to $M P C$, cc/tonne 

Hazord Index af Hulls

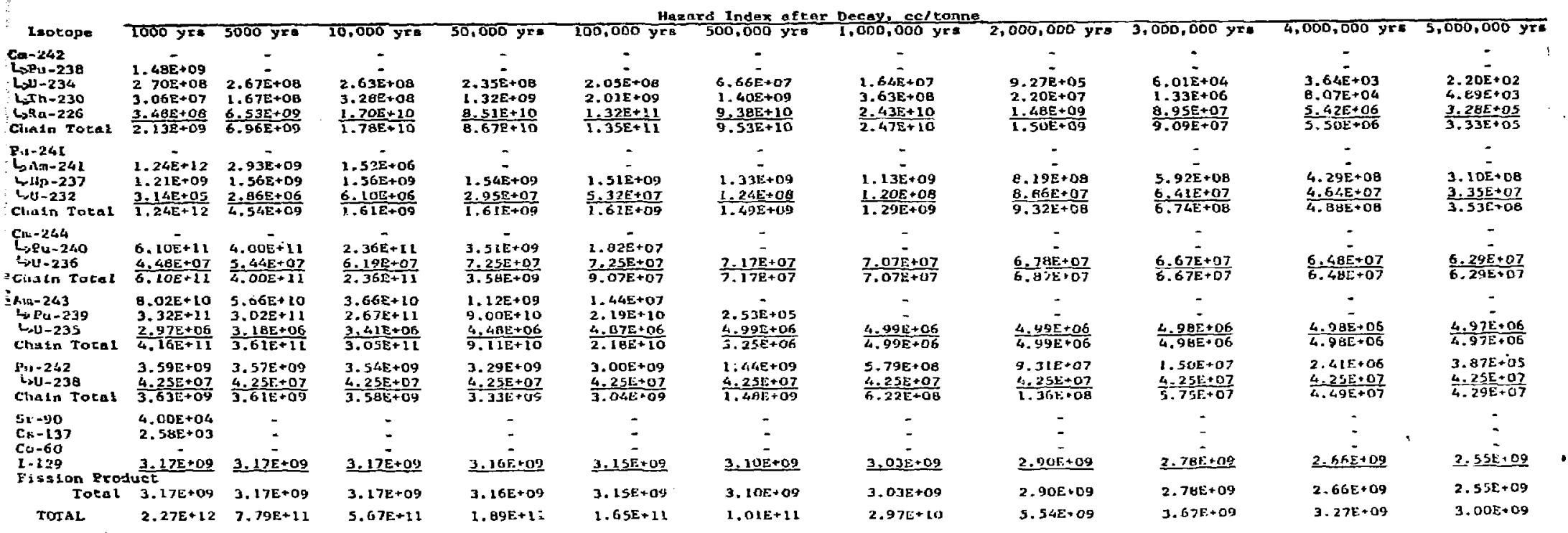


Table 3 : :ont)

page 3 of 3

Hazard Index of Iu 1 1E

$$
\text { Isotope }
$$

\section{Cm -242}

$\operatorname{cin}_{t \rightarrow-238}$

Lㄱ. -234

CTh-230

$\operatorname{li} R a-226$

Cliain Total

Pu-241

L,Am-241

$\rightarrow$ Np -237

LU-233

Chain Total

$\mathrm{Cm}-244$

$\longrightarrow$ Pu -240

Lل-236

Chain Total

Am-243

LPu-239

$L y-235$

Chain Tota 1

$\mathrm{Pu}-242$
$\rightarrow \mathrm{U}-238$

CU-238
Chain Total

Sr -90

Cs- 137

Co-60

I - 129

Fission Product

Total

TOTAL

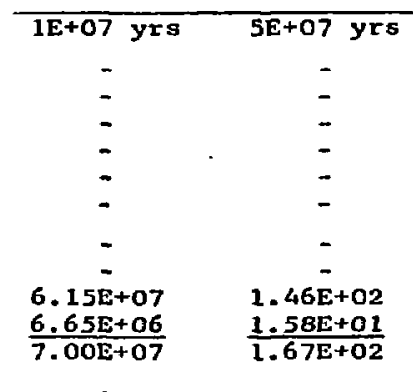

$5.45 \bar{E}+07$

$\frac{5.45 E+07}{5.45 \mathrm{E}+07}$

$-$

4. $95 \mathrm{E}+05$

$4.95 E+06$

4. $15 \mathrm{E}+01$

$4+24 E+07$

4. $24 E+07$

2. $05 E+09$

2. $05 E+09$

2. 22E+09

$\frac{1.71 \overline{\mathrm{E}}+07}{1.71 \bar{E}+07}$

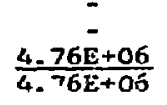

$\frac{4.22 \bar{E}+0 \%}{4.22 E+07}$

$3.64 E+08$

3. $64 \mathrm{E}+0 \mathrm{~B}$

4. $28 \mathrm{E}+08$
Hazard I

$\frac{x \text { after D }}{2 E+08 \text { yrs }}$
, ce/tonne

$\begin{array}{ccc}- & - & - \\ - & - & - \\ - & - & - \\ - & - & - \\ - & - & - \\ - & - & - \\ - & - & - \\ - & - & - \\ - & - & - \\ \frac{-}{4.01 E+06} & \frac{2.21 E+05}{2.21 E+05} & \frac{1.22 E+04}{1.22 E+04}\end{array}$

$1.71 \mathrm{E}+07 \quad 4.01 \mathrm{E}+06$
$-$

4. $53 \mathrm{E}+06$

$4.53 E+06$

$\frac{4.19 \bar{E}+07}{4.19 \bar{E}+07}$

\section{$2.21 E+05$}

$-$

4. 1 LE +06

4.11E+06

$\frac{4.12 \vec{E}+07}{4.12 E+07}$

4.17E+07

4. 17E+07

$9.20 E+O 7$

$5.50 E+0.5$

$5.50 \mathrm{E}+05$

$4.61 E+07$
1. $22 \mathrm{E}+04$

\section{3. $73 E+06$ \\ $3.73 E+06$}

$\frac{4.06 \bar{E}+07}{4.06 \mathrm{E}+07}$

7. $25 \mathrm{E}+03$

4. $43 \mathrm{E}+07$
$4 \mathrm{E}+08$ yrs

$5 E+08$ yrs

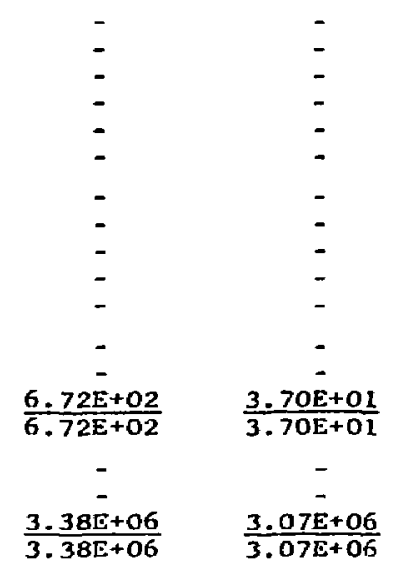

$\frac{4.00 \bar{E}+07}{4.00 \bar{E}+07} \quad \frac{3.94 \bar{E}+07}{3.94 \bar{E}+07}$

7. $25 \mathrm{E}+03$

$9.55 E+01$

I.26E 00

9. 55E+01

1. 26E 00

4. $34 E+07$

4. $25 E+07$ 
Table 4

Maximum Concentrations Expected

from On-Site Hull Burial

\section{Isotope}

Co-60

Sr -90

I -129

Cs-137

$\mathrm{Pu}-238$

$\mathrm{Pu}-239$

$\mathrm{Pu}-240$

$\mathrm{Pu}-241$

$\mathrm{Pu}-242$

Am-241

Am- 243

CTm-242

$\mathrm{Cm}-244$

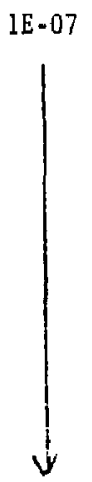

Mechanism 3

Total Inventory Mechanisms $1 \& 2$ after 30 yrs curies

Fraction Escape

at Discharge

Mechanism 4 Mechanisa 5

Decay

Conc in Stream $\mu c / c e$

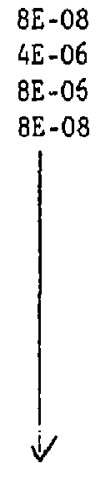

$7.2 \mathrm{E}+06$

5.7E 00

1. $2 \mathrm{E}+07$

$5.9 \mathrm{E}+05$

5. $1 E+04$

$9.6 \mathrm{E}+04$

$1.05 \mathrm{E}+07$

$5.4 E+02$

5. $1 E+04$

$1.05 E+04$

$1.65 \mathrm{E}+05$

$1.25 \mathrm{E}+06$
$E=100$

$E-100$

E-100

0.998

E- 100

E-100

1. $5 \mathrm{E}-20$

$E=100$

1. $6 \mathrm{E}-29$

$E=100$

E- 100

1. 4E-02

E- 100

2. $5 \mathrm{E}-89$

E-100

E-100

$-100$

2E-47

$E-100$

E- 100

$2 \mathrm{E}-22$

E-100

E-100

E-100

E-100 